\title{
Using long-term records to investigate watershed nitrogen supply and demand dynamics at the Fernow Experimental Forest, West Virginia, USA
}

Mark Benjamin Burnham

Follow this and additional works at: https://researchrepository.wvu.edu/etd

\section{Recommended Citation}

Burnham, Mark Benjamin, "Using long-term records to investigate watershed nitrogen supply and demand dynamics at the Fernow Experimental Forest, West Virginia, USA" (2017). Graduate Theses, Dissertations, and Problem Reports. 5284.

https://researchrepository.wvu.edu/etd/5284

This Dissertation is protected by copyright and/or related rights. It has been brought to you by the The Research Repository @ WVU with permission from the rights-holder(s). You are free to use this Dissertation in any way that is permitted by the copyright and related rights legislation that applies to your use. For other uses you must obtain permission from the rights-holder(s) directly, unless additional rights are indicated by a Creative Commons license in the record and/ or on the work itself. This Dissertation has been accepted for inclusion in WVU Graduate Theses, Dissertations, and Problem Reports collection by an authorized administrator of The Research Repository @ WVU.

For more information, please contact researchrepository@mail.wvu.edu. 


\title{
Using long-term records to investigate watershed nitrogen supply and demand dynamics at the Fernow Experimental Forest, West Virginia, USA
}

\author{
Mark Benjamin Burnham
}

Dissertation submitted to the Eberly College of Arts and Sciences at West Virginia University

in partial fulfillment of the requirements for the degree of

Doctor of Philosophy in Biology

William Peterjohn, Ph.D., Chair

Richard Thomas, Ph.D.

James McGraw, Ph.D.

Mary Beth Adams, Ph.D.

Jonathan Cumming, Ph.D.

Department of Biology

Morgantown, West Virginia

2017

Keywords: Temperate deciduous forest; nitrogen; aluminum; ${ }^{15} \mathrm{~N}$ isotope; tree rings Copyright 2017 Mark Burnham 


\begin{abstract}
Using long-term records to investigate watershed nitrogen supply and demand dynamics at the Fernow Experimental Forest, West Virginia, USA
\end{abstract}

\title{
Mark Benjamin Burnham
}

Fossil fuel combustion has caused elevated anthropogenic nitrogen $(\mathrm{N})$ deposition onto forests in the northeastern United States since the middle of the $20^{\text {th }}$ century, and has resulted in the supply of $\mathrm{N}$ exceeding the ecosystem $\mathrm{N}$ demand in many forests across the region. While the supplydemand imbalance is often attributed to elevated $\mathrm{N}$ inputs, a reduction in $\mathrm{N}$ demand may also make a significant contribution to diminished levels of $\mathrm{N}$ retention. Long-term records of $\mathrm{N}$ inputs, outputs, and stand dynamics at the Fernow Experimental Forest (FEF) in Tucker County, $\mathrm{WV}$, provide a unique opportunity to study how changes in ecosystem demand can influence $\mathrm{N}$ retention. The long-term data at the FEF has also allowed me to assess whether changes in $\mathrm{N}$ retention are accurately recorded in the stable isotope record of tree rings. If the isotopes in tree rings prove to be a suitable index of $\mathrm{N}$ retention, then it would be possible to expand the temporal and spatial extent of existing records of forest $\mathrm{N}$ dynamics.

In this dissertation, I examine how forest species composition and soil acidity affect stand $\mathrm{N}$ supply and demand, and evaluate the use of tree ring $\delta^{15} \mathrm{~N}$ as an indicator and recorder of temporal changes in $\mathrm{N}$-saturation. In Chapter 1, I introduce $\mathrm{N}$ supply and demand dynamics in the FEF, and describe the study areas used to investigate both stand $\mathrm{N}$ demand and the usefulness of tree ring $\delta^{15} \mathrm{~N}$ as a recorder of $\mathrm{N}$ cycling. In Chapter 2, I used long-term records of stand composition and measurements of tree $\mathrm{N}$ uptake to determine if a shift in species composition reduced stand $\mathrm{NO}_{3}$ demand, resulting in an increase in stream $\mathrm{NO}_{3}$ discharge. Stand $\mathrm{NO}_{3}$ demand did not decline with a change in species composition, but soil $\mathrm{NO}_{3}$ supply likely increased, contributing to greater levels of $\mathrm{NO}_{3}$ loss in stream water. In Chapter 3, I measured the effect of experimental whole-watershed acidification on soil $\mathrm{Al}^{3+}$ solubility, and evaluated whether elevated $\mathrm{Al}^{3+}$ affected the relative uptake of $\mathrm{NH}_{4}$ and $\mathrm{NO}_{3}$ by trees. My results showed that elevated soluble $\mathrm{Al}^{3+}$ in the soil reduces tree $\mathrm{NO}_{3}$ demand of several important species by shifting their mineral $\mathrm{N}$ uptake towards $\mathrm{NH}_{4}$, and that an increase of $\mathrm{Al}^{3+}$ in the soil of the acidified watershed may have increased stream water $\mathrm{NO}_{3}$ discharge by reducing stand $\mathrm{NO}_{3}$ demand. In Chapter 4, I examine how effectively the tree ring $\delta^{15} \mathrm{~N}$ of four tree species records an experimentally induced increase in stream-water $\mathrm{NO}_{3}$ that was caused by a large, one-time addition of urea. While three of the four species examined recorded the onset of the change in stream chemistry, each species differed in its sensitivity and duration of response, and the fourth species only responded to a later increase in baseline $\mathrm{N}$ discharge. In Chapter 5, I assess the ability of tree ring $\delta^{15} \mathrm{~N}$ of the same four tree species to respond to a greater soil $\mathrm{NO}_{3}$ supply and record the apparent onset of $\mathrm{N}$ saturation in an untreated reference watershed using soil nitrification measurements and long-term stream water $\mathrm{NO}_{3}$ records. Similar to the response to addition of urea, the results were mixed. The tree ring $\delta^{15} \mathrm{~N}$ of two species were associated with changes in $\mathrm{N}$ cycling and $\mathrm{NO}_{3}$ loss, and they varied in their sensitivity to $\mathrm{N}$-saturation. Finally, in Chapter 6 I show how long-term records at the FEF provide a unique opportunity to illustrate how ecosystem $\mathrm{N}$ demand interacts with $\mathrm{N}$ deposition trends to affect stream $\mathrm{NO}_{3}$ discharge. In 
considering both of my assessments of the potential usefulness of tree ring $\delta^{15} \mathrm{~N}$ records, I conclude that these records can provide opportunities to expand current $\mathrm{N}$ cycle records, but enough uncertainty remains to preclude their widespread application until we achieve a deeper understanding of the mechanisms that control wood N. Thus, continuous measurement records of $\mathrm{N}$ cycling remain paramount in elucidating $\mathrm{N}$ supply and demand dynamics. 


\section{Acknowledgements}

First and foremost, I thank Dr. Peterjohn, for your unwavering guidance throughout my time as your advisee. Your unique blend of knowledge, patience, enthusiasm, wit, and love for teaching science make you a truly outstanding advisor. I also thank all of my committee members for your guidance and input. In particular, I thank Dr. Cumming for your help with plant physiology and aluminum analysis; Dr. McGraw for your consistent guidance on teaching, writing, experimental design, and statistics; Dr. Adams for making the Fernow accessible and for your depth of knowledge of the field site; and Dr. Thomas for your career and life advice. I thank Dr. Karl McKnight for being an outstanding teacher and setting me on the path of biological and ecological research. I thank the Fernow Experimental Forest staff for their maintenance of the study site. For field and laboratory help, I thank the many Fernow Undergraduate Summer (and Fall-Spring) Interns, including Hannah Hedrick, Leah Baldinger, Rachel Arrick, Jessica Graham, Hoff Lindberg, Lillian Hill, Devon Raiff, Tyler Miller, and Justin Lego. Thank you to Mickey Howell and the biology department staff for making the WVU Biology department a special place. I deeply thank my fellow graduate students for their friendship and support along the way, especially Joe Carrara, Amy Hruska, Jennifer Chandler, and Jessica Turner. Special thanks are necessary for two fellow graduate students in particular. Chris Walter, without your guidance, advise, and friendship, this project would not have been possible. Sandra Simon, your caring patience and support have made these final stages much less stressful. Finally, I thank my family, James, Elizabeth, and David, for their unwavering love and support through my years as an undergraduate and graduate student. Funding for this work came from the Long-Term Research in Environmental Biology (LTREB) program at the National Science Foundation (Grant Nos. DEB-0417678 and DEB-1019522), the National Science Foundation's Research Experience for Undergraduates program (Grant No. DBI-0849917), the Morrissey Ropp Scholarship, the Earl

Core Scholarship, the WVU Foundation Distinguished Doctoral Scholarship, and the WVU Department of Biology and Eberly College of Arts and Sciences. 


\section{Table of Contents}

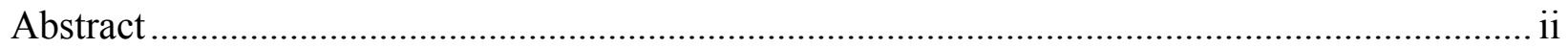

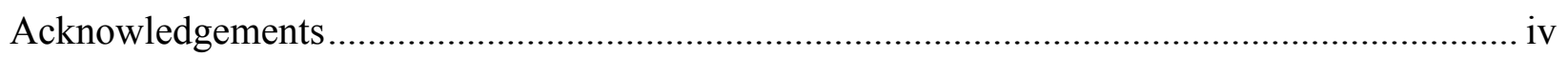

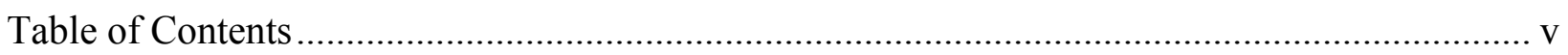

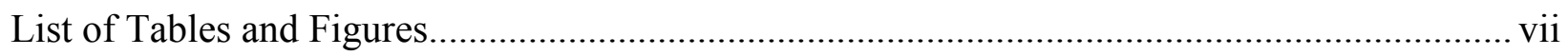

Chapter 1. Introduction: Nitrogen supply and demand dynamics in the Fernow Experimental

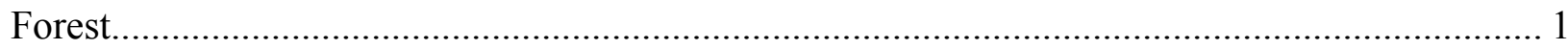

1.1 The N cycle at the Fernow Experimental Forest........................................................ 2

1.2 Tree ring $\delta^{15} \mathrm{~N}$ as an indicator of $\mathrm{N}$ saturation .................................................... 5

1.3 The Fernow Experimental Forest ........................................................................ 7

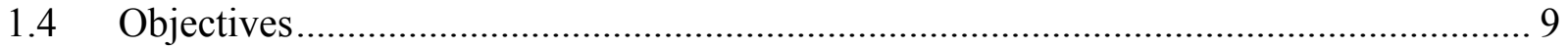

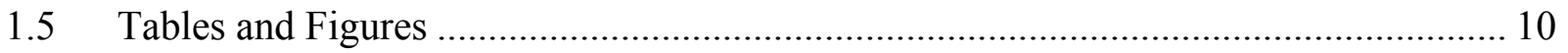

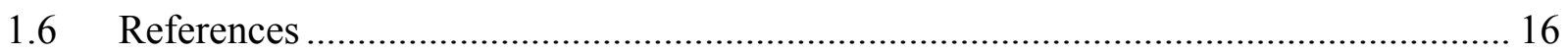

Chapter 2. Does long-term change in species composition affect forest demand for $\mathrm{NO}_{3}$ and stream water $\mathrm{NO}_{3}$ export from a watershed in the central Appalachians? .............................. 22

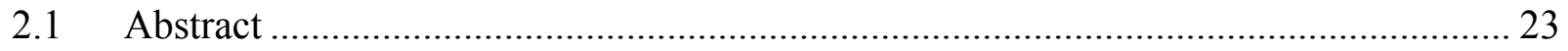

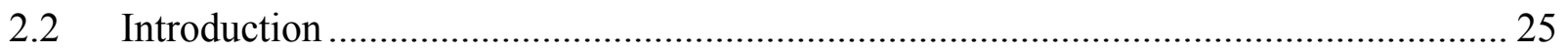

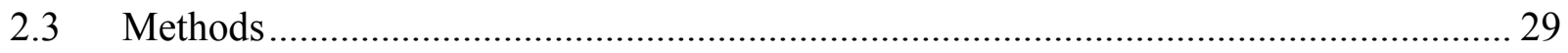

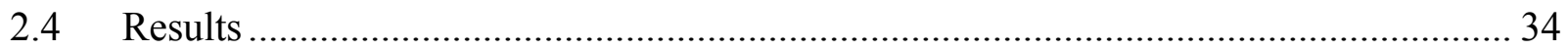

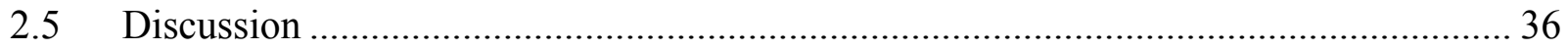

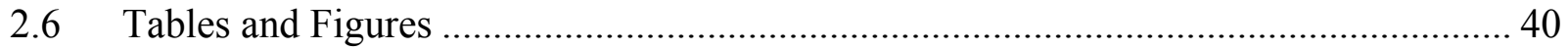

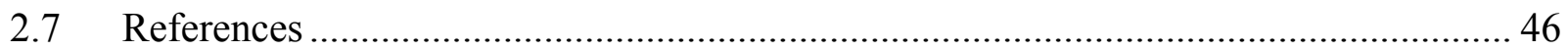

Chapter 3. Soluble soil aluminum alters the relative uptake of mineral nitrogen forms by six mature temperate broadleaf tree species: Possible implications for watershed nitrate retention . 55

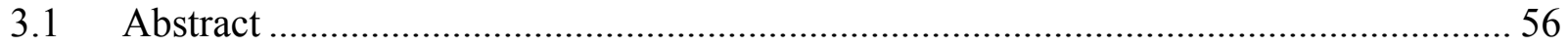

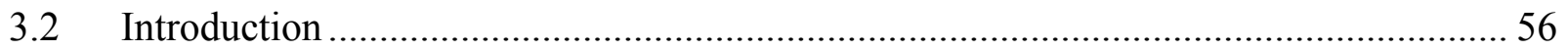

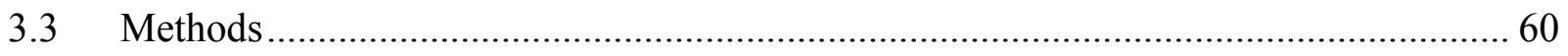

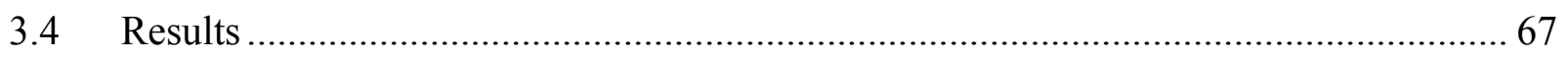

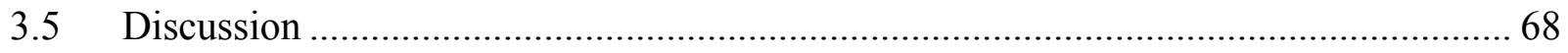

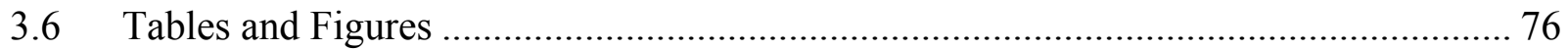

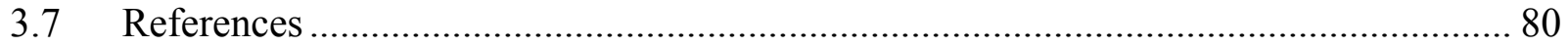


Chapter 4. The response of tree ring $\delta^{15} \mathrm{~N}$ to whole-watershed urea fertilization at the Fernow

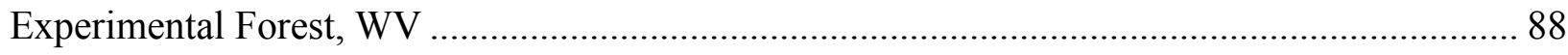

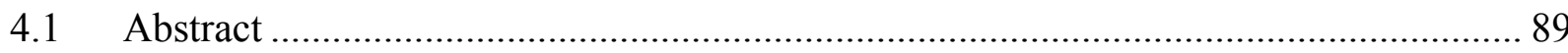

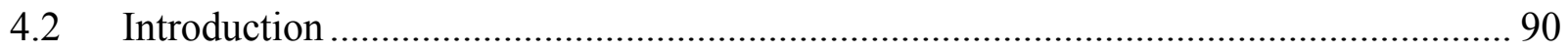

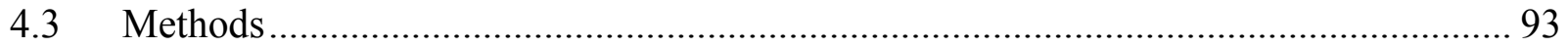

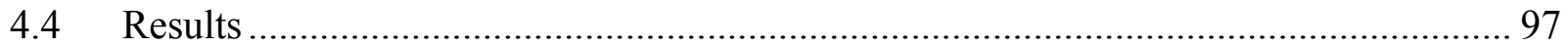

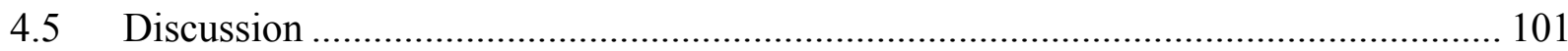

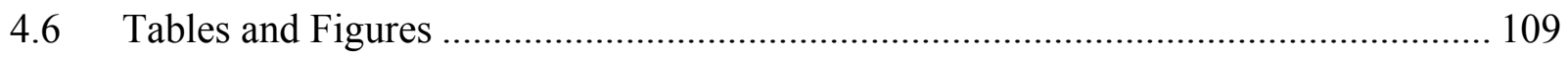

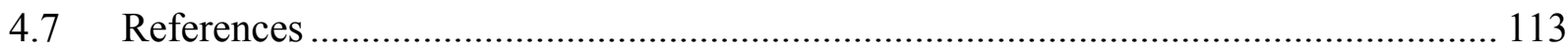

Chapter 5. Assessing tree ring $\delta^{15} \mathrm{~N}$ of different species as an indicator of $\mathrm{N}$ saturation in a temperate forest using independent long-term records of $\mathrm{N}$ cycling and loss ......................... 122

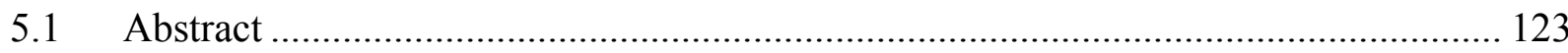

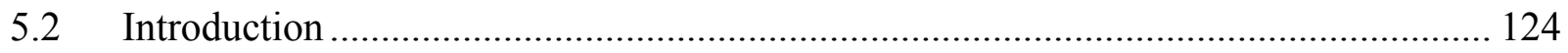

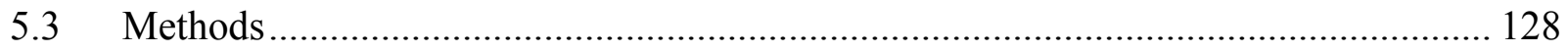

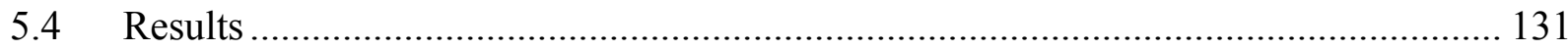

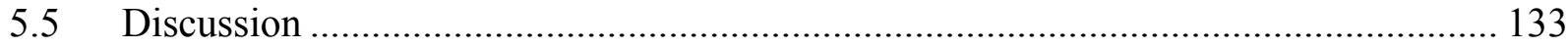

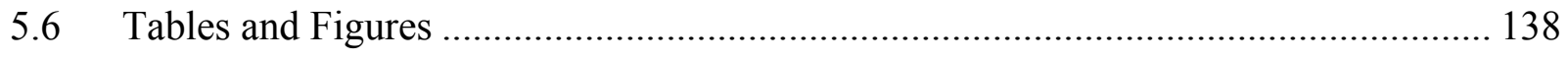

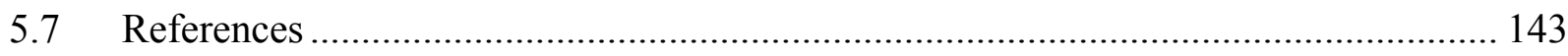

Chapter 6. Conclusion: Moving towards an improved understanding of N supply and demand in

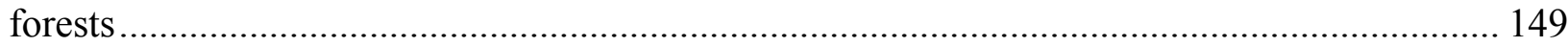

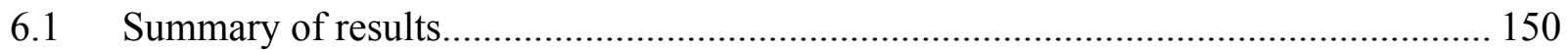

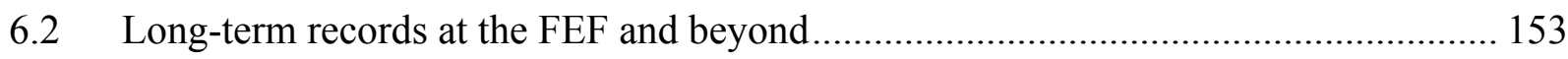

6.3 Towards an improved understanding of watershed $\mathrm{NO}_{3}$ demand and production....... 154

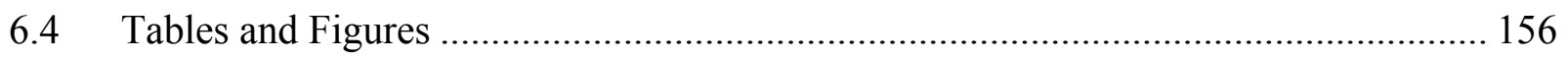

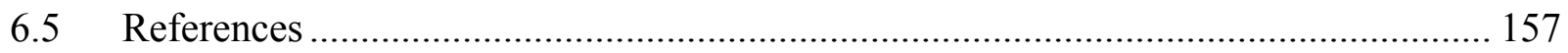

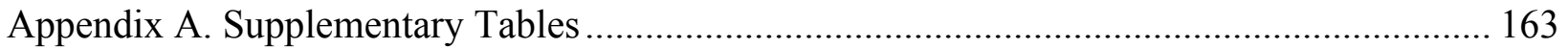




\section{List of Tables and Figures}

Figure 1-1. The watersheds at the FEF used in this study 10

Figure 1-2. Monthly flow-weighted stream water $\mathrm{NO}_{3}$ concentration $(\mu \mathrm{M})$ in FEF WS 4 since 1970, with a 24-month running mean to visualize the temporal trend 11

Figure 1-3. Stream water $\mathrm{NO}_{3}$ discharge $\left(\mathrm{kg} \mathrm{NO}_{3}-\mathrm{N} \mathrm{ha}^{-1} \mathrm{yr}^{-1}\right)$ from FEF WS 3 and 7, 1984-2012

Figure 1-4. The forest $\mathrm{N}$ cycle pools and fluxes, and the aspects investigated using long-term records of $\mathrm{N}$ supply and loss....

Figure 1-5. Acer saccharum relative abundance through time in the FEF (reproduced from Schuler and Gillespie, 2000). 14

Figure 1-6. Monthly flow-weighted stream water $\mathrm{NO}_{3}$ concentration $(\mu \mathrm{M})$ in FEF WS 1 since 1970 , with a 24-month running mean to visualize the temporal trend. The vertical dashed line indicates a one-time urea fertilization $\left(287.1 \mathrm{~kg}\right.$ urea- $\left.\mathrm{N} \mathrm{ha}^{-1}\right)$ in 1971 . Dashed running mean segments include values estimated from the relationship between $\mathrm{NO}_{3}$ and stream water conductivity

Figure 2-1. Flow-weighted monthly average stream water $\mathrm{NO}_{3}$ concentration through time in FEF WS 4. The trend line is a 24-month running mean to visualize the temporal trend ........ 41

Figure 2-2. Annual bulk (wet + dry) $\mathrm{N}$ inputs into and stream discharge from FEF WS 4, and the net $\mathrm{N}$ storage or loss from the catchment.

Figure 2-3. Tree species' relative importance, abundance, and basal area (\%) in FEF WS 4 from 1959 to 2001 . The percent changes for species listed under "other" are changes in RIV. Data from the USDA Forest Service Northern Research Station (Schuler and Wood, 2015) ......... 43

Figure 2-4. The contribution of $\mathrm{NO}_{3}$ to total stand uptake of $\mathrm{N}$ from 1959 to 2001. Different lines represent different estimates of uptake of $\mathrm{N}$ as $\mathrm{NO}_{3}$ for $A$. saccharum, based on prior studies, this study, and the average of all available rates 44

Figure 3-1. Annual stream water $\mathrm{NO}_{3}{ }^{-}$discharge from the acidified (WS3) and reference (WS7) watersheds. Vertical dashed line indicates the start of the annual addition of $35 \mathrm{~kg} \mathrm{~N} \mathrm{ha}^{-1} \mathrm{yr}^{-1}$ as $\left(\mathrm{NH}_{4}\right)_{2} \mathrm{SO}_{4}$ to the acidified watershed. Only years with values for all months were included for a given watershed 76

Figure 3-2. The percent of ${ }^{15} \mathrm{~N}$ taken up from the labeled pools as $\mathrm{NO}_{3}{ }^{-}$in the presence or absence of added $\mathrm{Al}^{3+}$ for the 6 temperate broadleaf tree species, and averaged across all species (far right). Bars that do not share a like letter are significantly different (Tukey's HSD post-hoc analysis, $\alpha=0.05$ ). No individual species percent ${ }^{15} \mathrm{~N}$ uptake as $\mathrm{NO}_{3}{ }^{-}$was significantly affected by $\mathrm{Al}^{3+}$ addition. Dotted line shows $50 \%$ threshold of ${ }^{15} \mathrm{~N}$ uptake as $\mathrm{NO}_{3}{ }^{-}$for visual comparison 
Figure 3-3. Monomeric soil solution $\mathrm{Al}^{3+}(\mu \mathrm{M})$ in three soil fractions of the acidified and reference watersheds. Bars that do not share a like letter are significantly different (Tukey's HSD post-hoc analysis, $\alpha=0.05$ )

Figure 4-1. 24-month running mean of flow weighted monthly stream water $\mathrm{NO}_{3}$ in Fernow Experimental Forest watershed 1 (clear-cut in 1957, fertilized in May, 1971) and watershed 4 (reference, cut circa 1900). Dashed line segments include estimated values based on the relationship between $\mathrm{NO}_{3}$ and stream water conductivity ............................................. 108

Figure 4-2. Mean basal area increment (BAI) of each species through time ( \pm SE)............. 109 Figure 4-3. Mean annual standardized tree ring $\delta^{15} \mathrm{~N}$ by species ( $\mathrm{n}=5$ cores for L. tulipifera and P. serotina, 4 for F. grandifolia and Q. rubra) and 24-month running mean of flow weighted monthly stream water $\mathrm{NO}_{3}$. Dashed vertical lines indicate the 1971 urea fertilization. Dashed line segment in top panel includes estimated values based on the relationship between $\mathrm{NO}_{3}$ and stream water conductivity. Heartwood-sapwood boundaries are indicated by shaded (heartwood) and open (sapwood) horizontal bars in P. serotina and L. tulipifera panels

Figure 4-4. L. tulipifera tree ring $\delta^{15} \mathrm{~N}$ and annual mean of monthly flow-weighted stream water $\mathrm{NO}_{3}$ in a long-term reference watershed (WS 4) at the Fernow Experimental Forest. Trend line is a 2-year moving average of L. tulipifera tree ring $\delta^{15} \mathrm{~N}$ to visually depict the long-term trend. Calculated stream water $\mathrm{NO}_{3}$ values (open circles) are based on the linear relationship between tree ring $\delta^{15} \mathrm{~N}$ and stream water $\mathrm{NO}_{3}$ measurements 1970-2005 $(\mathrm{P}<0.001, \mathrm{r}=0.928)$

Figure 5-1. Locations of the cored trees in watershed 4 (WS 4) at the Fernow Experimental Forest (FEF)

Figure 5-2. Stream water $\mathrm{NO}_{3}$ concentration and tree ring $\delta^{15} \mathrm{~N}$ signature since 1971 . The temporal trend in stream water $\mathrm{NO}_{3}$ is visualized using a 3-year running average of the monthly, flow-weighted stream water $\mathrm{NO}_{3}$ concentration. The average tree ring $\delta^{15} \mathrm{~N}(\mathrm{n}=7$ for each species) is shown for each 3-year time segment, 1971-2000. Note the difference in y-axis scale for L. tulipifera. 139

Figure 5-3. Linear relationship between 2014 soil KCl-extractable $\mathrm{NO}_{3}$ and 2014 tree ring $\delta^{15} \mathrm{~N}$ (all species) $\left(\mathrm{R}^{2}=18.3 \%, \mathrm{P}=0.029\right)$. 140

Figure 5-4. Monthly flow-weighted average stream water $\mathrm{NO}_{3}$ concentration $(\mu \mathrm{M})$ and $Q$. rubra standardized tree ring $\delta^{15} \mathrm{~N}(\%)$ from 1970 through 2000 141

Figure 6-1. The forest $\mathrm{N}$ cycle with the estimated impacts of species composition change and increased $\mathrm{Al}^{3+}$ on $\mathrm{NO}_{3}$ supply and demand at the FEF. 
Table 2-1. The percent of total uptake of mineral $\mathrm{N}_{\text {as }} \mathrm{NO}_{3}$ for six major overstory trees at the

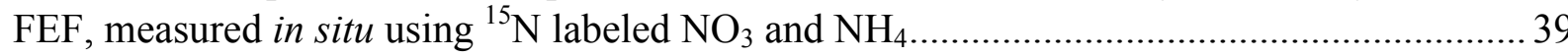

Table 2-2. All available estimates of the percent of total uptake of mineral $\mathrm{N}$ as $\mathrm{NO}_{3}$ and estimated $\mathrm{N}$ uptake rates $\left(\mu \mathrm{mol} \mathrm{NO} \mathrm{NO}_{3}-\mathrm{N}\right.$ g dry $\operatorname{root}^{-1} \mathrm{hr}^{-1}$ ) for $A$. saccharum. Measurement methods and parameters varied by study

Table 3-1. Total soil solution $\mathrm{Al}(\mu \mathrm{M})\left(\right.$ monomeric $\mathrm{Al}^{3+}+$ chelated $\left.\mathrm{Al}\right)$ in three soil fractions within the acidified and reference watersheds, and the percent of total $\mathrm{Al}$ that was chelated. Total Al values that do not share a like letter are significantly different (Tukey's HSD post-hoc

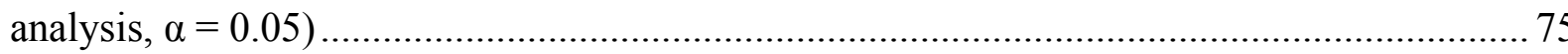

Table 5-1. Mean $\mathrm{KCl}$-extractable soil $\mathrm{N}$ pools and transformation rates $(\mathrm{NMP}=$ net mineralization potential, $\mathrm{NNP}=$ net nitrification potential) under the canopies of each tree species. Means that do not share a letter are significantly different $(\mathrm{P}<0.05) \ldots$

Table A-1.3-way ANOVA results for soil Al analysis by Al form, soil fraction, and watershed. 
Chapter 1. Introduction: Nitrogen supply and demand dynamics in the Fernow Experimental Forest 


\subsection{The $\mathbf{N}$ cycle at the Fernow Experimental Forest}

In temperate forest ecosystems, high nitrogen $(\mathrm{N})$ demand relative to supply often limits forest productivity and plant growth (Vitousek and Howarth 1991; LeBauer and Treseder 2008).

However, throughout the latter half of the $20^{\text {th }}$ century, anthropogenic production of reactive $\mathrm{N}$ compounds increased the input of $\mathrm{N}$ into forests via atmospheric $\mathrm{N}$ deposition (Galloway et al. 2004), often to the point that supply exceeded stand $\mathrm{N}$ demand (Aber et al. 1998). When this saturation of $\mathrm{N}$ occurs, nitrate $\left(\mathrm{NO}_{3}\right)$ loss in stream water (Fenn et al. 2003) can have detrimental effects on waterways (Jaworski et al. 1997; Driscoll et al. 2001) and deplete forest soils of essential base cations. These effects may be especially pronounced in central Appalachia and the northeastern United States, due to high rates of fossil fuel combustion in coal-fired power plants within the Ohio River basin. Thus, forests in this region are particularly well-suited for the study of $\mathrm{N}$ supply and demand through time, and how the internal cycling of $\mathrm{N}$ within forests affects the discharge of $\mathrm{N}$ into waterways.

Long-term records at the Fernow Experimental Forest (FEF) (Figure 1-1) in West Virginia provide us a unique opportunity to observe the effects of $\mathrm{N}$ deposition on stream water chemistry. Watershed 4 (WS 4) at the FEF has one of the longest continuous stream water chemistry records in the region, which reveals a striking 145\% increase in stream water $\mathrm{NO}_{3}$ from 1978 through 1981 (Figure 1-2). This has been attributed to $\mathrm{N}$ saturation resulting from the cumulative deposition of $\mathrm{N}$ through time (Peterjohn et al. 1996). In addition, to better understand the effects of elevated $\mathrm{N}$ deposition and the accompanying acidification of the soil, an adjacent watershed, WS 3, has been treated with $35 \mathrm{~kg} \mathrm{~N} \mathrm{ha}^{-1} \mathrm{yr}^{-1}$ as $\left(\mathrm{NH}_{4}\right)_{2} \mathrm{SO}_{4}$ since 1989 . This added $\mathrm{N}$ input enhanced the imbalance between $\mathrm{N}$ supply and biotic demand, leading to an increase in stream water $\mathrm{NO}_{3}$ output compared to an adjacent, similarly-aged reference watershed (WS 7) (Figure 1-3). Thus, these watersheds provide evidence supporting the idea that increased $\mathrm{N}$ supply causes increased $\mathrm{N}$ discharge, when the $\mathrm{N}$ supply exceeds the $\mathrm{N}$ demand of the forest stand. However, the forest $\mathrm{N}$ demand may not be stationary through time, and so dynamic interactions 
between temporal changes in $\mathrm{N}$ supply and demand can cause variability in patterns of forest watershed retention (Campbell et al. 2004).

The addition of $\mathrm{N}$ to forests does not simply move into stream water if supply exceeds demand, since the forest $\mathrm{N}$ cycle involves multiple organic and mineral $\mathrm{N}$ pools, and a variety of fluxes that are mediated by plants, microbes, and abiotic processes (Figure 1-4) (Aber et al. 1998; Lovett and Goodale 2011). Thus, during base-flow conditions, most $\mathrm{N}$ discharged in stream water has been processed within the ecosystem $\mathrm{N}$ cycle (Rose et al. 2015). This means that changes in the biogeochemical processes, and their rates, within a forested catchment can have a large influence on $\mathrm{N}$ loss, in addition to the amount of $\mathrm{N}$ supplied via deposition. Since numerous factors (both biotic and abiotic) contribute to the high variability in forest watershed $\mathrm{N}$ retention across the northeastern United States, further study of these factors should help clarify what controls stream water $\mathrm{NO}_{3}$ discharge and the manner in which forest ecosystems influence the chemical composition of receiving waters.

One biotic factor that could influence stream $\mathrm{NO}_{3}$ discharge is the composition of tree species found in a watershed, which may not be stationary through time. Indeed, the importance of Acer saccharum in the FEF has dramatically increased over the past century (Schuler and Gillespie 2000). This species may have a unique impact on the watershed $\mathrm{N}$ cycle, because it is typically associated with high $\mathrm{NO}_{3}$ production in the soil (Lovett and Mitchell 2004; Peterjohn et al. 2015). Paradoxically, there are indications that this species may also take up very little $\mathrm{NO}_{3}$, relying predominantly on $\mathrm{NH}_{4}$ to fulfill its demand for $\mathrm{N}$ (Rothstein et al. 1996; BassiriRad et al. 1999; Templer and Dawson 2004; Eddy et al. 2008). Therefore, a long-term shift in species composition in a forested watershed could increase stream water $\mathrm{NO}_{3}$ discharge by both 
increasing $\mathrm{NO}_{3}$ production in the soil (the supply), and by reducing $\mathrm{NO}_{3}$ uptake (the demand) by the forest stand. Supporting this idea is the fact that an increase in the importance of $A$. saccharum in the FEF appears to coincide with the increase in stream water $\mathrm{NO}_{3}$ concentration in WS 4 stream water, and a portion of WS 4 ( $\sim 13.6 \%$ of the watershed) that lacks $A$. saccharum trees has soils that produce and lose very little $\mathrm{NO}_{3}$ (Peterjohn et al. 1999). Thus, in the FEF the increasing importance of $A$. saccharum may have made WS 4 more susceptible to N saturation by enhancing the supply of easily leached $\mathrm{NO}_{3}$, and by reducing the biotic demand for this form of $\mathrm{N}$.

In FEF WS 3, the experimental addition of $\left(\mathrm{NH}_{4}\right)_{2} \mathrm{SO}_{4}$ has clearly increased stream water $\mathrm{NO}_{3}$ discharge (Figure 1-3). The most straightforward explanation for this increase is that the addition of ammonium stimulated the process of microbial nitrification that converts ammonium to nitrate. Surprisingly, however, when we measured net nitrification at 100 locations within WS 3 and WS 7, the adjacent reference watershed, there was no detectable difference in the rates of nitrate production in the mineral soil. So, it seems likely that the rate of $\mathrm{NO}_{3}$ production is not altered by the addition of $\mathrm{NH}_{4}$, and the increase in stream water $\mathrm{NO}_{3}$ concentration may be attributable to some reduction in $\mathrm{NO}_{3}$ demand. Experimental addition of $\left(\mathrm{NH}_{4}\right)_{2} \mathrm{SO}_{4}$ not only increases $\mathrm{N}$ inputs, but also increases soil acidity (Driscoll et al. 2001). While soil acidity can directly impact nitrification (Gundersen and Rasmussen 1990), it also indirectly affects the forest $\mathrm{N}$ cycle through changes in soil chemistry, such as increased $\mathrm{Al}^{3+}$ availability and its toxicity to plants (Delhaize and Ryan 1995). Indeed, increased $\mathrm{Al}^{3+}$ has been shown to impede the uptake of $\mathrm{NO}_{3}$ by plants (Jarvis and Hatch 1986; Durieux et al. 1993; Calba and Jaillard 1997). If the acidification of the soil in WS 3 by experimental addition of $\left(\mathrm{NH}_{4}\right)_{2} \mathrm{SO}_{4}$ increased plant available 
$\mathrm{Al}^{3+}$, which then reduced plant uptake of $\mathrm{NO}_{3}$, it could account for at least some of the increase in stream water $\mathrm{NO}_{3}$ in the absence of higher $\mathrm{NO}_{3}$ production in the soil. Thus, anthropogenic $\mathrm{N}$ and acidic deposition may simultaneously increase $\mathrm{NO}_{3}$ supply and reduce forest $\mathrm{NO}_{3}$ demand, resulting in elevated $\mathrm{NO}_{3}$ discharge into stream water.

\subsection{Tree ring $\delta^{15} \mathrm{~N}$ as an indicator of $\mathrm{N}$ saturation}

Although long-term records at the FEF provide a unique opportunity to study $\mathrm{N}$ cycle dynamics, they are still temporally limited, extending back to, at most, the 1950s. Beyond the FEF, there are very few decadal records of $\mathrm{N}$ cycling at all, even though anthropogenic $\mathrm{N}$ deposition is prevalent across the northeastern US. Fortunately, it may be possible to study environmental change in temperate forests in the absence of direct measurements by using tree rings. Researchers have long used tree ring width to elucidate past climate variability (Douglass 1920), but more recently we have begun to use $\mathrm{N}$ isotopes in tree rings to study temporal changes in $\mathrm{N}$ cycling (Poulson et al. 1995; Gerhart and McLauchlan 2014). Since there is little evidence of strong isotopic fractionation upon $\mathrm{N}$ uptake into plants, the $\delta^{15} \mathrm{~N}$ signature of plant tissue should reflect that of the plant available soil $\mathrm{N}$ pool. As $\mathrm{N}$ availability increases under long-term deposition and the ecosystem becomes $\mathrm{N}$ saturated, a common effect is higher rates of nitrification (Aber et al. 1998), a process that discriminates against the heavier ${ }^{15} \mathrm{~N}$. The resulting $\mathrm{NO}_{3}$ pool is then ${ }^{15} \mathrm{~N}$-depleted, and so more ${ }^{14} \mathrm{~N}$ is lost as the highly mobile $\mathrm{NO}_{3}$ leaches into stream water or is denitrified. This enriches the remaining $\mathrm{N}$ pool in ${ }^{15} \mathrm{~N}$, which is then stored in annual tree rings. So it appears that the $\delta^{15} \mathrm{~N}$ signature of tree rings has the potential to integrate the local $\mathrm{N}$ cycle (Robinson 2001) and signal the occurrence of $\mathrm{N}$ saturation resulting from a long-term increase in $\mathrm{N}$ deposition. 
Despite its growing use to study temporal or spatial changes in the $\mathrm{N}$ cycle, the utility of plant tissue $\delta^{15} \mathrm{~N}$ as an indicator of $\mathrm{N}$ availability and $\mathrm{N}$ saturation remains in question. The numerous biotic and abiotic processes and pools of the forest $\mathrm{N}$ cycle make it difficult to determine what affects plant $\delta^{15} \mathrm{~N}$ and how $\mathrm{N}$ cycle changes would impact plant tissue isotopes. There is also high variability in tree ring $\delta^{15} \mathrm{~N}$ trajectories, and so increasing and decreasing trends in tree ring $\delta^{15} \mathrm{~N}$ have both been attributed to increased $\mathrm{N}$ deposition (Poulson et al. 1995; Hogberg 1997; Choi et al. 2005; Bukata and Kyser 2007; Savard et al. 2009; Sun et al. 2010; McLauchlan et al. 2017). In addition, other factors can impact plant $\delta^{15} \mathrm{~N}$, such as the species examined (McLauchlan and Craine 2012), stand dynamics (Falxa-Raymond et al. 2012), and climate (Chen et al. 2017). Thus, it is difficult to unequivocally interpret temporal trends in tree ring $\delta^{15} \mathrm{~N}$ without verification of its accuracy as an indicator of $\mathrm{N}$ availability.

The long-term measurements of stream water $\mathrm{N}$ concentrations at two locations in the FEF allow us to independently assess the usefulness of tree ring $\delta^{15} \mathrm{~N}$ as an indicator of $\mathrm{N}$ saturation. In 1971, a one-time experimental addition of urea to FEF WS 1 caused a short-lived increase in stream water $\mathrm{NO}_{3}$ (Figure 1-6), followed by a second, smaller increase that coincided with the $\mathrm{N}$ saturation signal found in a nearby reference watershed (WS 4). Both events are instances of N supply exceeding demand, which should enhance $\mathrm{NO}_{3}$ loss, the $\delta^{15} \mathrm{~N}$ of the soil $\mathrm{N}$ pool, and the $\delta^{15} \mathrm{~N}$ of plant tissue. The second location of interest in the FEF is a well-studied, relatively undisturbed, reference watershed (WS 4), where a significant increase in stream water $\mathrm{NO}_{3}$ occurred around 1980. As such, the FEF is an excellent setting to study the impact of $\mathrm{N}$ supply 
and demand dynamics on tree ring $\delta^{15} \mathrm{~N}$ in order to rigorously assess its ability to record changes in the $\mathrm{N}$ cycle through time.

\subsection{The Fernow Experimental Forest ${ }^{1}$}

The FEF is a USDA research forest and NSF LTREB site in Tucker County, WV. It is a mixedhardwood forest with predominantly Calvin channery silt loam soil (mesic Typic Dystrochrept). Elevation ranges from 762 to $854 \mathrm{~m}$. Timber in the region was heavily harvested ca. 1900, and the 1,902-ha area that is now the FEF was allowed to regenerate after logging activities until experimental treatments commenced in the 1950s (Reinhart et al. 1963; Trimble 1977). During the 1930s, chestnut blight decimated the American chestnut population, which had comprised about $25 \%$ of the timber volume at the FEF.

Watershed 4 (WS 4) at the FEF serves as a reference area for comparison to various silvicultural and other experimental treatments. It has been left to regenerate naturally since the logging activities in the early $20^{\text {th }}$ century, except for removal of blight-affected American chestnut trees in the 1930s. Continuous stream flow is monitored at a V-notch weir using water level recorders. Weekly grab samples for stream water $\mathrm{pH}$ and conductivity have been collected since 1958, and analyzed for a variety of nutrients, including $\mathrm{NO}_{3}$, since 1970 . The WS 4 volume-weighted mean monthly $\mathrm{NO}_{3}$ concentration record is one of the longest continuous stream water nutrient records in the U.S., and it reveals that the stream water $\mathrm{NO}_{3}$ concentration increased $\sim 145 \%$ during the late 1970s and early 1980s, after which it stabilized at $\sim 55 \mu \mathrm{M}$ (Figure 1-2).

\footnotetext{
${ }^{1}$ Site description is adapted from (Kochenderfer 2006).
} 
Whole-watershed fertilization treatments have occurred in two areas of the FEF. The first area includes two small, and adjacent watersheds (WS 3 \& WS 7) that act as a paired-watershed fertilization study, with fertilizer being applied to WS 3 and with WS 7 acting as a reference. Both watersheds were last harvested ca. 1970 and allowed to regenerate naturally until 1989 when WS 3 began to be fertilized with $35 \mathrm{~kg} \mathrm{~N} \mathrm{ha}^{-1} \mathrm{yr}^{-1}$ as $\mathrm{NH}_{4} \mathrm{SO}_{4}$ - a treatment that has continued to the present day. The second fertilized area I examined in the FEF is Watershed 1 (WS 1) which has the same measurement history as WS 4, but was destructively clear-cut in the 1950s as an experimental silvicultural treatment. Since that time, the watershed has been regenerating naturally, with the exception of a one-time, $287.1 \mathrm{~kg} \mathrm{~N} \mathrm{ha}^{-1}$ application of urea in 1971, which significantly elevated stream water nitrate (Figure 1-6). 


\subsection{Objectives}

Building on the long-term observations made at the FEF, I address four primary objectives in this dissertation (Figure 1-4):

Objective 1 (Chapter 2): Evaluate if a shift in species composition in WS 4 (especially an increase in the importance of sugar maple) has reduced the overall uptake of $\mathrm{NO}_{3}$ by the forest, thereby contributing to greater $\mathrm{NO}_{3}$ export in stream water. This objective will be accomplished by using estimates of total $\mathrm{N}$ uptake and temporal changes in stand composition, as well as in situ measurements of the form of mineral $\mathrm{N}\left(\mathrm{NO}_{3} \mathrm{vs}\right.$. $\left.\mathrm{NH}_{4}\right)$ taken up by the roots of six temperate broadleaf tree species that are common in WS 4.

Objective 2 (Chapter 3): Determine if the experimental addition of ammonium sulfate to WS 3 has exposed tree roots to higher levels of free, unchelated $\mathrm{Al}^{3+}$, evaluate if this exposure could change the relative uptake of different forms of mineral $\mathrm{N}$ by important tree species $i n$ situ, and provide an initial assessment of the potential impact that any $\mathrm{Al}^{3+}$-induced reduction in $\mathrm{NO}_{3}$ uptake might have on stream water $\mathrm{NO}_{3}$ export from WS 3.

Objective 3 (Chapter 4): Examine how effectively the tree ring $\delta^{15} \mathrm{~N}$ of four temperate broadleaf deciduous tree species records an experimentally induced change in the N cycle of WS 1 that was caused by a large, one-time addition of urea.

Objective 4 (Chapter 5): Assess the ability of tree ring $\delta^{15} \mathrm{~N}$ of the same temperate tree species examined in WS 1 to respond to increased soil $\mathrm{NO}_{3}$ supply and record $\mathrm{N}$ saturation using soil nitrification measurements and long-term stream water $\mathrm{NO}_{3}$ records in WS 4 . 


\subsection{Tables and Figures}

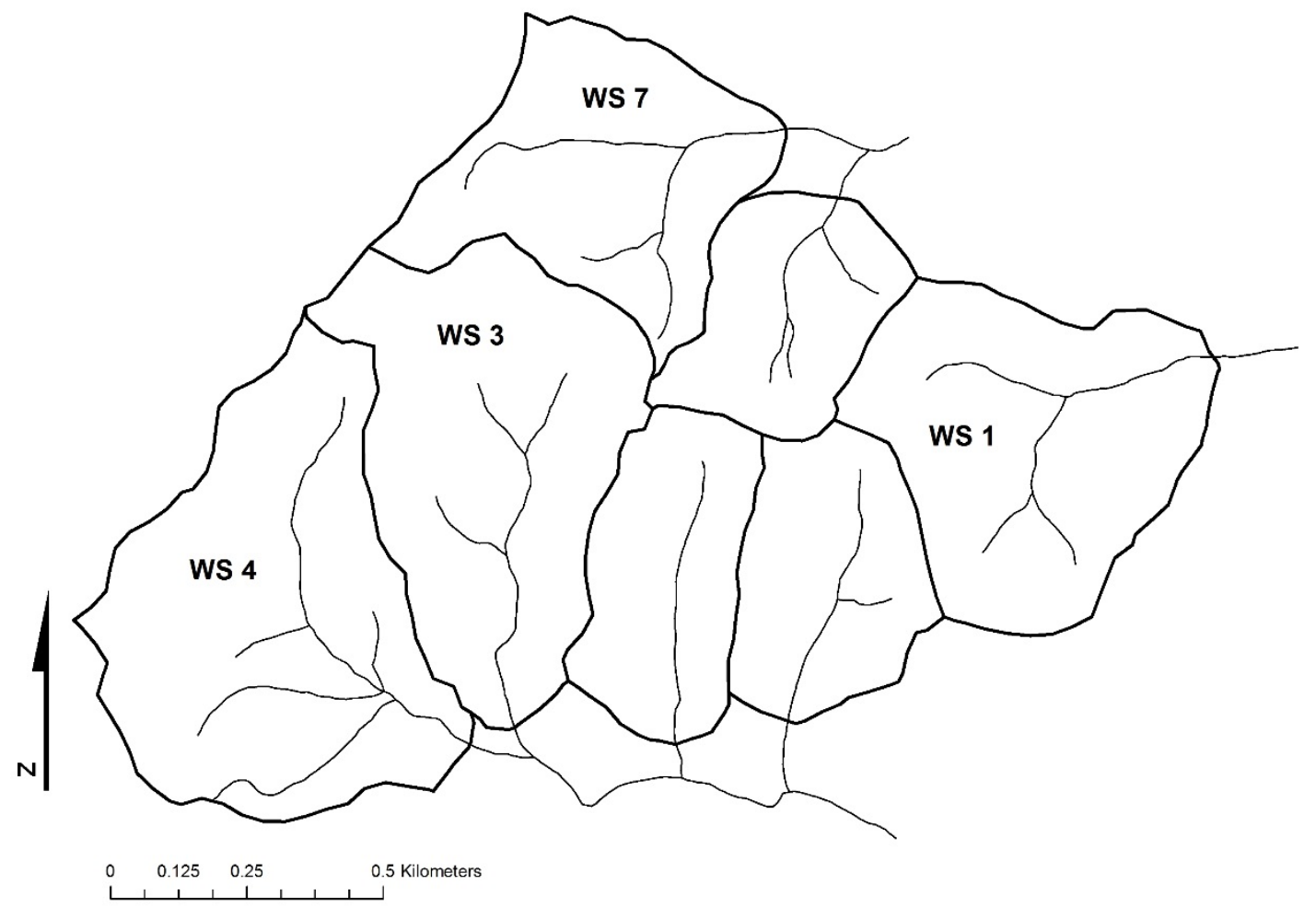

Figure 1-1. The watersheds at the FEF used in this study. 


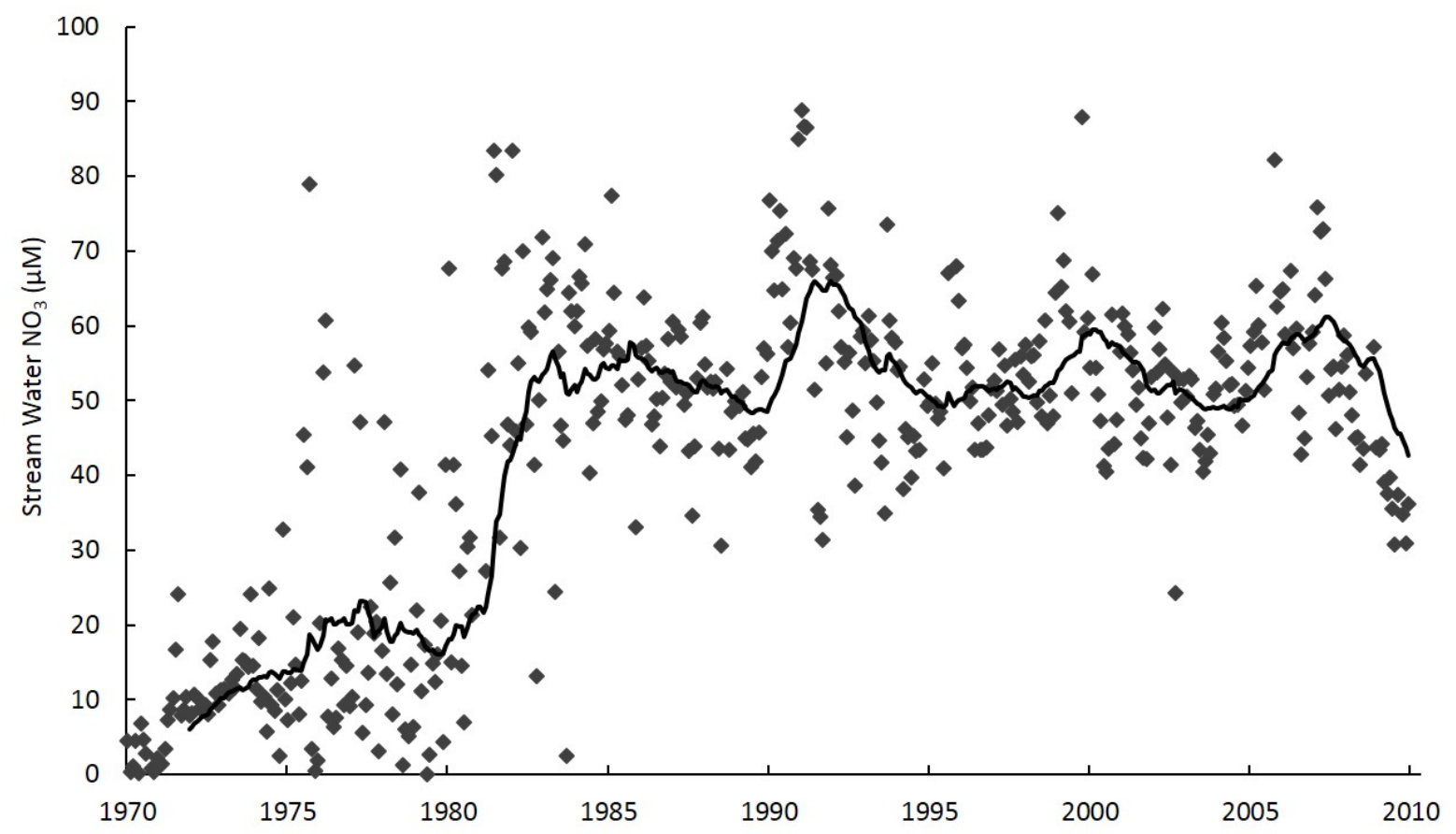

Figure 1-2. Monthly flow-weighted stream water $\mathrm{NO}_{3}$ concentration $(\mu \mathrm{M})$ in FEF WS 4 since 1970, with a 24-month running mean to visualize the temporal trend. 


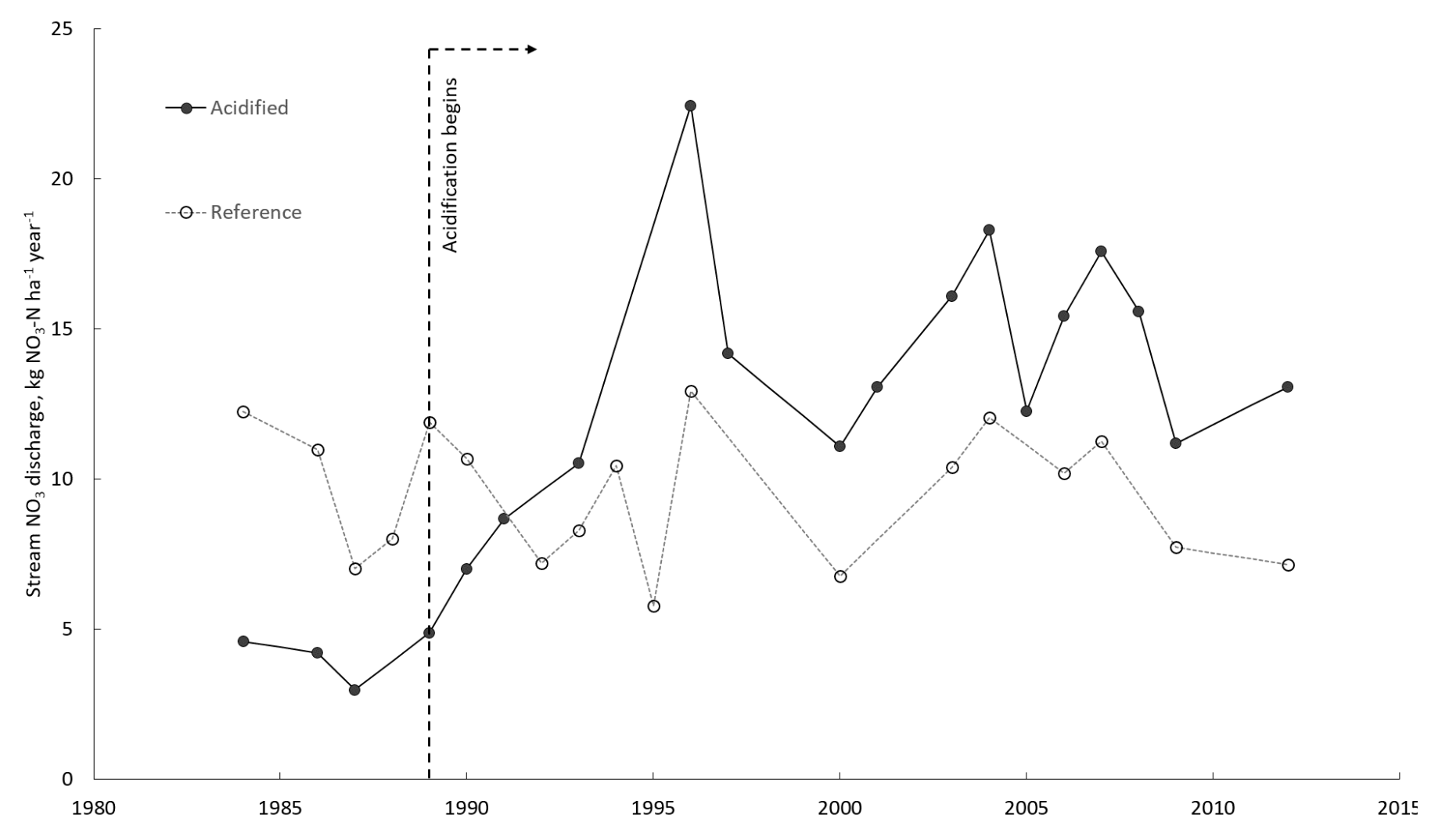

Figure 1-3. Stream water $\mathrm{NO}_{3}$ discharge $\left(\mathrm{kg} \mathrm{NO}_{3}-\mathrm{N} \mathrm{ha}^{-1} \mathrm{yr}^{-1}\right)$ from FEF WS 3 (acidified) and 7 (reference), 1984-2012. 


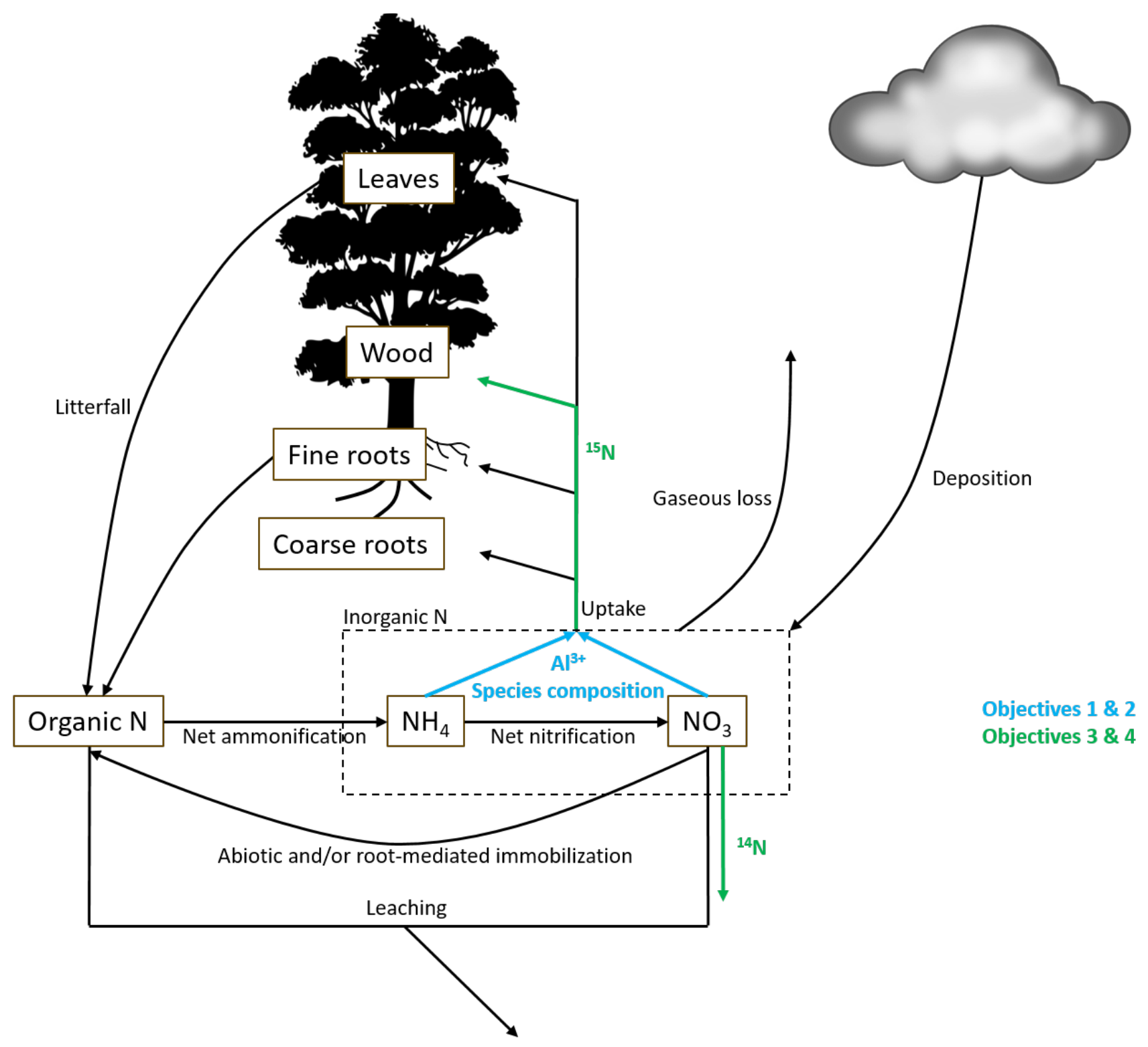

Figure 1-4. The forest $\mathrm{N}$ cycle pools and fluxes, and the aspects investigated using long-term records of $\mathrm{N}$ supply and loss. 


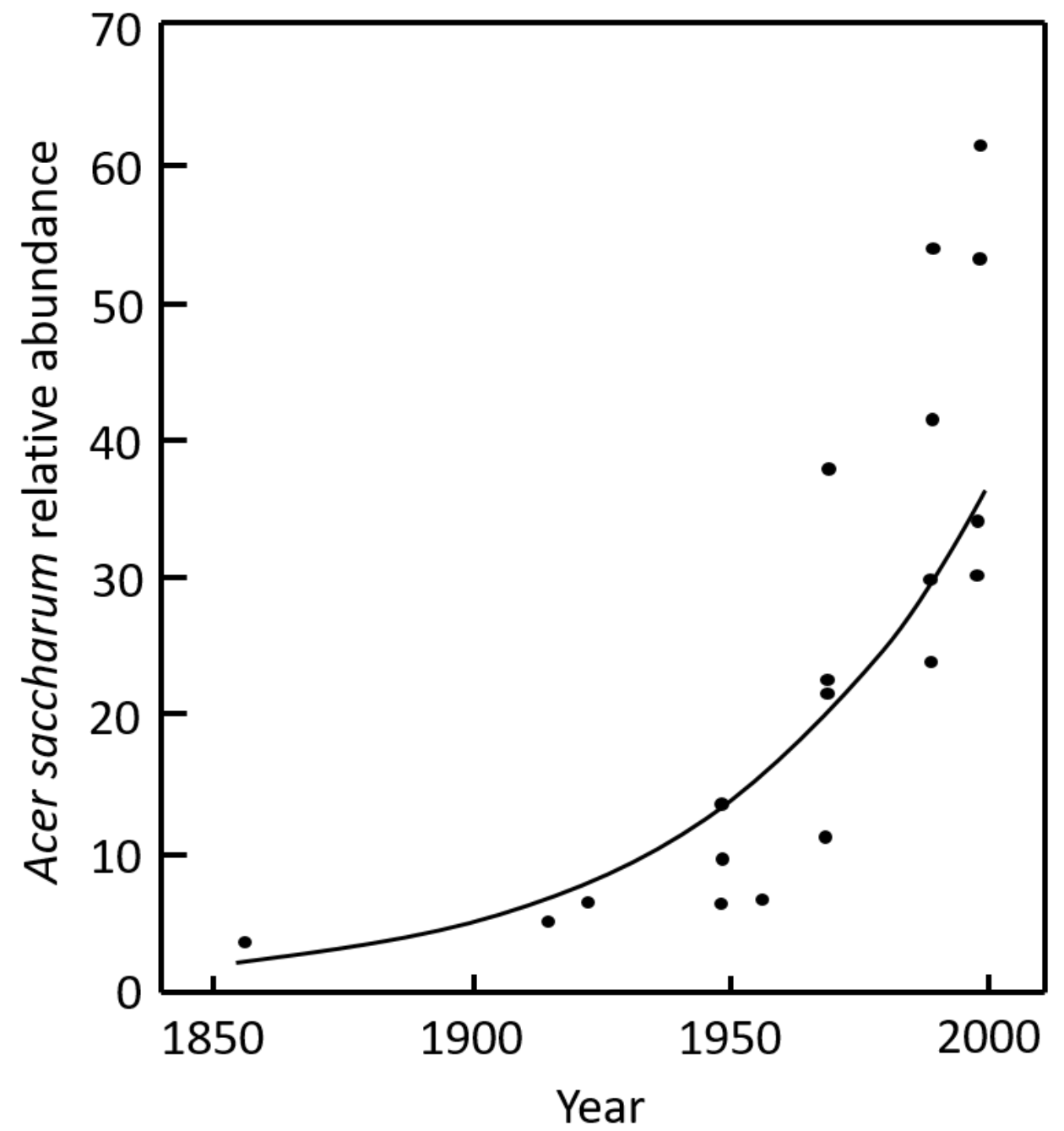

Figure 1-5. Acer saccharum relative abundance (A. saccharum stems divided by total stems, expressed as percent) through time in the FEF (reproduced from Schuler and Gillespie, 2000). 


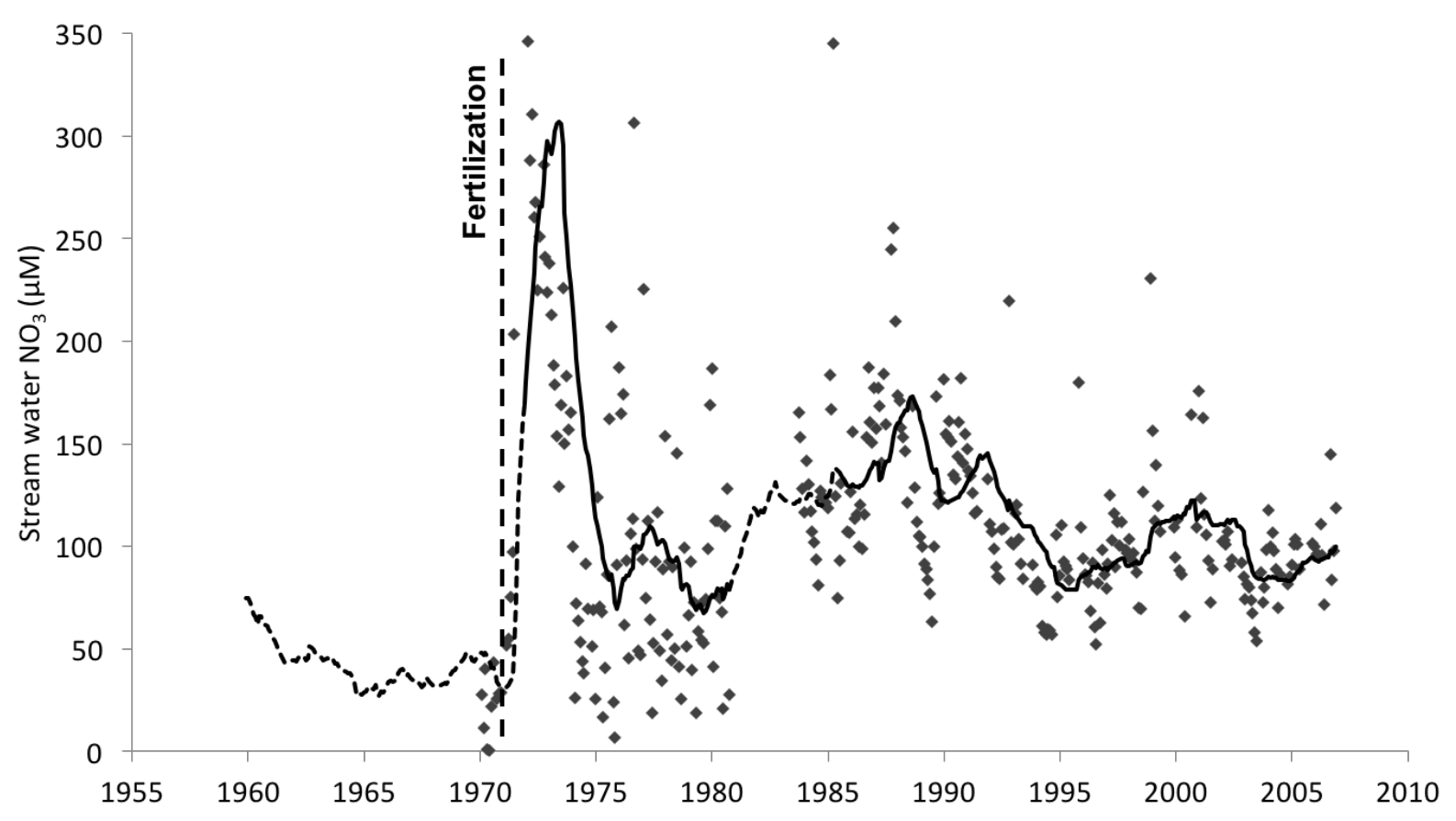

Figure 1-6. Monthly flow-weighted stream water $\mathrm{NO}_{3}$ concentration $(\mu \mathrm{M})$ in FEF WS 1 since 1970, with a 24-month running mean to visualize the temporal trend. The vertical dashed line indicates a one-time urea fertilization $\left(287.1 \mathrm{~kg}\right.$ urea-N ha $\left.{ }^{-1}\right)$ in 1971. Dashed running mean segments include values estimated from the relationship between $\mathrm{NO}_{3}$ and stream water conductivity. 


\subsection{References}

Aber J, McDowell W, Nadelhoffer K, Magill A, Bernston G, Kamakea M, McNulty S, Currie W, Rustad L, Fernandez I (1998) Nitrogen saturation in temperate forest ecosystems. Bioscience 48:921-934.

Aber JD, Nadelhoffer KJ, Steudler P, Melillo JM (1989) Nitrogen saturation in northern forest ecosystems. Bioscience 39:378-386.

BassiriRad H, Prior S, Norby R, Rogers $\mathrm{H}$ (1999) A field method of determining $\mathrm{NH}_{4}{ }^{+}$and $\mathrm{NO}_{3}{ }^{-}$ uptake kinetics in intact roots: Effects of $\mathrm{CO}_{2}$ enrichment on trees and crop species. Plant Soil 217:195-204.

Bukata AR, Kyser TK (2007) Carbon and nitrogen isotope variations in tree-rings as records of perturbations in regional carbon and nitrogen cycles. Environ Sci Technol 41:1331-1338.

Calba H, Jaillard B (1997) Effect of aluminum on ion uptake and $\mathrm{H}^{+}$release by maize. New Phytol 137:607-616.

Campbell JL, Hornbeck JW, Mitchell MJ, Adams MB, Castro MS, Driscoll CT, Kahl JS, Kochenderfer JN, Likens GE, Lynch JA, Murdoch PS, Nelson SJ, Shanley JB (2004) Inputoutput budgets of inorganic nitrogen for 24 forest watersheds in the northeastern United States: A review. Water Air Soil Pollut 151:373-396.

Chen C, Li J, Wang G, Shi M (2017) Accounting for the effect of temperature in clarifying the response of foliar nitrogen isotope ratios to atmospheric nitrogen deposition. Sci Total Environ 609:1295-1302. doi: 10.1016/j.scitotenv.2017.06.088

Choi W-J, Lee S-M, Chang SX, Ro H-M (2005) Variations of $\delta^{13} \mathrm{C}$ and $\delta^{15} \mathrm{~N}$ in Pinus densiflora tree-rings and their relationship to environment changes in eastern Korea. Water Air Soil Pollut 164:173-187. 
Christ M, Peterjohn W, Cumming J, Adams M (2002) Nitrification potentials and landscape, soil and vegetation characteristics in two Central Appalachian watersheds differing in NO3export. For Ecol Manage 159:145-158.

Delhaize E, Ryan P (1995) Aluminum toxicity and tolerance in plants. Plant Physiol 107:315321.

Douglass AE (1920) Evidence of climatic effects in the annual rings of trees. Ecology 1:24-32.

Driscoll CT, Lawrence GB, Bulger AJ, Butler TJ, Cronan CS, Eagar C, Lambert KF, Likens GE, Stoddard JL, Weathers KC (2001) Acidic deposition in the northeastern United States: Sources and inputs, ecosystems effects, and management strategies. Bioscience 51:180198. doi: 10.1641/0006-3568(2001)051[0180:ADITNU]2.0.CO;2

Durieux R, Jackson W, Kamprath E, Moll R (1993) Inhibition of nitrate uptake by aluminum in maize. Plant Soil 151:97-104.

Eddy WC, Zak DR, Holmes WE, Pregitzer KS (2008) Chronic Atmospheric $\mathrm{NO}_{3}{ }^{-}$Deposition Does Not Induce $\mathrm{NO}_{3}{ }^{-}$Use by Acer saccharum Marsh. Ecosystems 11:469-477. doi: $10.1007 / \mathrm{s} 10021-008-9134-3$

Falxa-Raymond N, Patterson AE, Schuster WSF, Griffin KL (2012) Oak loss increases foliar nitrogen, $\delta^{15} \mathrm{~N}$ and growth rates of Betula lenta in a northern temperate deciduous forest. Tree Physiol 32:1092-1101. doi: 10.1093/treephys/tps068

Fenn M, Baron J, Allen E, Rueth H, Nydick K, Geiser L, Bowman W, Sickman J, Meixner T, Johnson D, Neitlich P (2003) Ecological effects of nitrogen deposition in the western United States. Bioscience 53:404-420. doi: 10.1641/0006-3568(2003)053 
Galloway J, Dentener F, Capone D, Boyer E, Howarth R, Seitzinger S, Asner G, Cleveland C, Green P, Holland E, Karl D, Michaels A, Porter J, Townsend A, Vorosmarty C (2004) Nitrogen cycles: past, present, and future. Biogeochemistry 70:153-226.

Gerhart LM, McLauchlan KK (2014) Reconstructing terrestrial nutrient cycling using stable nitrogen isotopes in wood. Biogeochemistry 120:1-21. doi: 10.1007/s10533-014-9988-8

Gundersen P, Rasmussen L (1990) Nitrification in forest soils: Effects from nitrogen deposition on soil acidification and aluminum release. Rev Environ Contam Toxicol 113:1-45. doi: $10.1177 / 0192513 X 12437708$

Hogberg P (1997) 15N natural abundance in soil-plant systems. New Phytol 137:179-203.

Jarvis SC, Hatch DJ (1986) The effects of low concentrations of aluminum on the growth and uptake of nitrate-N by white clover. Plant Soil 95:43-55.

Jaworski NA, Howarth RW, Hetling LJ (1997) Atmospheric Deposition of Nitrogen Oxides onto the Landscape Contributes to Coastal Eutrophication in the Northeast United States. Environ Sci Technol 31:1995-2004. doi: 10.1021/es960803f

Kochenderfer JN (2006) Fernow and the Appalachian Hardwood Region. In: Adams M, DeWalle D, Hom J (eds) The Fernow Watershed Acidification Study. Springer, Dordrecht, pp 17-39

LeBauer DS, Treseder KK (2008) Nitrogen Limitation of Net Primary Productivity in Terrestrial Ecosystems Is Globally Distributed. Ecology 89:371-379.

Lovett G, Mitchell M (2004) Sugar maple and nitrogen cycling in the forests of Eastern North America. Front Ecol Environ 2:81-88. 
Lovett GM, Goodale CL (2011) A new conceptual model of nitrogen saturation based on experimental nitrogen addition to an oak forest. Ecosystems 14:615-631. doi: 10.1007/s10021-011-9432-z

Lovett GM, Weathers KC, Arthur MA, Schultz JC (2004) Nitrogen cycling in a northern hardwood forest: Do species matter? Biogeochemistry 67:289-308. doi: 10.1023/B:BIOG.0000015786.65466.f5

McLauchlan KK, Craine JM (2012) Species-specific trajectories of nitrogen isotopes in Indiana hardwood forests, USA. Biogeosciences 9:867-874. doi: 10.5194/bgd-8-5935-2011

McLauchlan KK, Gerhart LM, Battles JJ, Craine JM, Elmore AJ, Higuera PE, Mack MC, McNeil BE, Nelson DM, Pederson N, Perakis SS (2017) Centennial-scale reductions in nitrogen availability in temperate forests of the United States. Sci Rep 7:7856. doi: $10.1038 / \mathrm{s} 41598-017-08170-\mathrm{z}$

Peterjohn WT, Adams MB, Gilliam FS (1996) Symptoms of nitrogen saturation in two central Appalachian hardwood forest ecosystems. Biogeochemistry 35:507-522.

Peterjohn WT, Foster CJ, Christ MJ, Adams MB (1999) Patterns of nitrogen availability within a forested watershed exhibiting symptoms of nitrogen saturation. For Ecol Manage 119:247257. doi: $10.1016 / \mathrm{S} 0378-1127(98) 00526-\mathrm{X}$

Peterjohn WT, Harlacher MA, Christ MJ, Adams MB (2015) Testing associations between tree species and nitrate availability: Do consistent patterns exist across spatial scales? For Ecol Manage 358:335-343. doi: 10.1016/j.foreco.2015.09.018

Poulson S, Chamberlain C, Friedland A (1995) Nitrogen isotope variation of tree rings as a potential indicator of environmental change. Chem Geol 125:307-315. 
Reinhart K, Eschner A, Trimble G (1963) Effect on streamflow of four forest practices in the mountains of West Virginia.

Robinson D (2001) $\delta 15 \mathrm{~N}$ as an integrator of the nitrogen cycle. Trends Ecol Evol 16:153-162.

Rose L, Sebestyen S, Elliott E, Koba K (2015) Drivers of atmospheric nitrate processing and export in forested catchments. Water Resour Res 51:1333-1352. doi:

10.1002/2014WR015716

Rothstein DE, Zak DR, Pregitzer KS, Url S, Zak R (1996) Nitrate deposition in northern hardwood forests and the nitrogen metabolism of Acer saccharum Marsh. Oecologia 108:338-344.

Savard MM, Bégin C, Smirnoff A, Marion J, Rioux-Paquette E (2009) Tree-ring nitrogen isotopes reflect anthropogenic NOx emissions and climatic effects. Environ Sci Technol 43:604-9.

Schuler T, Gillespie A (2000) Temporal patterns of woody species diversity in a central Appalachian forest from 1856 to 1997 . J Torrey Bot Soc 127:149-161.

Sun F, Kuang Y, Wen D, Xu Z, Li J, Zuo W, Hou E (2010) Long-term tree growth rate, water use efficiency, and tree ring nitrogen isotope composition of Pinus massoniana L. in response to global climate change and local nitrogen deposition in Southern China. J Soils Sediments 10:1453-1465. doi: 10.1007/s11368-010-0249-8

Templer PH, Dawson TE (2004) Nitrogen uptake by four tree species of the Catskill Mountains, New York: implications for forest N dynamics. Plant Soil 262:251-261. doi:

10.1023/B:PLSO.0000037047.16616.98 
Trimble G (1977) A history of the Fernow Experimental Forest and the Parsons Timber and Watershed Laboratory. USDA Forest Service General Technical Report NE-28, Northeastern Forest Experiment Station, Upper Darby, PA.

Vitousek P, Howarth R (1991) Nitrogen limitation on land and in the sea: how can it occur? Biogeochemistry 13:87-115. 
Chapter 2. Does long-term change in species composition affect forest demand for $\mathrm{NO}_{3}$ and stream water $\mathrm{NO}_{3}$ export from a watershed in the central Appalachians?

Formatted for the journal Forest Ecology and Management 


\subsection{Abstract}

As depositional inputs of $\mathrm{N}$ change through time, many factors govern the flow of deposited $\mathrm{N}$ through forest ecosystems and into stream water. At the Fernow Experimental Forest in WV, a long-term reference watershed (WS 4) experienced an increase in stream water nitrate $\left(\mathrm{NO}_{3}\right)$ discharge around 1980, presumably due to chronic $\mathrm{N}$ deposition. Around the same time, the species composition of the forest was also changing in ways that could alter forest $\mathrm{N}$ demand and the retention of deposited $\mathrm{N}$. In particular, there was an increase in WS 4 of the importance of Acer saccharum - a species thought to have a low affinity for $\mathrm{NO}_{3}$. Thus, we measured the relative uptake of $\mathrm{NO}_{3}$ and $\mathrm{NH}_{4}$ by six important temperate broadleaf tree species, including $A$. saccharum, and estimated stand uptake of total $\mathrm{N}, \mathrm{NO}_{3}$, and $\mathrm{NH}_{4}$. We then used long-term records of stream water $\mathrm{NO}_{3}$ and stand composition to evaluate the potential impact of a change in species composition on $\mathrm{NO}_{3}$ discharge. The importance values of $A$. saccharum and $A$. rubrum increased more than any other species (5.8 and 8.5\%, respectively). Surprisingly, the six tree species we examined all utilized both mineral $\mathrm{N}$ forms approximately equally, and did not differ in their relative uptake of $\mathrm{NO}_{3}$ and $\mathrm{NH}_{4}$. Overall, the total $\mathrm{N}$ taken up by the stand into aboveground tissues (wood and leaves) increased from 40.9 to $47.4 \mathrm{~kg}$ $\mathrm{N} \mathrm{ha}^{-1} \mathrm{yr}^{1}$ from 1959 through 2001. Therefore, a reduction in the stand $\mathrm{N}$ demand did not contribute to the $145 \%$ increase in stream water $\mathrm{NO}_{3}$ concentration from 1978 through 1981. However, the changes in species composition likely increased the net supply of $\mathrm{NO}_{3}$ in the soil, since $A$. saccharum is typically associated with high soil nitrification rates. This effect potentially increased the supply of soil $\mathrm{NO}_{3}$ by $3.9 \mathrm{~kg} \mathrm{~N} \mathrm{ha}^{-1} \mathrm{yr}^{-1}$ from 
1959 through 2001, contributing to elevated stream water $\mathrm{NO}_{3}$ concentrations and low $\mathrm{N}$ retention in WS 4. 


\subsection{Introduction}

The northeastern United States experienced relatively high atmospheric $\mathrm{N}$ deposition over the latter half of the $20^{\text {th }}$ century (Driscoll et al., 2001; Galloway et al., 2004), increasing $\mathrm{N}$ supply into some forested ecosystems enough that the availability of $\mathrm{N}$ exceeded stand $\mathrm{N}$ demand - a situation that can cause significant nitrate $\left(\mathrm{NO}_{3}\right)$ leaching (Aber et al., 1998). Substantial loss of $\mathrm{NO}_{3}$ contributes to an associated leaching of base cations, such as calcium and magnesium, that are important to plant growth (Adams et al., 1997; Boggs et al., 2005; Edwards et al., 2006), and may have negative effects downstream (Driscoll et al., 2001). Since the passage and subsequent amendment of the Clean Air Act, national emissions of $\mathrm{NO}_{\mathrm{x}}$ and deposition of $\mathrm{N}$ have steadily declined; however, the response of forested catchments is variable. Some have lower $\mathrm{N}$ discharge following national emission and deposition trends, while the levels of $\mathrm{N}$ discharge in others remain high and result in declining inorganic $\mathrm{N}$ retention (Argerich et al., 2013; Likens and Buso, 2012; Skjelkvåle et al., 2005). Given the ecological implications of N discharge into stream water, it is important to understand what controls watershed responses to changes in $\mathrm{N}$ deposition through time.

Many factors (both belowground and aboveground) can impact the retention and discharge of $\mathrm{N}$ deposited into forests (Fenn et al., 1998). Below ground, soil organic matter is the largest pool of $\mathrm{N}$ in temperate forests and is a major sink for added $\mathrm{N}$ (Nadelhoffer et al., 1999). Microbial immobilization, mineralization, and nitrification control mineral $\mathrm{N}$ availability in the soil (Goodale et al., 2015), and net nitrification has a large impact on $\mathrm{N}$ discharge due to the mobility of $\mathrm{NO}_{3}$ in soils. Above ground, stand age 
has a large impact on $\mathrm{N}$ retention, as young, aggrading stands retain more $\mathrm{N}$ due to greater $\mathrm{N}$ demand (Fenn et al., 1998). Even between stands of similar age, differences in species composition lead to differences in $\mathrm{N}$ retention and loss (Aber et al., 1998; Christ et al., 2002; Lovett et al., 2004; Peterjohn et al., 2015). As a result, gradual changes in species composition through time could also impact watershed $\mathrm{N}$ retention, but are more challenging to study due to the need for long-term records.

Fortunately, there are long-term records of changes in both stream-water nitrate (since 1970) and the composition of tree species (since 1959) in a reference watershed (WS 4) at the Fernow Experimental Forest (FEF) in the central Appalachian Mountains of West Virginia. From 1975 to 1984 , there was a $435 \%$ increase ( 1.3 to $\left.6.9 \mathrm{~kg} \mathrm{~N} \mathrm{ha}^{-1} \mathrm{yr}^{-1}\right)$ in stream water $\mathrm{NO}_{3}$ discharge, and this watershed has the lowest retention of inorganic $\mathrm{N}$ of measured watersheds in the eastern United States (Campbell et al., 2004). In addition, nearby measurements show a significant increase in the importance of sugar maple (a species associated with high rates of $\mathrm{NO}_{3}$ production) through time (Schuler and Gillespie, 2000). Thus, long-term data sets for WS 4 afford the unique opportunity to assess the potential impact of changes in stand species composition on stream water $\mathrm{NO}_{3}$ loss and $\mathrm{N}$ saturation.

Two ways in which changes in tree species composition could impact $\mathrm{N}$ retention are when tree species differ in their rates of total $\mathrm{N}$ uptake, and when they rely on different forms of $\mathrm{N}$ to meet their nutritional requirements. Relatively slow-growing Fagus and 
Quercus species, as well as coniferous species, tend to have lower rates of total $\mathrm{N}$ uptake, while other species, including A. saccharum and European Fraxinus and Tilia species, have higher rates of $\mathrm{N}$ uptake (Jacob and Leuschner, 2014; McFarlane and Yanai, 2006; Schulz et al., 2011; Templer and Dawson, 2004). Therefore, should species with different $\mathrm{N}$ uptake requirements become more, or less, abundant, the overall stand demand for $\mathrm{N}$ could shift and alter watershed $\mathrm{N}$ retention. Similarly, differences among species with respect to the mineral forms of $\mathrm{N}$ they prefer could also affect watershed $\mathrm{N}$ retention if the composition of tree species is altered. A few studies have examined the mineral $\mathrm{N}$ form preference of trees, and their results indicate that the relative uptake of different forms of $\mathrm{N}$ varies from species that rely mostly on $\mathrm{NO}_{3}$ (Rennenberg et al. 2010), to species that prefer $\mathrm{NH}_{4}$ (DesRochers et al. 2007, Buchmann et al. 1995, Gessler et al. $1998,2005)$, to species that change their preference to the form that is most available (Gallet-Budynek et al., 2009; Malagoli et al., 2000). More specifically, previous research has found that Acer saccharum trees, which are often abundant in northeastern and Appalachian deciduous forests, may have a strong preference for $\mathrm{NH}_{4}$ (BassiriRad et al., 1999; Eddy et al., 2008; Lovett and Mitchell, 2004; Rothstein et al., 1996; Templer and Dawson, 2004). While many other trees also preferentially take up $\mathrm{NH}_{4}$, some acquire most of their $\mathrm{N}$ as $\mathrm{NO}_{3}$ (Schulz et al., 2011). Indeed, seedlings of several species found in central Appalachian forests (Fagus grandifolia, Tsuga canadensis, Quercus rubra, and Betula lenta) have been shown to either take up more $\mathrm{NO}_{3}$ than $\mathrm{NH}_{4}$ (Templer and Dawson, 2004), or grow better under $\mathrm{NO}_{3}$ additions (Crabtree and Bazzaz, 1993). Thus, both the total uptake of $\mathrm{N}$ and the potential variability in relative uptake of different 
mineral $\mathrm{N}$ forms by overstory trees could impact $\mathrm{NO}_{3}$ losses following shifts in stand species composition.

In light of the variation between species in both total $\mathrm{N}$ uptake and relative utilization of different mineral forms, it is interesting that the importance of $A$. saccharum has increased substantially over the past century in the FEF (Schuler and Gillespie, 2000). Since studies of this species indicate that they strongly prefer $\mathrm{NH}_{4}$, a shift towards a greater influence of $A$. saccharum on the overall community could partially explain the significant increase in stream water $\mathrm{NO}_{3}$ exhibited in FEF WS 4 - provided the species it replaces preferentially utilizes $\mathrm{NO}_{3}$. In addition, A. saccharum in the FEF is associated with soils with higher $\mathrm{NO}_{3}$ production rates and solution concentrations at individual tree, plot, and watershed scales (Peterjohn et al., 2015). These combined effects indicate that shifts in species composition and stand $\mathrm{NO}_{3}$ utilization may have contributed to changes in stream $\mathrm{NO}_{3}$ export through time.

In this study, we take advantage of the long-term stand inventory and stream water chemical data at the FEF, and couple these data with in situ measurements of $\mathrm{NO}_{3}$ versus $\mathrm{NH}_{4}$ preference of dominant adult, overstory tree species in central Appalachian forests. This combination of data is then used to estimate total $\mathrm{N}$ uptake and temporal changes in stand composition to evaluate the hypothesis that the species composition at this site has shifted towards trees with reduced uptake of $\mathrm{NO}_{3}$, contributing to greater $\mathrm{NO}_{3}$ export from the watershed in stream water. 


\subsection{Methods}

Study site

The focus of this study was a long-term reference watershed and a nearby untreated stand at the FEF. The reference watershed (WS 4) is 39 ha at an average elevation of $792 \mathrm{~m}$ and has a southeastern aspect. The predominant soil type is a Calvin channery silt loam (loamy-skeletal, mixed, mesic Typic Dystrochrept), and the average annual precipitation is $\sim 145 \mathrm{~cm}$ (Kochenderfer, 2006). The forest in WS 4 - and the entire FEF - was heavily cut around 1905-1910, and since that time it has been left uncut and untreated. WS 4 is dominated by temperate broadleaf trees, with Quercus spp., Acer spp., Liriodendron tulipifera, and Prunus serotina making up $>75 \%$ of the tree stems. Continuous stream flow measurements for WS 4 began in 1951 (Reinhart et al., 1963), and weekly or biweekly stream water samples have been analyzed for $\mathrm{NO}_{3}$ concentration since 1970 (Kochenderfer, 2006). From 1975 through 1984, $\mathrm{NO}_{3}$ discharge in stream water increased by $5.6 \mathrm{~kg} \mathrm{~N} \mathrm{ha}^{-1} \mathrm{yr}^{-1}(\sim 435 \%)$; since that time, $\mathrm{NO}_{3}$ levels have remained elevated, with regular $\sim 5-10$ year oscillations (Figure 2-1). Historically, the area has received high rates of $\mathrm{N}$ deposition (Figure 2-2), with total (wet + dry) deposition estimated to be $\sim 10 \mathrm{~kg} \mathrm{~N}$ ha $^{-1}$ year $^{-1}$ from 1986-2002 (Peterjohn et al., 2015). To avoid affecting the $\delta^{15} \mathrm{~N}$ of the long-term reference watershed, we used a "test area" located in a nearby untreated area of the FEF $\left(<1 \mathrm{~km}\right.$ from WS 4) to measure the relative uptake of $\mathrm{NO}_{3}$ versus $\mathrm{NH}_{4}$. This area has a similar elevation, slope, and composition to WS 4, and an east-northeasterly aspect. Unlike WS 4 small, 0.2-ha plots in this portion of the FEF were harvested to selected 
basal areas in the 1980s. However, for this study we selected trees in an area with no surrounding signs of harvest, and the trees selected were of similar size to those in WS 4 .

\section{Species composition and stand $N$ uptake}

Complete inventories of all trees in WS 4, including the total number of live trees of all species in 2-inch diameter at breast height (DBH) categories, were completed by the US Forest Service in 1959, 1964, 1972, 1984, and 2001 (Schuler and Wood, 2015). To investigate changes in species composition, we calculated relative importance value (RIV) for each species in each inventory year as the average of its relative abundance (stems of that species divided by total number of tree stems) and its relative basal area (basal area of that species divided by total tree basal area).

We estimated the total $\mathrm{N}$ uptake by the trees in WS 4 as the sum of annual $\mathrm{N}$ storage in aboveground woody biomass and annual $\mathrm{N}$ return to the soil via litterfall. Complete forest inventory data (1959-2001) were used to estimate annual woody N storage, and since these were $100 \%$ live-tree inventories, tree death is accounted for in these measurements and our estimates. To determine the $\mathrm{N}$ concentration in aboveground woody tissue, in the summer of 1998 , trees greater than $8 \mathrm{~cm}$ in DBH were cored in 16 plots (10-m radius) spread evenly throughout WS 4 (Christ et al. 2002). Using these cores, the width of the

last 5 growth rings was measured, and the wood within $1 \mathrm{~cm}$ of the bark was ground and analyzed for $\mathrm{N}$ content by Dumas combustion (Bremner and Mulvaney, 1982) using a Carlo Erba 1500 CNS elemental analyzer. The total aboveground woody biomass of each 
tree was estimated with FEF-specific allometric equations (Brenneman et al., 1978), and annual $\mathrm{N}$ storage was then calculated as the product of annual biomass increment and woody tissue $\mathrm{N}$ content. Using the $\mathrm{DBH}$ and annual $\mathrm{N}$ storage, a regression equation was built to estimate the annual woody $\mathrm{N}$ storage based on the DBH of any tree in the watershed $\left(R^{2}=0.790\right)$ :

$$
\log (\text { annual woody } N \text { storage })=-2.256+2.182 \log (D B H)+a
$$

where $a$ is a species-specific constant based on the average residual for each species (Christ and Peterjohn, unpublished data).

Total autumnal litter fall mass ( September through December) was collected annually beginning in 1988 by the US Forest Service using 25 litter traps throughout the watershed $\left(0.7679 \mathrm{~m}^{2}\right.$ wooden frames with bottoms of $\sim 0.625 \times 0.625 \mathrm{~cm}$-opening metal mesh). Using its relationship with total stand basal area, measured at 13 long-term growth plots in WS 4, and total litterfall in 1989, 1994, 1999, and $2009\left(R^{2}=0.8867\right)$, we estimated the total litterfall for the years of stand inventories prior to the start of the collection of litterfall data $(1959,1964,1972$, and 1984). We then estimated each species' litterfall for all inventory years using the relationships between a tree species' relative importance value (RIV, average of relative basal area and relative density) and the species-specific litterfall totals at 16 plots in 1998 (Christ et al., 2002). Finally, litter N return from 
inventory years was calculated using species-specific litter $\mathrm{N}$ contents measured in the 1998 litterfall collections.

${ }^{15} N$-labeling

At our "test area" in early July 2014, we conducted a ${ }^{15} \mathrm{~N}$-labeling experiment similar to one by performed by McKane et al. (2002) to determine the relative uptake of $\mathrm{NH}_{4} \mathrm{Vs}$. $\mathrm{NO}_{3}$ for 6 major tree species at the FEF: Acer rubrum, A. saccharum, Betula lenta, Liriodendron tulipifera, Quercus rubra, and Prunus serotina. We used pieces of peg board $\left(625 \mathrm{~cm}^{2}\right.$ each, with 10 rows x 10 columns of holes spaced $2.54 \mathrm{~cm}$ apart $)$ to evenly space injections of $3.5 \mathrm{mM}{ }^{15} \mathrm{~N}$ as $\mathrm{K}^{15} \mathrm{NO}_{3}$ in one area ( $1 \mathrm{~mL}$ per hole), and 3.5 $\mathrm{mM}{ }^{15} \mathrm{~N}$ as ${ }^{15} \mathrm{NH}_{4} \mathrm{Cl}$ in another area under the canopy (within $\sim 3 \mathrm{~m}$ of the trunk) of five mature trees of each species. The solutions were injected midday at approximately the boundary between organic and mineral soil horizons, a depth of $\sim 3 \mathrm{~cm}$, using a syringe needle with four side ports. After three hours, we harvested fine roots $(<2 \mathrm{~mm}$ diameter $)$ from a depth of $\sim 3 \mathrm{~cm}$ at each injection site, and roots from one unlabeled area under each tree to measure the natural ${ }^{15} \mathrm{~N}$ abundance of root tissue.

All roots were placed on ice after harvest and transported to the lab, where they were soaked in $1 \mathrm{M} \mathrm{CaSO}_{4}$ for $1 \mathrm{~min}$ to remove unassimilated $\mathrm{N}$ from the Donnan free space (Thornton et al., 2007). They were then dried at $65^{\circ} \mathrm{C}$ for 48 hours and ground to a fine powder in a dental amalgamator (Henry Schein, Inc., Melville, NY). Approximately $5 \mathrm{mg}$ of each sample were wrapped in tin capsules and analyzed for $\delta^{15} \mathrm{~N}$ via isotope ratio gas 
chromatography-mass spectrometry at the Central Appalachian Stable Isotope Facility that is part of the University of Maryland Center for Environmental Science Appalachian Laboratory (Frostburg, MD, USA).

We calculated root uptake of ${ }^{15} \mathrm{~N}$ from the labeled $\mathrm{N}$ pool as described in Burnham et al. (2017). We first converted $\delta^{15} \mathrm{~N}$ values to the fraction of the heavy isotope in the sample $(F)$ using the ${ }^{15} \mathrm{~N} /{ }^{14} \mathrm{~N}$ ratio in each sample $\left(R_{\text {sample }}\right)($ Fry, 2006):

$$
\begin{gathered}
R_{\text {sample }}=\left(\left(\frac{\delta^{15} N}{1000}\right) * R_{\text {std }}\right)+R_{\text {std }} \\
F=\frac{R_{\text {sample }}}{1+R_{\text {sample }}}
\end{gathered}
$$

where $R_{\text {std }}={ }^{15} \mathrm{~N} /{ }^{14} \mathrm{~N}$ ratio in atmospheric $\mathrm{N}_{2}(0.0036764)$. Using the root tissue $\mathrm{N}$ content and $F$, we calculated the $\mu \mathrm{mol}{ }^{15} \mathrm{~N} \mathrm{~g}^{-1}$ root, and then estimated the rate of ${ }^{15} \mathrm{~N}$ uptake from the ${ }^{15} \mathrm{~N}$ labeled pools by dividing the ${ }^{15} \mathrm{~N}$ excess $\left({ }^{15} \mathrm{~N}\right.$ content of labeled - unlabeled roots from the same tree) by the exposure time ( $3 \mathrm{hrs})$. Finally, we calculated total uptake of ${ }^{15} \mathrm{~N}$ label $\left({ }^{15} \mathrm{NH}_{4}{ }^{+}+{ }^{15} \mathrm{NO}_{3}{ }^{-}\right)$and the percent that was taken up as $\mathrm{NH}_{4}{ }^{+}$and $\mathrm{NO}_{3}{ }^{-}$.

\section{Data analysis}

Our overall ${ }^{15} \mathrm{~N}$-label study design included six species, and five trees per species, with a measurement of $\mathrm{NO}_{3}$ vs. $\mathrm{NH}_{4}$ uptake associated with each tree. We used a nested ANOVA with a Tukey's HSD post-hoc test $(\alpha=0.05)$ to determine if the percent of total $\mathrm{N}$ taken up as $\mathrm{NO}_{3}$ varied by species. The model included the effect of tree nested within 
species. We then performed one-tailed t-tests to determine if the contribution of $\mathrm{NO}_{3}$ to total uptake of $\mathrm{N}$ from the labeled pool was greater than $50 \%$, which would indicate a significant preference of $\mathrm{NO}_{3}$ over $\mathrm{NH}_{4}$.

\subsection{Results}

From 1959 to 2001, total stand density in WS 4 decreased 18\% (from 372 to 305 trees ha

${ }^{1}$ ) and total stand basal area increased 45\% (from 24.3 to $35.2 \mathrm{~m}^{2} \mathrm{ha}^{-1}$ ). In 2001, eight species accounted for $\sim 85 \%$ of the stand composition $(84.6 \%$ of stems and $85.8 \%$ of basal area): Quercus rubra, Q. prinus, Acer saccharum, A. rubrum, Liridendron tulipifera, Prunus serotina, Betula lenta, and Fagus grandifolia. Over the study period, five of these species increased in RIV, and three decreased (Figure 2-3). The RIVs of $A$. saccharum and A. rubrum increased 5.8 and $8.5 \%$, respectively, the most of any species. While the RIV of $A$. saccharum increased, its relative basal area decreased slightly (1.4\%) while the number of stems increased substantially (from $8.9 \%$ to $21.9 \%$ ) throughout the period examined. The RIV of $Q$. rubra increased to a more modest degree $(2.9 \%)$, with its relative basal area increasing from $22.6 \%$ to $32.3 \%$ and its relative abundance decreasing from $20.4 \%$ to $16.7 \%$ throughout the study period. The RIV of $Q$. prinus, B. lenta, and F. grandifolia all declined through the study period (Figure 2-3). The RIV of Q. prinus fell from $6.8 \%$ to $5.6 \%$, and the RIV of $B$. lenta fell from $6.9 \%$ to $3.8 \%$. While there was only a slight decline in the RIV of $F$. grandifolia, from $4.1 \%$ to $3.7 \%$, its relative basal area fell from $5.4 \%$ of the stand to $3.4 \%$, but its relative abundance increased from $2.8 \%$ to $4.0 \%$. 
Aboveground woody $\mathrm{N}$ storage increased from 6.4 to $9.8 \mathrm{~kg} \mathrm{~N} \mathrm{ha}^{-1} \mathrm{yr}^{-1}(53.5 \%)$ and litter $\mathrm{N}$ return increased from 34.5 to $37.6 \mathrm{~kg} \mathrm{~N} \mathrm{ha}^{-1} \mathrm{yr}^{-1}(8.8 \%)$ over this period. In total, stand $\mathrm{N}$ uptake increased from $40.9 \mathrm{~kg} \mathrm{~N} \mathrm{ha}^{-1} \mathrm{yr}^{-1}$ in 1959 to $47.4 \mathrm{~kg} \mathrm{~N} \mathrm{ha}^{-1} \mathrm{yr}^{-1}$ in 2001 (15.8\%). The percent of mineral $\mathrm{N}$ uptake as $\mathrm{NO}_{3}$ ranged from $52.7 \%$ (L. tulipifera) to 75.3\% (A. rubrum), but did not significantly differ between species (Table 2-1). When these rates of $\mathrm{NO}_{3} \mathrm{vs}$. $\mathrm{NH}_{4}$ uptake were applied to the estimates of total $\mathrm{N}$ uptake within the watershed, $\mathrm{NO}_{3}$ uptake increased from 24.5 to $28.8 \mathrm{~kg} \mathrm{~N} \mathrm{ha}^{-1} \mathrm{yr}^{-1}$ (17.2\%) and $\mathrm{NH}_{4}$ uptake increased from 16.4 to $18.6 \mathrm{~kg} \mathrm{~N} \mathrm{ha}^{-1} \mathrm{yr}^{-1}$ (13.7\%) from 1959 to 2001 . The percent of total stand uptake of $\mathrm{N}$ taken up as $\mathrm{NO}_{3}$ thus increased $0.7 \%$.

Prior studies, using other methods and some using more sampling dates, found much lower rates of $\mathrm{N}$ uptake as $\mathrm{NO}_{3}$ by $A$. saccharum (average of $15.8 \%$, vs. $53.6 \%$ in this study) (Table 2-2). Given the range of values reported for the affinity of $A$. saccharum for $\mathrm{NO}_{3}$, we assessed the potential impact that changes in the importance of this particular species might have on stand uptake of $\mathrm{NO}_{3}$. We considered two scenarios. First, we used the average of prior studies' relative contribution of $\mathrm{NO}_{3}$ to tree uptake of $\mathrm{N}(15.8 \%)$. Second, we used the average of all available estimates of the uptake of $\mathrm{N}$ as $\mathrm{NO}_{3}$ by $A$. saccharum, including our in situ ${ }^{15} \mathrm{~N}$-labeling results, which raised the average to $23.4 \%$. To estimate stand uptake of $\mathrm{NO}_{3}$, we used the average of our measured values of $\mathrm{N}$ uptake as $\mathrm{NO}_{3}$ for the other species. For the first scenario, when the average rate of $\mathrm{NO}_{3}$ vs. $\mathrm{NH}_{4}$ uptake for $A$. saccharum from previous studies was applied to the estimates of total $\mathrm{N}$ uptake within WS 4 at the FEF, $\mathrm{NO}_{3}$ uptake increased $3.7 \mathrm{~kg} \mathrm{~N}^{-1} \mathrm{yr}^{-1}(15.7 \%)$ and $\mathrm{NH}_{4}$ uptake increased $2.8 \mathrm{~kg} \mathrm{~N} \mathrm{ha}^{-1} \mathrm{yr}^{-1}(15.8 \%)$ from 1959 to 2001 . Under this 
scenario, the percent of total stand uptake of $\mathrm{N}$ as $\mathrm{NO}_{3}$ decreased slightly $(-0.01 \%)$

(Figure 2-4). For the second scenario, using the average of all available estimates of $\mathrm{N}$ uptake as $\mathrm{NO}_{3}$, the stand uptake of $\mathrm{NO}_{3}$ increased $3.8 \mathrm{~kg} \mathrm{~N} \mathrm{ha}^{-1} \mathrm{yr}^{-1}(15.7 \%)$ and uptake

of $\mathrm{NH}_{4}$ increased $2.7 \mathrm{~kg} \mathrm{~N} \mathrm{ha}^{-1} \mathrm{yr}^{-1}(15.8 \%)$ from 1959 to 2001 . Thus, the percent of total stand uptake of $\mathrm{N}$ as $\mathrm{NO}_{3}$ increased slightly $(0.1 \%)$ (Figure 2-4).

\subsection{Discussion}

Unexpectedly, the tree species we considered did not differ in their relative uptake of $\mathrm{NH}_{4}$ and $\mathrm{NO}_{3}$ and utilized significant amounts of both forms in their mineral $\mathrm{N}$ nutrition. This is surprising, since prior studies found large differences in the relative $\mathrm{N}$ uptake as $\mathrm{NH}_{4}$ vs. $\mathrm{NO}_{3}$ for temperate forest species (Schulz et al., 2011; Templer and Dawson, 2004). Notably, A. saccharum trees took up substantially less $\mathrm{NO}_{3}$ in past studies than we found using an in situ ${ }^{15} \mathrm{~N}$-labeling technique (Table 2-2) (BassiriRad et al., 1999; Eddy et al., 2008; Rothstein et al., 1996; Templer and Dawson, 2004), and it seems likely that methodological differences could account for the higher relative $\mathrm{NO}_{3}$ uptake in this study (Jacob and Leuschner, 2014). Most of the prior research on mineral $\mathrm{N}$ form uptake utilized seedlings (Templer and Dawson, 2004), hydroponic techniques (Gessler et al., 1998; Kronzucker et al., 1997), or N depletion in a simulated soil solution (Gessler et al., 1998; McFarlane and Yanai, 2006) - techniques that do not account for some aspects of in situ soil $\mathrm{N}$ dynamics. Perhaps most importantly, the differential diffusional resistances of $\mathrm{NH}_{4}$ and $\mathrm{NO}_{3}$ in soils (Chapman et al., 2012) are not represented in hydroponic and simulated soil solution techniques. Thus, even though root uptake kinetics suggest greater 
uptake of $\mathrm{NH}_{4}, \mathrm{NO}_{3}$ may contribute more to $\mathrm{N}$ nutrition of trees than previously thought due to the greater rates of transfer of $\mathrm{NO}_{3}$ to roots in the soil.

Since the species examined did not differ in their relative contribution of $\mathrm{NO}_{3}$ to total $\mathrm{N}$ uptake, it seems unlikely that changes in stand composition contributed to the increase in $\mathrm{NO}_{3}$ discharge from WS 4 via a reduction in the demand by trees for $\mathrm{NO}_{3}$. Assuming no reduction in soil $\mathrm{N}$ storage occurred, it appears that the observed increase in $\mathrm{NO}_{3}$ discharge from WS 4 resulted from an enhanced supply of available $\mathrm{NO}_{3}$, rather than a reduction in biological demand. Although different species have different $\mathrm{N}$ nutritional requirements (Jacob and Leuschner, 2014; McFarlane and Yanai, 2006; Schulz et al., 2011), the changes in species composition did not appear to lead to lower $\mathrm{N}$ demand, nor did the changes contribute to the increase in stream water $\mathrm{N}$ discharge. Instead, stand $\mathrm{N}$ demand increased over the second half of the last century, and may have contributed to the gradual decrease in soil and stream water $\mathrm{NO}_{3}$ since the early 1980s (Gilliam and Adams, 2011). Thus, the increase in stream water $\mathrm{NO}_{3}$ discharge around 1980 appears to be driven mainly by an elevated $\mathrm{N}$ supply.

Although changes in stand $\mathrm{NO}_{3}$ demand do not seem to account for the increase in $\mathrm{NO}_{3}$ discharge in stream water, shifts in stand composition could still impact $\mathrm{NO}_{3}$ production in the soil. At several locations in the eastern U.S., A. saccharum trees are associated with high rates of soil net nitrification and low soil C:N ratios (Lovett and Mitchell, 2004; Pastor et al., 1984; Rothstein et al., 1996; Zak and Pregitzer, 1990), including WS 4 and 
at other locations in the FEF (Christ et al., 2002; Peterjohn et al., 2015). This association is driven, in part, by relatively labile litter and its low $\mathrm{N}$ residence time (Peterjohn et al., 2015; Pregitzer et al., 2010). Using plot-level measurements of net nitrification potential and relative importance value of tree species, we estimate that net nitrification potential increases $0.02 \mathrm{~kg} \mathrm{ha}^{-1}$ day $^{-1}$ for every $1 \%$ increase in $A$. saccharum importance value $\left(\mathrm{R}^{2}\right.$ $=45 \%$ ) and decreases $0.017 \mathrm{~kg} \mathrm{ha}^{-1}$ day $^{-1}$ for every $1 \%$ increase in $\mathrm{A}$. rubrum importance value $\left(\mathrm{R}^{2}=13 \%\right)($ Christ et al., 2002). Since these species had the largest increases in relative importance value from 1959 through 2001, and have opposite associations with net nitrification potential, we assessed their impact on soil $\mathrm{NO}_{3}$ supply and potentially loss in stream water. To arrive at an annual estimate, we assumed that: 1) the full daily rate of change in NNP applied during the months of May through August, 2) only $50 \%$ of the full daily rate was attained during March, April, and September through November, when the rate of nitrification is lower (Gilliam et al., 2001), and 3) the species change had no effect during the months of December through February, when very little nitrification takes place.

Our initial approximation suggests that the effects of $A$. saccharum and A. rubrum on soil $\mathrm{NO}_{3}$ production from 1959 to 2001 offset, with the negative effect of $A$. rubrum on nitrification causing a net overall decrease of $2.6 \mathrm{~kg} \mathrm{NO}_{3}-\mathrm{N} \mathrm{ha}^{-1} \mathrm{yr}^{-1}$ produced within WS 4. However, the majority of the A. rubrum increase occurred in a silvicultural compartment of the watershed that produces very little $\mathrm{NO}_{3}$ in the soil, and that has very low $\mathrm{NO}_{3}$ concentrations in tension-free lysimeters (Peterjohn et al., 1999). Thus, it is unlikely that this region of the WS 4 contributed to the observed temporal change in 
stream $\mathrm{NO}_{3}$ discharge. Additionally, this compartment contains no A. saccharum trees, so a change in the importance of this species would only impact the other two compartments of the watershed, where nitrification and soil $\mathrm{NO}_{3}$ is much higher (Christ et al., 2002; Peterjohn et al., 1999). In light of these known spatial patterns in $\mathrm{NO}_{3}$ availability and species composition, we refined our assessment by restricting it to the two compartments containing $A$. saccharum, which collectively make up $\sim 86 \%$ of WS 4 . Taking this approach, we estimate that the net effect of $A$. saccharum and $A$. rubrum on soil $\mathrm{NO}_{3}$ production was an increase of $3.9 \mathrm{~kg} \mathrm{NO}_{3}-\mathrm{N} \mathrm{ha}^{-1} \mathrm{yr}^{-1}$ from 1959 through 2001 . However, this increase in soil $\mathrm{NO}_{3}$ supply is partially balanced by a $2.4 \mathrm{~kg} \mathrm{NO}_{3}-\mathrm{N} \mathrm{ha}^{-1} \mathrm{yr}^{-1}$ increase in forest $\mathrm{NO}_{3}$ demand in these areas caused by higher A. saccharum and A. rubrum importance values, resulting in a net increase of $1.5 \mathrm{~kg} \mathrm{NO}_{3}-\mathrm{N} \mathrm{ha}^{-1} \mathrm{yr}^{-1}$. This illustrates the potential impact of species composition on soil $\mathrm{N}$ production, which, combined with historically high $\mathrm{N}$ supply via $\mathrm{N}$ deposition, seems to have outweighed the increase in stand $\mathrm{NO}_{3}$ uptake through time and contributed to persistently low inorganic $\mathrm{N}$ retention in this watershed. It also illustrates that understanding the effect of $\mathrm{N}$ deposition on the temporal dynamics of stream water $\mathrm{NO}_{3}$ loss requires a relatively complete understanding of how changes in forest species composition can influence the balance between nutrient supply and demand, and how spatial patterning of the supply/demand balance within a watershed may also be important. 


\subsection{Tables and Figures}

Table 2-1. The percent of total uptake of mineral $\mathrm{N}$ as $\mathrm{NO}_{3}$ for six major overstory trees at the FEF, measured in situ using ${ }^{15} \mathrm{~N}$ labeled $\mathrm{NO}_{3}$ and $\mathrm{NH}_{4}$.

\begin{tabular}{lc}
\hline \multicolumn{1}{c}{ Species } & Percent of $\mathrm{N}$ uptake as $\mathrm{NO}_{3}(\mathrm{SE})$ \\
\hline \hline A. rubrum & $75.3(12.5)$ \\
A. saccharum & $53.6(16.0)$ \\
B. lenta & $54.7(11.5)$ \\
L. tulipifera & $52.7(13.0)$ \\
P. serotina & $61.6(11.3)$ \\
Q. rubra & $56.4(11.5)$ \\
\hline
\end{tabular}


Table 2-2. All available estimates of the percent of total uptake of mineral $\mathrm{N}$ as $\mathrm{NO}_{3}$ and estimated $\mathrm{N}$ uptake rates $\left(\mu \mathrm{mol} \mathrm{NO} \mathrm{N}_{3}-\mathrm{N} g\right.$ dry $\left.\operatorname{root}^{-1} \mathrm{hr}^{-1}\right)$ for A saccharum. Measurement methods and parameters varied by study.

\begin{tabular}{|c|c|c|c|}
\hline Study & Method & $\begin{array}{c}\text { A. saccharum } \mathrm{N} \\
\text { uptake as } \mathrm{NO}_{3}(\%) \\
\end{array}$ & $\begin{array}{l}\text { Estimated uptake rate } \\
\quad\left(\mu \mathrm{mol} \mathrm{N} \mathrm{g} \mathrm{hr}^{-1}\right) \\
\end{array}$ \\
\hline $\begin{array}{l}\text { BassiriRad et al. } \\
\text { (1999) }\end{array}$ & $\begin{array}{l}\text { In situ } \mathrm{N} \text { depletion, } \\
\text { excavated intact roots, } \\
\mathrm{V}_{\max }\end{array}$ & 31 & 9 \\
\hline Eddy et al. (2008) & $\begin{array}{l}\text { Excised root }{ }^{15} \mathrm{~N} \\
\text { uptake, } V_{\max }\end{array}$ & 11.2 & 0.63 \\
\hline $\begin{array}{l}\text { Rothstein et al. } \\
\text { (1996) }\end{array}$ & $\begin{array}{l}\text { Excised root }{ }^{15} \mathrm{~N} \\
\text { uptake, } \mathrm{V}_{\max }\end{array}$ & 3 & 1.0 \\
\hline $\begin{array}{l}\text { Templer and Dawson } \\
\text { (2004) }\end{array}$ & $\begin{array}{l}{ }^{15} \mathrm{~N} \text { addition to } \\
\text { seedlings, greenhouse, } \\
\text { roots in native soil }\end{array}$ & 18 & $1.0^{1}$ \\
\hline This study & $\begin{array}{l}\text { In situ }{ }^{15} \mathrm{~N} \text { addition to } \\
\text { mature trees, roots left } \\
\text { in native soil }\end{array}$ & 53.6 & $11.6^{2}$ \\
\hline \multicolumn{4}{|c|}{${ }^{1}$ estimated using the reported values of root biomass, total plant biomass, and $\mathrm{N}$ uptake per total } \\
\hline \multicolumn{4}{|c|}{${ }^{2}$ estimated assuming that the soil ${ }^{15} \mathrm{~N}$ atom percent after labeling was similar to that of the root } \\
\hline
\end{tabular}




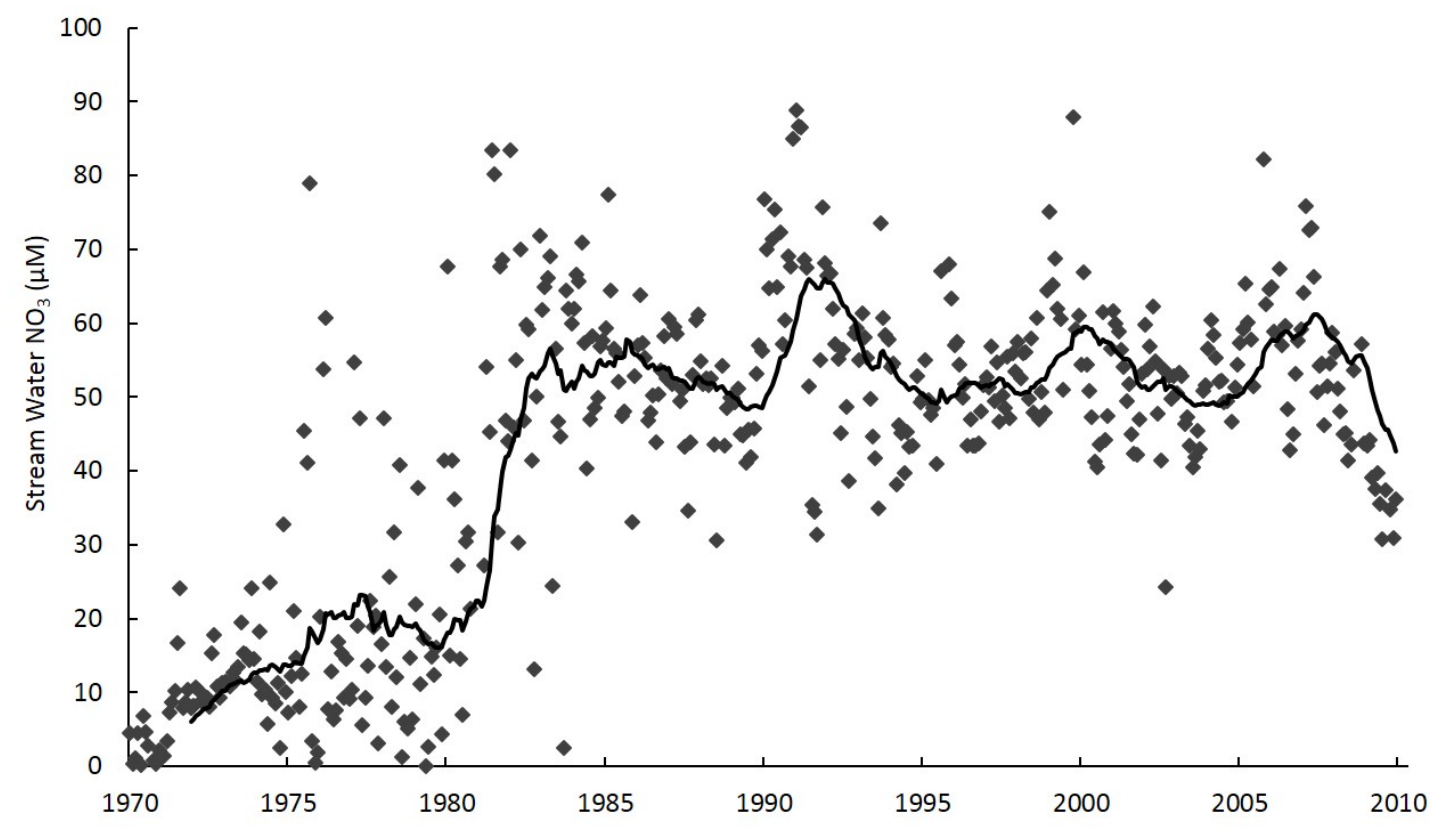

Figure 2-1. Flow-weighted monthly average stream water $\mathrm{NO}_{3}$ concentration through time in FEF WS 4. The trend line is a 24-month running mean to visualize the temporal trend. 


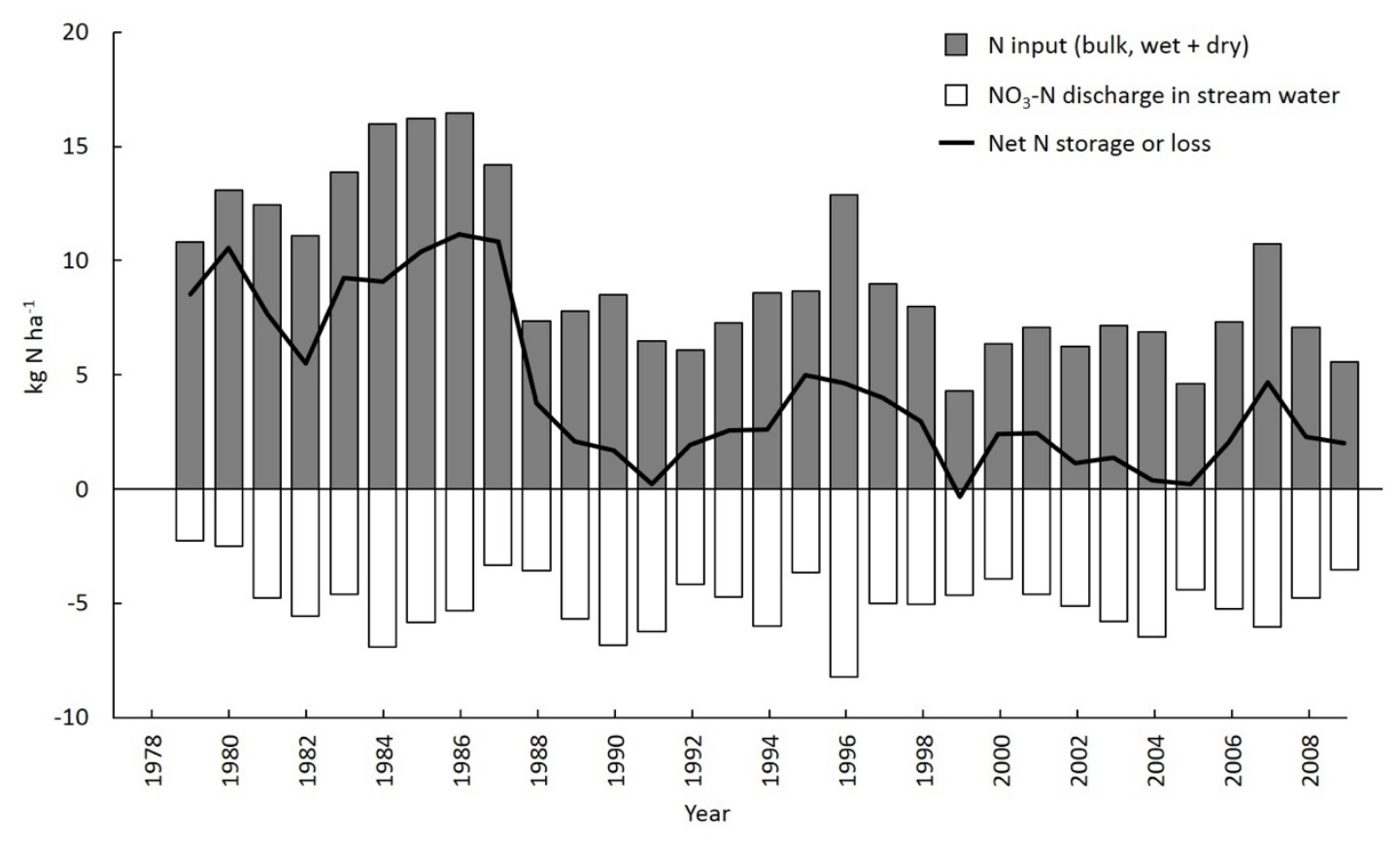

Figure 2-2. Annual bulk (wet + dry) $\mathrm{N}$ inputs into and stream discharge from FEF WS 4, and the net $\mathrm{N}$ storage or loss from the catchment. 

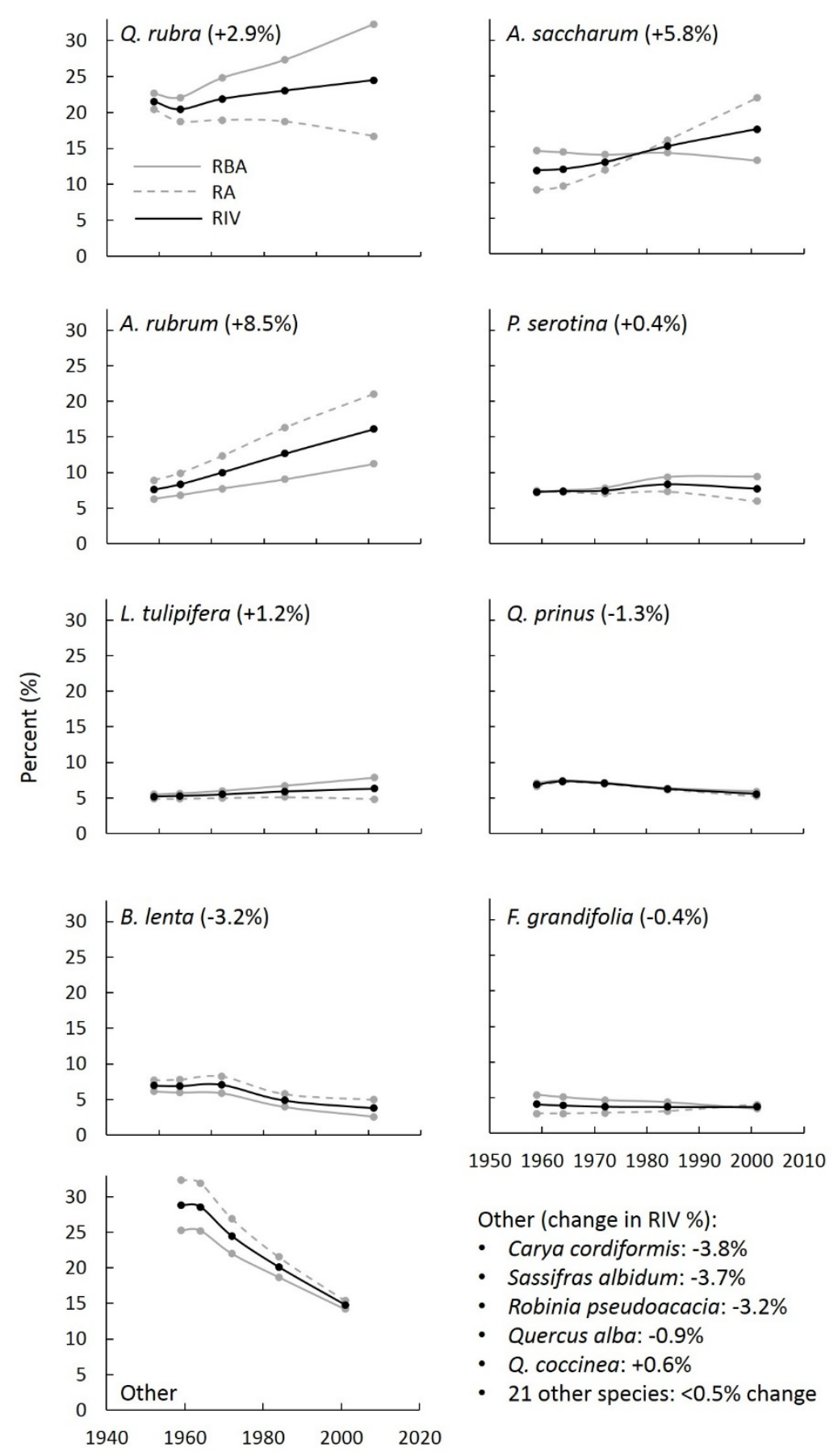

Other (change in RIV \%):

- Carya cordiformis: $-3.8 \%$

- Sassifras albidum: $-3.7 \%$

- Robinia pseudoacacia: $-3.2 \%$

- Quercus alba: $-0.9 \%$

- Q. coccinea: $+0.6 \%$

- 21 other species: $<0.5 \%$ change

Figure 2-3. Tree species' relative importance, abundance, and basal area (\%) in FEF WS 4 from 1959 to 2001. The percent changes for species listed under "other" are changes in RIV. Data from the USDA Forest Service Northern Research Station (Schuler and Wood, 2015). 


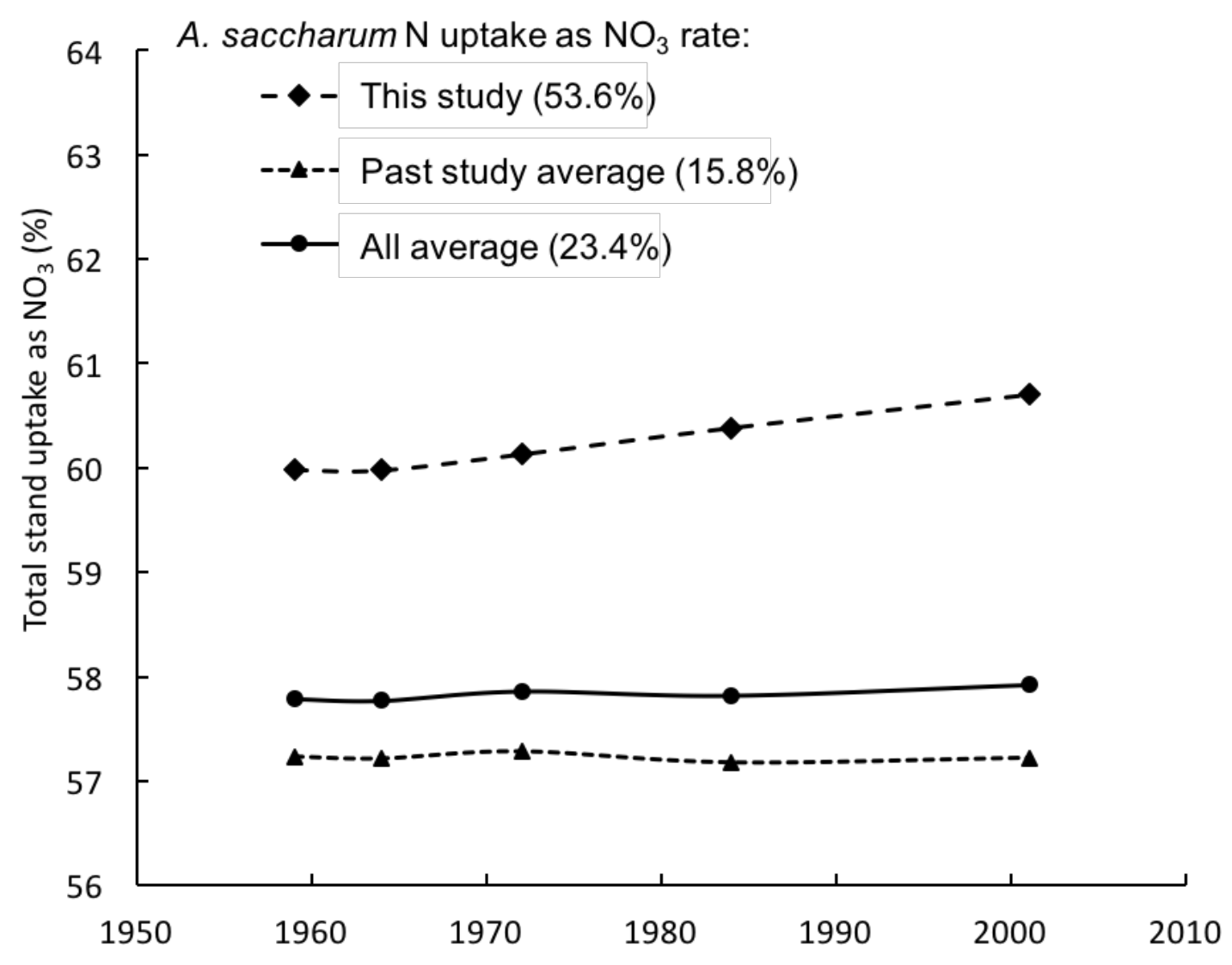

Figure 2-4. The contribution of $\mathrm{NO}_{3}$ to total stand uptake of $\mathrm{N}$ from 1959 to 2001.

Different lines represent different estimates of uptake of $\mathrm{N}^{2} \mathrm{NO}_{3}$ for $A$. saccharum, based on prior studies, this study, and the average of all available rates. 


\subsection{References}

Aber, J., McDowell, W., Nadelhoffer, K., Magill, A., Bernston, G., Kamakea, M., McNulty, S., Currie, W., Rustad, L., Fernandez, I., 1998. Nitrogen saturation in temperate forest ecosystems. Bioscience 48, 921-934.

Adams, M.B., Angradi, T.R., Kochenderfer, J.N., 1997. Stream water and soil solution responses to 5 years of nitrogen and sulfur additions at the Fernow Experimental Forest, West Virginia. For. Ecol. Manage. 95, 79-91.

Argerich, A., Johnson, S.L., Sebestyen, S.D., Rhoades, C.C., Greathouse, E., Knoepp, J.D., Adams, M.B., Likens, G.E., Campbell, J.L., McDowell, W.H., Scatena, F.N., Ice, G.G., 2013. Trends in stream nitrogen concentrations for forested reference catchments across the USA. Environ. Res. Lett. 8, 1-8. doi:10.1088/1748$9326 / 8 / 1 / 014039$

BassiriRad, H., Prior, S., Norby, R., Rogers, H., 1999. A field method of determining $\mathrm{NH}_{4}{ }^{+}$and $\mathrm{NO}_{3}{ }^{-}$uptake kinetics in intact roots: Effects of $\mathrm{CO}_{2}$ enrichment on trees and crop species. Plant Soil 217, 195-204.

Boggs, J.L., Mcnulty, S.G., Gavazzi, M.J., Myers, J.M., 2005. Tree growth, foliar chemistry, and nitrogen cycling across a nitrogen deposition gradient in southern Appalachian deciduous forests. Can. J. For. Res. 35, 1901-1913. doi:10.1139/X05128

Bormann, F.H., Likens, G.E., Fisher, D.W., Pierce, R.S., 1968. Nutrient loss accelerated by clear-cutting of a forest ecosystem. Science $159,882-884$.

doi:10.1126/science.159.3817.882 
Bremner, J.M., Mulvaney, C.S., 1982. N - total, in: Page, A.L. (Ed.), Methods of Soil Analysis. Part 2. American Society of Agronomy and Soil Science Society of America, Madison, WI, USA, pp. 595-624.

Brenneman, B., Frederick, D., Gardner, W., Schoenhofen, L., Marsh, P., 1978. Biomass of species and stands of West Virginia hardwoods, in: Proceedings 2nd Central Hardwood Forest Conference. West Lafayette, IN, pp. 159-178.

Burnham, M.B., Cumming, J.R., Adams, M.B., Peterjohn, W.T., 2017. Soluble soil aluminum alters the relative uptake of mineral nitrogen forms by six mature temperate broadleaf tree species: possible implications for watershed nitrate retention. Oecologia 185, 327-337. doi:10.1007/s00442-017-3955-8

Campbell, J.L., Hornbeck, J.W., Mitchell, M.J., Adams, M.B., Castro, M.S., Driscoll, C.T., Kahl, J.S., Kochenderfer, J.N., Likens, G.E., Lynch, J.A., Murdoch, P.S., Nelson, S.J., Shanley, J.B., 2004. Input-output budgets of inorganic nitrogen for 24 forest watersheds in the northeastern United States: A review. Water. Air. Soil Pollut. 151, 373-396.

Chapman, N., Miller, A.J., Lindsey, K., Whalley, W.R., 2012. Roots, water, and nutrient acquisition: Let's get physical. Trends Plant Sci. 17, 701-710. doi:10.1016/j.tplants.2012.08.001

Christ, M., Peterjohn, W., Cumming, J., Adams, M., 2002. Nitrification potentials and landscape, soil and vegetation characteristics in two Central Appalachian watersheds differing in NO3- export. For. Ecol. Manage. 159, 145-158. 
Christ, M.J., Peterjohn, W.T., Cumming, J.R., Adams, M.B., 2002. Nitrification potentials and landscape, soil and vegetation characteristics in two Central Appalachian watersheds differing in $\mathrm{NO}_{3}{ }^{-}$export. For. Ecol. Manage. 159, 145-158. doi:10.1016/S0378-1127(00)00725-8

Crabtree, R., Bazzaz, F., 1993. Seedling response of four birch species to simulated nitrogen deposition: Ammonium vs. nitrate. Ecol. Appl. 3, 315-321.

Davidson, E.A., Chorover, J., Dail, D.B., 2003. A mechanism of abiotic immobilization of nitrate in forest ecosystems: The ferrous wheel hypothesis. Glob. Chang. Biol. 9, 228-236. doi:10.1046/j.1365-2486.2003.00592.x

Driscoll, C.T., Lawrence, G.B., Bulger, A.J., Butler, T.J., Cronan, C.S., Eagar, C., Lambert, K.F., Likens, G.E., Stoddard, J.L., Weathers, K.C., 2001. Acidic deposition in the northeastern United States: Sources and inputs, ecosystems effects, and management strategies. Bioscience 51, 180-198. doi:10.1641/00063568(2001)051[0180:ADITNU]2.0.CO;2

Eddy, W.C., Zak, D.R., Holmes, W.E., Pregitzer, K.S., 2008. Chronic Atmospheric $\mathrm{NO}_{3}{ }^{-}$ Deposition Does Not Induce $\mathrm{NO}_{3}{ }^{-}$Use by Acer saccharum Marsh. Ecosystems 11, 469-477. doi:10.1007/s10021-008-9134-3

Edwards, P.J., Williard, K.W.J., Wood, F., Sharpe, W.E., 2006. Soil water and stream water chemical responses, in: Adams, M., DeWalle, D., Hom, J. (Eds.), The Fernow Watershed Acidification Study. Springer, Dordrecht, pp. 71-136. 
Fahey, T.J., Hughes, J.W., Pu, M., Arthur, M.A., 1988. Root decomposition and nutrient flux following whole-tree harvest of northern hardwood forest. For. Sci. 34, 744768.

Fahey, T.J., Siccama, T.G., Driscoll, C.T., Likens, G.E., Campbell, J., Johnson, C.E., Battles, J.J., Aber, J.D., Cole, J.J., Fisk, M.C., Groffman, P.M., Hamburg, S.P., Holmes, R.T., Schwarz, P.A., Yanai, R.D., 2005. The biogeochemistry of carbon at Hubbard Brook. Biogeochemistry 75, 109-176. doi:10.1007/s10533-004-6321-y

Fenn, M.E., Poth, M.A., Aber, J.D., Baron, J.S., Bormann, B.T., Johnson, D.W., Lemly, A.D., Mcnulty, S.G., Ryan, D.F., Stottlemyer, R., 1998. Nitrogen excess in North American ecosystems: Predisposing factors, ecosystem responses, and management strategies. Ecol. Appl. 8, 706-733.

Foster, C.J., 1997. The variable response of two central Appalachian forests to high inputs of atmospheric nitrogen: a study of neighboring watersheds in Fernow Experimental Forest, West Virginia. Master's Thesis, West Virginia University.

Fry, B., 2006. Stable Isotope Ecology, 1st ed. Springer, New York.

Gallet-Budynek, A., Brzostek, E., Rodgers, V.L., Talbot, J.M., Hyzy, S., Finzi, A.C., 2009. Intact amino acid uptake by northern hardwood and conifer trees. Oecologia 160, 129-138. doi:10.1007/s00442-009-1284-2

Galloway, J., Dentener, F., Capone, D., Boyer, E., Howarth, R., Seitzinger, S., Asner, G., Cleveland, C., Green, P., Holland, E., Karl, D., Michaels, A., Porter, J., Townsend, A., Vorosmarty, C., 2004. Nitrogen cycles: past, present, and future. Biogeochemistry 70, 153-226. 
Gessler, A., Schneider, S., Sengbusch, D. Von, Weber, P., Haneman, U., Huber, C., Rothe, A., Kreutzer, K., Rennenberg, H., 1998. Field and laboratory experiments on net uptake of nitrate and ammonium by the roots of spruce (Picea abies) and beech (Fagus sylvatica) trees. New Phytol. 138, 275-285.

Gilliam, F.S., Adams, M.B., 2011. Effects of nitrogen on temporal and spatial patterns of nitrate in streams and soil solution of a central hardwood forest. ISRN Ecol. 2011, 1-9. doi:10.5402/2011/138487

Gilliam, F.S., Yurish, B.M., Adams, M.B., 2001. Temporal and spatial variation of nitrogen transformations in nitrogen-saturated soils of a central Appalachian hardwood forest. Can. J. For. Res. 31, 1768-1785. doi:10.1139/cjfr-31-10-1768

Goodale, C.L., Fredriksen, G., Weiss, M.S., McCalley, C.K., Sparks, J.P., Thomas, S.A., 2015. Soil processes drive seasonal variation in retention of ${ }^{15} \mathrm{~N}$ tracers in a deciduous forest catchment. Ecology 96, 2653-2668.

Jacob, A., Leuschner, C., 2014. Complementarity in the use of nitrogen forms in a temperate broad-leaved mixed forest. Plant Ecol. Divers. 1-16. doi:10.1080/17550874.2014.898166

Kochenderfer, J.N., 2006. Fernow and the Appalachian Hardwood Region, in: Adams, M., DeWalle, D., Hom, J. (Eds.), The Fernow Watershed Acidification Study. Springer, Dordrecht, pp. 17-39.

Kronzucker, H.J., Siddiqi, M.Y., Glass, A.D.M., 1997. Conifer root discrimination against soil nitrate and the ecology of forest succession. Nature 385, 59-61. 
Likens, G.E., Buso, D.C., 2012. Dilution and the elusive baseline. Environ. Sci. Technol. 46, 4382-4387. doi:10.1021/es3000189

Lovett, G., Mitchell, M., 2004. Sugar maple and nitrogen cycling in the forests of Eastern North America. Front. Ecol. Environ. 2, 81-88.

Lovett, G.M., Weathers, K.C., Arthur, M.A., Schultz, J.C., 2004. Nitrogen cycling in a northern hardwood forest: Do species matter? Biogeochemistry 67, 289-308. doi:10.1023/B:BIOG.0000015786.65466.f5

Malagoli, M., Canal, A.D., Quaggiotti, S., Pegoraro, P., Bottacin, A., 2000. Differences in nitrate and ammonium uptake between Scots pine and European larch. Plant Soil $221,1-3$.

McFarlane, K.J., Yanai, R.D., 2006. Measuring nitrogen and phosphorus uptake by intact roots of mature Acer saccharum Marsh., Pinus resinosa Ait., and Picea abies (L.) Karst. Plant Soil 279, 163-172. doi:10.1007/s11104-005-0838-2

McKane, R.B., Johnson, L.C., Shaver, G.R., Nadelhoffer, K.J., Rastetter, E.B., Fry, B., Giblin, A.E., Kielland, K., Kwiatkowski, B.L., Laundre, J. a, Murray, G., 2002. Resource-based niches provide a basis for plant species diversity and dominance in arctic tundra. Nature 415, 68-71. doi:10.1038/415068a

McLauchlan, K.K., Craine, J.M., Oswald, W.W., Leavitt, P.R., Likens, G.E., 2007. Changes in nitrogen cycling during the past century in a northern hardwood forest. Proc. Natl. Acad. Sci. U. S. A. 104, 7466-70. doi:10.1073/pnas.0701779104 
Nadelhoffer, K., Downs, M., Fry, B., Magill, A., Aber, J., 1999. Controls on N retention and exports in a forested watershed. Environ. Monit. Assess. doi:10.1023/A:1006190222768

Nadelhoffer, K.J., Emmett, B. a., Gundersen, P., Kjønaas, O.J., Koopmans, C.J., Schleppi, P., Tietema, A., Wright, R.F., 1999. Nitrogen deposition makes a minor contribution to carbon sequestration in temperate forests. Nature 398, 145-148. doi:10.1038/18205

Pastor, J., Aber, J.D., Mcclaugherty, C.A., Melillo, J.M., 1984. Aboveground production and $\mathrm{N}$ and $\mathrm{P}$ cycling along a nitrogen mineralization gradient on Blackhawk Island, Wisconsin. Ecology 65, 256-268. doi:10.2307/1939478

Peterjohn, W.T., Adams, M.B., Gilliam, F.S., 1996. Symptoms of nitrogen saturation in two central Appalachian hardwood forest ecosystems. Biogeochemistry 35, 507522.

Peterjohn, W.T., Foster, C.J., Christ, M.J., Adams, M.B., 1996. Patterns of nitrogen availability within a forested watershed exhibiting symptoms of nitrogen saturation. Forest Ecology and Management 119, 247-257.

Peterjohn, W.T., Harlacher, M.A., Christ, M.J., Adams, M.B., 2015. Testing associations between tree species and nitrate availability: Do consistent patterns exist across spatial scales? For. Ecol. Manage. 358, 335-343. doi:10.1016/j.foreco.2015.09.018

Pregitzer, K.S., Zak, D.R., Talhelm, A.F., Burton, A.J., Eikenberry, J.R., 2010. Nitrogen turnover in the leaf litter and fine roots of sugar maple. Ecology 91, 3456-3462. doi:10.1890/10-0633.1 
Reinhart, K., Eschner, A., Trimble, G., 1963. Effect on streamflow of four forest practices in the mountains of West Virginia, US Forest Service Research Paper NEI.

Rose, L., Sebestyen, S., Elliott, E., Koba, K., 2015. Drivers of atmospheric nitrate processing and export in forested catchments. Water Resour. Res. 51, 1333-1352. doi:10.1002/2014WR015716

Rothstein, D.E., Zak, D.R., Pregitzer, K.S., Url, S., Zak, R., 1996. Nitrate deposition in northern hardwood forests and the nitrogen metabolism of Acer saccharum Marsh. Oecologia 108, 338-344.

Schuler, T., Gillespie, A., 2000. Temporal patterns of woody species diversity in a central Appalachian forest from 1856 to 1997. J. Torrey Bot. Soc. 127, 149-161.

Schuler, T., Wood, F., 2015. Fernow Experimental Forest watershed 4 overstory tree data, 1959-2001. Parsons, WV: U.S. Department of Agriculture, Forest Service, Northern Research Station.

Schulz, H., Härtling, S., Stange, C.F., 2011. Species-specific differences in nitrogen uptake and utilization by six European tree species. J. Plant Nutr. Soil Sci. 174, 28 37. doi:10.1002/jpln.201000004

Skjelkvåle, B.L., Stoddard, J.L., Jeffries, D.S., Tørseth, K., Høgåsen, T., Bowman, J., Mannio, J., Monteith, D.T., Mosello, R., Rogora, M., Rzychon, D., Vesely, J., Wieting, J., Wilander, A., Worsztynowicz, A., 2005. Regional scale evidence for improvements in surface water chemistry 1990-2001. Environ. Pollut. 137, 165-176. doi:10.1016/j.envpol.2004.12.023 
Templer, P.H., Dawson, T.E., 2004. Nitrogen uptake by four tree species of the Catskill Mountains, New York: implications for forest N dynamics. Plant Soil 262, 251-261. doi:10.1023/B:PLSO.0000037047.16616.98

Templer, P.H., Lovett, G.M., Weathers, K.C., Findlay, S.E., Dawson, T.E., 2005. Influence of tree species on forest nitrogen retention in the Catskill Mountains, New York, USA. Ecosystems 8, 1-16. doi:10.1007/s10021-004-0230-8

Thornton, B., Osborne, S.M., Paterson, E., Cash, P., 2007. A proteomic and targeted metabolomic approach to investigate change in Lolium perenne roots when challenged with glycine. J. Exp. Bot. 58, 1581-1590. doi:10.1093/jxb/erl294

Zak, D.R., Pregitzer, K.S., 1990. Spatial and temporal variability of nitrogen cycling in northern Lower Michigan. For. Sci. 36, 367-380. 
Chapter 3. Soluble soil aluminum alters the relative uptake of mineral nitrogen forms by six mature temperate broadleaf tree species: Possible implications for watershed nitrate retention

Reprinted from

Burnham MB, Cumming JR, Adams MB, Peterjohn WT. (2017) Soluble soil aluminum alters the relative uptake of mineral nitrogen forms by six mature temperate broadleaf tree species: Possible implications for watershed nitrate retention. Oecologia 185(3):327-337. DOI: $10.1007 / \mathrm{s} 00442-017-3955-8$

*Minor modifications incorporated at the request of committee members. 


\subsection{Abstract}

Increased availability of monomeric aluminum $\left(\mathrm{Al}^{3+}\right)$ in forest soils is an important adverse effect of acidic deposition that reduces root growth and inhibits nutrient uptake. There is evidence that $\mathrm{Al}^{3+}$ exposure interferes with $\mathrm{NO}_{3}{ }^{-}$uptake. If true for overstory trees, the reduction in stand demand for $\mathrm{NO}_{3}{ }^{-}$could increase $\mathrm{NO}_{3}{ }^{-}$discharge in stream water. These effects may also differ between species that tolerate different levels of soil acidity. To examine these ideas, we measured changes in relative uptake of $\mathrm{NO}_{3}{ }^{-}$and $\mathrm{NH}_{4}{ }^{+}$by six tree species in situ under increased soil $\mathrm{Al}^{3+}$ using a ${ }^{15} \mathrm{~N}$-labeling technique, and measured soluble soil $\mathrm{Al}$ levels in a separate wholewatershed acidification experiment in the Fernow Experimental Forest (WV). When exposed to added $\mathrm{Al}^{3+}$, the proportion of inorganic $\mathrm{N}$ acquired as $\mathrm{NO}_{3}{ }^{-}$dropped $14 \%$ across species, but we did not detect a reduction in overall $\mathrm{N}$ uptake, nor did tree species differ in this response. In the long-term acidification experiment, we found that soluble soil $\mathrm{Al}$ was mostly in the free $\mathrm{Al}^{3+}$ form, and the concentration of $\mathrm{Al}^{3+}$ was $\sim 65 \mu \mathrm{M}$ higher $(250 \%)$ in the mineral soil of the acidified watershed vs. an untreated watershed. Thus, increased levels of soil $\mathrm{Al}^{3+}$ under acidic deposition cause a reduction in uptake of $\mathrm{NO}_{3}{ }^{-}$by mature trees. When our ${ }^{15} \mathrm{~N}$ uptake results were applied to the watershed acidification experiment, they suggest that increased $\mathrm{Al}^{3+}$ exposure could reduce tree uptake of $\mathrm{NO}_{3}{ }^{-}$by $7.73 \mathrm{~kg} \mathrm{~N} \mathrm{ha}^{-1}$ year ${ }^{-1}$, and thus increase watershed $\mathrm{NO}_{3}{ }^{-}$discharge.

\subsection{Introduction}

The eastern United States has a history of elevated acid deposition. Emissions of $\mathrm{SO}_{2}$ and $\mathrm{NO}_{\mathrm{x}}$ from the combustion of fossil fuels in power plants in the Ohio River Basin and automobiles throughout the region have caused acidic deposition and elevated inputs of nitrogen $(\mathrm{N})$ and 
sulfur (S) during the late-20 $0^{\text {th }}$ and early-21 $1^{\text {st }}$ centuries (Driscoll et al. 2001; Galloway et al. 2004). The increased deposition of these materials onto downwind ecosystems can increase soil acidity, especially in poorly buffered soils, and lead to a variety of adverse effects (Lovett et al. 2009). These effects include loss of base cations (i.e. $\mathrm{Ca}, \mathrm{Mg}$, etc.), altered plant mineral nutrition, reduced root growth, and reduced forest productivity. Through time, elevated supply of $\mathrm{N}$ could also exceed forest $\mathrm{N}$ demand and cause $\mathrm{N}$ saturation (Aber et al. 1998). Thus, acid deposition has the potential to significantly impact the biogeochemistry of temperate forest ecosystems through soil acidification and $\mathrm{N}$ saturation.

An increase in soil acidity typically causes higher solubility of monomeric aluminum $\left(\mathrm{Al}^{3+}\right)(\mathrm{de}$ Vries et al. 2003). We define monomeric aluminum as $\mathrm{Al}^{3+}$, but other studies sometimes include different inorganic complexes in surface soils, such as various oxides of Al. Some discrepancy in plant responses to Al between studies could be caused, in part, by measurements of different forms of aluminum. We focused on $\mathrm{Al}^{3+}$ because of its increase in concentration at low $\mathrm{pH}$ and severe impact on plant roots. Root growth is severely reduced when exposed to $\mathrm{Al}^{3+}$ in solution (Delhaize and Ryan 1995; Poschenrieder et al. 2009), and while this alone can inhibit plant development, $\mathrm{Al}^{3+}$ also has a number of secondary effects on plant roots, including reduced water and nutrient uptake (Kochian 1995). The effects of $\mathrm{Al}^{3+}$ on plants have been studied extensively in the lab, and particularly on herbaceous plants and tree seedlings. However, its impact on plant growth in field conditions can be much more variable than in the lab. Al has relatively complex dissolution reactions in the soil that are dependent on the soil composition. Buffering by base cation release (i.e., calcium) (Monterroso et al. 1999; de Vries et al. 2003) and the formation of Al complexes with organic acids (Mulder and Stein 1994; Brumme et al. 2009) 
may lead to varying levels of free $\mathrm{Al}^{3+}$ species, and diverse effects, across a landscape (de Vries et al. 2003; Li and Johnson 2016). For example, Rosenberg and Butcher (2010) found no correlation between foliar and $\mathrm{BaCl}_{2}$-extractable soil $\mathrm{Al}$ concentration for red spruce in acid forest soils. In addition, de Wit et al. (2010) found that 7 years of $\mathrm{AlCl}_{3}$ addition to a Norway spruce forest did not impede root growth as seen in lab studies with seedlings of other tree species (e.g., Lux and Cumming, 1999), but the additions did reduce foliar magnesium (Mg) concentration. So, while soluble $\mathrm{Al}^{3+}$ in soil may not affect the growth of mature trees in the field to the degree suggested by laboratory studies, other aspects of their function may be altered, such as mineral nutrition.

Because of these potential negative effects, many plants reduce their exposure to $\mathrm{Al}^{3+}$ by altering the $\mathrm{Al}$ species present in the rhizosphere. When soil $\mathrm{Al}^{3+}$ increases, plant roots exude organic acids, such as citrate and malate, which chelate free $\mathrm{Al}^{3+}$ and reduce negative growth and nutritional effects (Delhaize and Ryan 1995; Kochian 1995). Thus, while bulk soil Al ${ }^{3+}$ may increase under acid deposition, its effect would be lower in the rhizosphere of Al-tolerant plants that exude chelating organic acids. This further complicates the potential biogeochemical effect of acid deposition-induced $\mathrm{Al}^{3+}$ solubility, and so it is necessary to measure the chelation of $\mathrm{Al}^{3+}$ in rhizosphere and bulk soil to adequately assess its impact on stand-scale growth and nutrient cycling.

When soluble $\mathrm{Al}^{3+}$ increases in the soil, several negative effects on plants could translate to changes in $\mathrm{N}$ demand and thus an impact on the $\mathrm{N}$ biogeochemistry of forest catchments. Should 
soil $\mathrm{Al}^{3+}$ rise to a level that reduces plant growth, overall $\mathrm{N}$ uptake by vegetation would be reduced, leading to elevated stream water $\mathrm{N}$ export. Even in the absence of a reduction in growth, the presence of soluble $\mathrm{Al}^{3+}$ can impede other aspects of tree nutrition that may alter $\mathrm{N}$ demand (de Wit et al. 2010). In particular, $\mathrm{Al}^{3+}$ exposure can reduce $\mathrm{NO}_{3}{ }^{-}$uptake by plants (Jarvis and Hatch 1986; Durieux et al. 1993; Calba and Jaillard 1997; Watanabe et al. 1998; Jerzykiewicz 2001; Pal'ove-Balang and Mistrík 2007; Zhou et al. 2016). While the exact mechanism is not established, soluble soil $\mathrm{Al}^{3+}$ can interfere with cell membrane $\mathrm{H}^{+}$-ATPase activity, reducing the cell's capacity to pump out $\mathrm{H}^{+}$(Zhou et al. 2016). This would strongly reduce the cell's ability to transport $\mathrm{NO}_{3}{ }^{-}$across the cell membrane, since $\mathrm{NO}_{3}{ }^{-}$cotransporters require $2 \mathrm{H}^{+}$per $\mathrm{NO}_{3}{ }^{-}$moved (Britto and Kronzucker 2005). Thus, the result could be a shift in relative uptake of mineral $\mathrm{N}$ forms, toward greater uptake of $\mathrm{NH}_{4}{ }^{+}$and reduced uptake of $\mathrm{NO}_{3}{ }^{-}$ (Cumming 1990). Since $\mathrm{NO}_{3}{ }^{-}$is highly mobile in soils, any reduction in the uptake of $\mathrm{NO}_{3}^{-}$ induced by higher levels of $\mathrm{Al}^{3+}$ has the potential to increase stream water $\mathrm{NO}_{3}{ }^{-}$export.

Increased $\mathrm{N}$ supply by acid deposition could cause elevated $\mathrm{NO}_{3}{ }^{-}$in stream water due to $\mathrm{N}$ saturation, and an $\mathrm{Al}^{3+}$-mediated decrease in stand $\mathrm{NO}_{3}{ }^{-}$demand would compound this effect. In a long-term, whole-watershed fertilization/acidification experiment at the Fernow Experimental Forest, $\mathrm{N}$ added as $\left(\mathrm{NH}_{4}\right)_{2} \mathrm{SO}_{4}$ has caused a persistent reduction in the $\mathrm{pH}$, and increase in the stream water $\mathrm{NO}_{3}{ }^{-}$concentration and discharge (Fig. 3-1; Adams et al. 1997; Edwards et al. 2006). While an initial increase in net nitrification was measured in the fertilized watershed relative to the reference watershed, more recent in situ and lab estimates of net nitrification rates in the upper 10-cm of mineral soil, collected at 100 points within each watershed, were unable to detect any difference in the net rate of $\mathrm{NO}_{3}{ }^{-}$production (Gilliam \& Peterjohn, unpublished data), 
despite the persistence of elevated $\mathrm{NO}_{3}{ }^{-}$concentration in stream water leaving the fertilized watershed (Fig. 3-1). This suggests that elevated $\mathrm{NO}_{3}{ }^{-}$loss from the fertilized/acidified watershed may be influenced by a decrease in $\mathrm{NO}_{3}{ }^{-}$demand, potentially due to elevated $\mathrm{Al}^{3+}$ in the soil under acidified conditions. Therefore, the main objectives of this study were to determine if tree roots are exposed to higher levels of free, unchelated $\mathrm{Al}^{3+}$ under experimental soil acidification, if this exposure could change the relative uptake of different forms of mineral $\mathrm{N}$ by important tree species in situ, and to provide an initial assessment of the potential impact that any such change might have on stream water $\mathrm{NO}_{3}{ }^{-}$export from a forested watershed. We hypothesized that (1) an increase in tree root exposure to soluble $\mathrm{Al}^{3+}$ would shift the relative uptake of mineral $\mathrm{N}$ away from $\mathrm{NO}_{3}{ }^{-}$and towards $\mathrm{NH}_{4}{ }^{+}$due to the hindrance of $\mathrm{NO}_{3}{ }^{-}$uptake pathways, (2) that species would vary in their sensitivity, with species that are more tolerant of acidic soils, such as Acer rubrum and Quercus rubra, being less affected by increased levels of soluble $\mathrm{Al}^{3+}$, and (3) that soil acidification causes levels of soluble $\mathrm{Al}^{3+}$ that have the potential to elevate stream water $\mathrm{NO}_{3}{ }^{-}$discharge from a watershed if $\mathrm{N}$ uptake by most of the species present were Al sensitive.

\subsection{Methods}

Site description

This research was conducted in the Fernow Experimental Forest (FEF) in Tucker County, WV. This site is a mixed hardwood forest, and the soil is primarily a Calvin channery silt loam (loamy-skeletal, mixed, mesic Typic Dystrochrept). Elevation ranges from 762 to $854 \mathrm{~m}$, and average annual precipitation totals $\sim 145 \mathrm{~cm}$ (Kochenderfer 2006). To test if $\mathrm{Al}^{3+}$ affects the 
relative uptake of $\mathrm{NO}_{3}{ }^{-}$versus $\mathrm{NH}_{4}{ }^{+}$, we used an area of the $\mathrm{FEF}$ with no assigned long-term treatment, to avoid affecting the $\delta^{15} \mathrm{~N}$ of the experimental areas. The area was last used in the 1980s, when 0.2 ha plots were harvested to varying levels of basal area. However, we selected mature canopy trees that were similarly-sized to those in the nearby acidified watershed $(<1 \mathrm{~km}$ away), and we avoided areas with signs of harvest.

To assess the potential effects of acidification on plant available Al in the soil, we used the longterm watershed acidification experiment at the FEF. This is a paired watershed experiment consisting of two adjacent watersheds - an acidified 34-ha watershed (WS 3, 1883 tree stems ha ${ }^{1}$ ), and a similarly aged, 24-ha reference watershed (WS 7, 1473 tree stems ha ${ }^{-1}$ ) (Kochenderfer 2006). The forest on the acidified watershed is currently dominated by Prunus serotina (52\% of the total basal area), Acer rubrum (10.9\%), Betula lenta (7.2\%), and Liriodendron tulipifera (6.4\%). In 1969-70, the watershed was clearcut, and then allowed to naturally regrow thereafter. To experimentally acidify the soils in WS $3,35 \mathrm{~kg} \mathrm{~N} \mathrm{ha}^{-1} \mathrm{yr}^{-1}$ of $\left(\mathrm{NH}_{4}\right)_{2} \mathrm{SO}_{4}$ have been aerially applied in three doses per year since 1989. The reference watershed (WS 7) is currently dominated by P. serotina (29.4\% of the total basal area), B. lenta (19.1\%), L. tulipifera (17.9\%), A. saccharum (11.3\%), A. rubrum (6\%), and Quercus rubra (4\%). This watershed was clearcut between 1963-64 and 1966-67 (lower half, then upper half) (Patric and Reinhart 1971).. The reference watershed has never received additions of $\left(\mathrm{NH}_{4}\right)_{2} \mathrm{SO}_{4}$. In 2011, after 21 years of treatment, the $\mathrm{pH}$ of the top $10 \mathrm{~cm}$ of mineral soil was significantly lower in the acidified watershed than in the reference watershed (pH 4.2 vs. 4.6), and the extractable soil $\mathrm{Al}$ (extracted with $1 \mathrm{~N}$ ammonium acetate) was significantly higher in the acidified watershed than in the reference watershed $\left(0.45 \pm 0.03\right.$ vs. $0.32 \pm 0.01 \mathrm{meq} 100 \mathrm{~g}^{-1}$; Peterjohn, unpublished data). 
Relative uptake of $\mathrm{NO}_{3}{ }^{-}$and $\mathrm{NH}_{4}^{+}$

In early July of 2014, we used an in situ ${ }^{15} \mathrm{~N}$-labelling method to determine the relative uptake of $\mathrm{NO}_{3}{ }^{-}$and $\mathrm{NH}_{4}{ }^{+}$by mature overstory trees (McKane et al. 2002; Andresen and Michelsen 2005). $\mathrm{NO}_{3}{ }^{-}$and $\mathrm{NH}_{4}{ }^{+}$pools under canopy trees were labeled with sub-fertilization amounts of either ${ }^{15} \mathrm{NH}_{4} \mathrm{Cl}$ or $\mathrm{K}^{15} \mathrm{NO}_{3}$. Five canopy trees of six important species found in WS 3 and WS 7 (Acer saccharum, A. rubrum, Betula lenta, Liriodendron tulipifera, Prunus serotina, and Quercus rubra) were selected from an area adjacent to the experimental watersheds in the FEF to avoid labeling the natural ${ }^{15} \mathrm{~N}$ pool in the soils of the long-term experimental areas. Under each tree's canopy, and within $4 \mathrm{~m}$ of the stem, four $625-\mathrm{cm}^{2}$ plots were used for the injection of labeled $\mathrm{N}$ solutions. One of four solutions were applied to each plot: (1) ${ }^{15} \mathrm{NH}_{4} \mathrm{Cl}$; (2) ${ }^{15} \mathrm{NH}_{4} \mathrm{Cl}+\mathrm{Al}^{3+}$; (3) $\mathrm{K}^{15} \mathrm{NO}_{3}$; and (4) $\mathrm{K}^{15} \mathrm{NO}_{3}+\mathrm{Al}^{3+}$. The $\mathrm{N}$ concentrations in each treatment solution were $3.5 \mathrm{mM}$. Past measurements of lysimeter soil water $\mathrm{Al}^{3+}$ from the acidified watershed yielded concentrations from zero to nearly $600 \mu \mathrm{M}$ (Lux 1999). We used $600 \mu \mathrm{M} \mathrm{Al}{ }^{3+}$ in our treatment solutions to assess the potential of $\mathrm{Al}^{3+}$ to impact tree $\mathrm{N}$ form uptake. Since some added $\mathrm{Al}^{3+}$ would rapidly associate with exchange sites on soil particles, the resulting $\mathrm{Al}^{3+}$ concentration in solution was in the range of measured lysimeter values, up to $600 \mu \mathrm{M}$. $\mathrm{Al}^{3+}$ was added as $\mathrm{Al}_{2}\left(\mathrm{SO}_{4}\right)_{3}$, and all solutions were acidified to $\mathrm{pH} 4.0$ - 4.5 using $\mathrm{HCl}$, to best match the soil $\mathrm{pH}$. Each plot consisted of a 100-hole grid frame (10x10 hole commercial pegboard, $2.54 \mathrm{~cm}$ between holes) laid on the ground to guide the injection of labeled $\mathrm{N}$ solutions. At each hole, 1 $\mathrm{mL}$ of $\mathrm{N}$ solution was injected at a depth of $3 \mathrm{~cm}$ (approximately the top of the A horizon) using a side-port syringe needle for a total of $52.5 \mathrm{mg}{ }^{15} \mathrm{~N}$ added to each plot. 
After 3 hours, a sample of fine roots $(<2 \mathrm{~mm}$ diameter $)$ of the nearby canopy tree were removed from a depth of $\sim 3 \mathrm{~cm}$. In addition to the ${ }^{15} \mathrm{~N}$-labeled plots, we collected roots from an unlabeled area around each tree for measurement of $\operatorname{root}^{15} \mathrm{~N}$ natural abundance. To maximize our confidence that the roots were from the intended tree, the roots were traced as far as possible towards the canopy tree. In addition, we compared the morphology of the collected roots to the fine roots of nearby seedlings of the same species. Four of the species had distinct root characteristics; however, the roots of the two Acer spp. were very similar. Thus, we selected $A$. saccharum trees that had no nearby $A$. rubrum trees within $\sim 15 \mathrm{~m}$, and vice versa. We placed all collected roots on ice and transported them to the lab, where they were immediately placed in $1 \mathrm{M} \mathrm{CaSO}_{4}$ for 1 min to remove unassimilated nutrients from the Donnan free space (Thornton et al. 2007). This was done to isolate the signal to $\mathrm{N}$ that had been transported across a cell membrane, and remove $\mathrm{N}$ that was passively present in the root apoplast. This may be a low amount of $\mathrm{N}$, but even a small amount could greatly influence the results when working with highly $\delta^{15} \mathrm{~N}$-enriched solutions. Root samples were then dried at $65^{\circ} \mathrm{C}$ for 48 hours, and then ground in a dental amalgamator (Henry Schein, Inc., Melville, NY). From each plot, powdered root samples ( $\sim 5 \mathrm{mg}$ each) were wrapped in tin capsules and analyzed for tissue $\delta^{15} \mathrm{~N}$ and $\mathrm{N}$ content $(\% \mathrm{~N})$ by the Central Appalachian Stable Isotope Facility at the Appalachian Laboratory of the University of Maryland (Frostburg, MD, USA).

Since the $\delta$-values of the labeled samples were highly enriched, we converted $\delta^{15} \mathrm{~N}$ values to $R_{\text {sample, the ratio of }}{ }^{15} \mathrm{~N}$ to ${ }^{14} \mathrm{~N}$ in the root sample, and calculated the value of $F$, the fraction of the heavy isotope in the sample (Fry 2006): 


$$
\begin{gathered}
R_{\text {sample }}=\left(\left(\frac{\delta^{15} N}{1000}\right) * R_{\text {std }}\right)+R_{\text {std }} \\
F=\frac{R_{\text {sample }}}{1+R_{\text {sample }}}
\end{gathered}
$$

where $R_{\text {std }}={ }^{15} \mathrm{~N} /{ }^{14} \mathrm{~N}$ ratio in atmospheric $\mathrm{N}_{2}(0.0036764)$. We then used the tissue $\mathrm{N}$ content, and $F$ values to determine the $\mu \mathrm{mol}{ }^{15} \mathrm{~N} \mathrm{~g}^{-1}$ in root tissue. Finally, we estimated the rate of ${ }^{15} \mathrm{~N}$ taken up by roots from the labeled $\mathrm{N}$ pools by dividing the ${ }^{15} \mathrm{~N}$ excess $\left({ }^{15} \mathrm{~N}\right.$ content of labeled unlabeled roots from the same tree) by the exposure time $(3 \mathrm{hrs})$. The total uptake rate of inorganic $\mathrm{N}$ from the labeled pools was the sum of our estimate of $\mathrm{NO}_{3}{ }^{-}$and $\mathrm{NH}_{4}{ }^{+}$uptake rates.

\section{Soil Al determination}

To determine the effect of whole-watershed acidification on both chelated and free monomeric soluble soil Al, we measured aqueous Al in organic and mineral soils from the two watersheds in the whole-watershed acidification study. We collected organic and mineral soil (top $15 \mathrm{~cm}$ ) from 10 plots in each watershed, combining 4 separate subsamples collected within each $\sim 10$-m radius plot into two composite samples - one for the organic and one for the mineral soil. In the lab, the mineral soils were further separated into mineral bulk soil and mineral rhizosphere soil. Any roots in the mineral soil were gently shaken to remove excess soil, and any soil remaining attached to the root was considered mineral rhizosphere soil. Due to the high density of roots in the organic horizon, this fraction was considered all rhizosphere soil. We sieved all soils through a 2-mm mesh and stored them at $4{ }^{\circ} \mathrm{C}$. Soil moisture content was measured on a subsample from each soil by mass loss after drying for $48 \mathrm{hr}$ in a $65^{\circ} \mathrm{C}$ oven. To measure total (chelated + monomeric) aqueous Al in soil solution, we used undried, fresh, sieved soil samples, combining 
$10 \mathrm{~mL}$ of distilled $\mathrm{H}_{2} \mathrm{O}$ with $10 \mathrm{~g}$ of mineral soil, and $20 \mathrm{~mL}$ of $\mathrm{H}_{2} \mathrm{O}$ with $10 \mathrm{~g}$ of organic soil. The goal of this procedure was to collect Al that is currently present in soil water close to the soil surface (top $15 \mathrm{~cm})$. This region of soil has high fine root density $\left(\sim 57 \mathrm{~g} \mathrm{~m}^{-2}\right.$ in the O-horizon and $\sim 230 \mathrm{~g} \mathrm{~m}^{-2}$ in the top $15 \mathrm{~cm}$ of mineral soil in the acidified watershed; Carrara, unpublished data). Our water addition diluted the existing soil water $\sim 3: 1$ and allowed us to collect nowdiluted soil solution after centrifugation. We chose to measure only the $\mathrm{Al}$ in soil water rather than using an ionic extractant to best estimate the $\mathrm{Al}$ that is delivered to the root surface via the soil solution. Thus, the $\mathrm{Al}$ values that we present are concentrations $(\mu \mathrm{M})$ in aqueous soil solution after accounting for the dilution factor using the initial soil moisture content, which is intended to be similar to what would be measured in lysimeters (Lux 1999; Edwards et al. 2002). All soils were shaken for $30 \mathrm{~min}$ and centrifuged for $5 \mathrm{~min}$ at $4400 \times \mathrm{g}$, and then the supernatant passed through a $0.45 \mu \mathrm{m}$ filter. To separate free monomeric $\mathrm{Al}^{3+}$ from chelated $\mathrm{Al}$ in solution, we passed each sample through a Cleanert SCX cation exchange column (Bonna-Agela Technologies, Inc., Wilmington, DE) to remove $\mathrm{Al}^{3+}$ from solution. The concentration of $\mathrm{Al}$ in the filtered and deionized (after the exchange column) solutions were then analyzed using a Varian SpectrAA 220FS graphite tube atomic absorption spectrometer (Varian, Inc., Palo Alto, $\mathrm{CA})$. The amount of chelated $\mathrm{Al}$ was subtracted from the total water-soluble $\mathrm{Al}$ to obtain the monomeric $\mathrm{Al}^{3+}$ content of each extract. Using soil moisture measurements for each sample, we adjusted the diluted $\mathrm{Al}$ values to the concentrations of the original soil water in each sample.

\section{Statistical analyses}

We used a complete 3-way ANOVA and a Tukey's HSD post-hoc analysis $(\alpha=0.05)$ to test for differences in soil Al between watersheds, soil fractions (organic, mineral bulk, mineral 
rhizosphere), forms of $\mathrm{Al}$ (chelated vs. unchelated), and to test all interactions between the three factors. We focused on the differences in unchelated $\mathrm{Al}^{3+}$ between watersheds in the mineral rhizosphere and organic horizon, since these soil fractions should best characterize the exposure of tree roots to potentially damaging $\mathrm{Al}^{3+}$.

To determine if $\mathrm{Al}^{3+}$ addition affected total uptake of $\mathrm{N}$ from the ${ }^{15} \mathrm{~N}$-labeled pool $\left({ }^{15} \mathrm{NH}_{4}\right.$ uptake $+{ }^{15} \mathrm{NO}_{3}$ uptake), we used a 2-way ANOVA with ${ }^{15} \mathrm{~N}$ uptake as the response variable and species and $\mathrm{Al}^{3+}$ addition as factors. The residuals for the rates of $\mathrm{N}$ uptake from the labeled pool were non-normal, so we natural log-transformed these data to fulfill the normality assumption of ANOVA. Thus, the reported rates of uptake of $\mathrm{N}$ from the ${ }^{15} \mathrm{~N}$ labeled pools are backtransformed means ( $\pm \mathrm{SE}$ ). To test for an effect of $\mathrm{Al}^{3+}$ on $\mathrm{NO}_{3}{ }^{-}$uptake, we used the $\mathrm{NH}_{4}{ }^{+}$and $\mathrm{NO}_{3}{ }^{-}$uptake rates from the labeled pools for each tree to calculate the total ${ }^{15} \mathrm{~N}$ uptake from the labeled pools, as well as the percentage taken up as $\mathrm{NO}_{3}{ }^{-}$, both in the presence and absence of added $\mathrm{Al}^{3+}$. We then used a 2-way ANOVA with a Tukey's HSD post-hoc analysis $(\alpha=0.05)$ to determine the effects of $\mathrm{Al}^{3+}$ and species on the percentage of ${ }^{15} \mathrm{~N}$ uptake that was $\mathrm{NO}_{3}{ }^{-}$, and to test if the effect of $\mathrm{Al}^{3+}$ depended on species. To determine if any species took up significantly more $\mathrm{NO}_{3}{ }^{-}$than $\mathrm{NH}_{4}{ }^{+}$without added $\mathrm{Al}^{3+}$, or significantly less $\mathrm{NO}_{3}{ }^{-}$than $\mathrm{NH}_{4}{ }^{+}$with added $\mathrm{Al}^{3+}$, we performed one-tailed t-tests to determine if the contribution of $\mathrm{NO}_{3}{ }^{-}$to total uptake of $\mathrm{N}$ from the labeled pool was greater (no added $\mathrm{Al}^{3+}$ ) or less $\left(\operatorname{added~} \mathrm{Al}^{3+}\right.$ ) than $50 \%$. 


\subsection{Results}

Relative uptake of $\mathrm{NO}_{3}^{-}$and $\mathrm{NH}_{4}^{+}$

Across tree species, the total $\mathrm{N}$ uptake rate from the labeled pool $\left({ }^{15} \mathrm{NH}_{4}{ }^{+}+{ }^{15} \mathrm{NO}_{3}{ }^{-}\right)$was 0.120 $\mu \mathrm{mol}{ }^{15} \mathrm{~N} \mathrm{~g}^{-1} \mathrm{hr}^{-1}$, which is similar to rates measured in prior studies from the ${ }^{15} \mathrm{~N}$ pool (McKane et al. 1990). There was no significant effect of species or $\mathrm{Al}$ treatment on total uptake of $\mathrm{N}$ from the labeled pool, and the effect of $\mathrm{Al}$ did not depend on species. Among all species, $59 \%$ ( \pm $5.2 \%)$ of $\mathrm{N}$ from the labeled pool was taken up as $\mathrm{NO}_{3}{ }^{-}\left(0.074 \pm 0.02 \mu \mathrm{mol}^{15} \mathrm{~N} \mathrm{~g}^{-1} \mathrm{hr}^{-1}\right)$, and $41 \%$ as $\mathrm{NH}_{4}{ }^{+}\left(0.046 \pm 0.05 \mu \mathrm{mol}{ }^{15} \mathrm{~N} \mathrm{~g}^{-1} \mathrm{hr}^{-1}\right)$, in the absence of added $\mathrm{Al}^{3+}$, and these proportions were not significantly different between species. However, under added $\mathrm{Al}^{3+}, \mathrm{NO}_{3}{ }^{-}$uptake from the labeled pool decreased to $44.6 \%$ ( $\pm 5.0 \%$ ) of total $\mathrm{N}$ uptake $\left(0.065 \pm 0.03 \mu \mathrm{mol}{ }^{15} \mathrm{~N} \mathrm{~g}^{-1} \mathrm{hr}^{-1}\right)$ $(F=4.38, P=0.047)$ (Fig. 3-2), and $\mathrm{NH}_{4}$ accounted for $55.4 \%$ of total $\mathrm{N}$ uptake from the labeled pool $\left(0.094 \pm 0.03 \mu \mathrm{mol}{ }^{15} \mathrm{~N} \mathrm{~g}^{-1} \mathrm{hr}^{-1}\right)$. While the mean percent of $\mathrm{N}$ uptake as $\mathrm{NO}_{3}^{-}$declined from $>50 \%$ for all species without added $\mathrm{Al}^{3+}$ to $<50 \%$ under added $\mathrm{Al}^{3+}$, no individual species decline was significant. For $A$. rubrum, there was a trend towards $\mathrm{NO}_{3}{ }^{-}$uptake contributing $>$ $50 \%$ to total uptake of $\mathrm{N}$ from the labeled pool $(t=2.03, P=0.056)$, but no other species' $\mathrm{NO}_{3}{ }^{-}$ uptake significantly differed from $50 \%$ of total uptake of $\mathrm{N}$, regardless of $\mathrm{Al}$ treatment.

\section{Soil Al determination}

The total soil solution $\mathrm{Al}$ (across all soil forms \& fractions) was $77 \%$ higher in the acidified watershed than the reference, an increase of $37.9 \mu \mathrm{M} \mathrm{Al}(\mathrm{SE}=7.3, F=5.19, P<0.001)$. Total Al was higher in the fertilized watershed in both the mineral bulk (245\%) and mineral rhizosphere (171\%) soil fractions, whereas there was no significant difference in total $\mathrm{Al}$ in the 
organic horizon (Table 3-1). Within each soil fraction (organic \& mineral), $<50 \%$ of the total soil solution Al was chelated in both watersheds (Table 3-1), and the percent chelated did not significantly differ between watersheds.

Monomeric soil solution $\mathrm{Al}^{3+}$ was $103 \%$ higher $(36.9 \mu \mathrm{M})$ in the acidified watershed than the reference (Tukey's $t=6.12, P<0.001$ ) and, within the different soil fractions, it was $64.1 \mu \mathrm{M}$ higher (283\%) (Tukey's $t=6.14, P<0.001)$ in mineral bulk soil and $67.5 \mu \mathrm{M}$ higher $(203 \%)$ (Tukey's $t=6.47, P<0.001$ ) in mineral rhizosphere soil in the acidified watershed compared to the reference watershed (Fig. 3-3) (Supplementary Table A-1). In the organic soil, there was no significant difference in monomeric soil solution $\mathrm{Al}^{3+}$ between the watersheds, despite a high statistical power $(>0.98)$ to detect a similar difference in this soil horizon as the bulk and rhizosphere mineral soils.

\subsection{Discussion}

In the absence of added $\mathrm{Al}^{3+}$ from the ${ }^{15} \mathrm{~N}$ label addition, we found little difference in relative uptake of $\mathrm{NO}_{3}{ }^{-}$vs. $\mathrm{NH}_{4}{ }^{+}$for six temperate tree species under field conditions, whereas many prior studies found that $\mathrm{NH}_{4}$ is the dominant mineral $\mathrm{N}$ form utilized by tree species (Buchmann et al. 1995; Gessler et al. 1998; Kronzucker et al. 1997; Lovett and Mitchell 2004; Malagoli et al. 2000; McFarlane and Yanai 2006; Min et al. 2000; Rothstein et al. 1996; Socci and Templer 2011; Templer and Dawson 2004). Our study differs from most of these in two important ways. First, the studies that tend to show the highest relative uptake of $\mathrm{NH}_{4}{ }^{+}$over $\mathrm{NO}_{3}{ }^{-}$used coniferous species, whereas we studied temperate deciduous species that have been exposed to decades of 
elevated atmospheric $\mathrm{N}$ deposition. For example, Buchmann et al. (1995) labeled the soil of a Picea abies plantation and estimated that uptake of ${ }^{15} \mathrm{NH}_{4}{ }^{+}$was between two and four times higher than ${ }^{15} \mathrm{NO}_{3}{ }^{-}$. Second, many previous studies placed live or excised roots directly into nutrient solutions containing one or both mineral $\mathrm{N}$ forms. While this is valuable when studying the physiology of $\mathrm{N}$ uptake at the root surface, the higher diffusional resistance of $\mathrm{NH}_{4}{ }^{+} \mathrm{vs} . \mathrm{NO}_{3}{ }^{-}$ in soil results in a greater delivery of $\mathrm{NO}_{3}{ }^{-}$to the root surface under natural conditions (Chapman et al. 2012). As a result, nutrient solution studies may underestimate the relative contribution of $\mathrm{NO}_{3}{ }^{-}$to tree $\mathrm{N}$ nutrition under field conditions. Similarly, the use of excised roots severs the transpiration stream, which drives mass flow to the root surface and is an important factor in plant $\mathrm{NO}_{3}{ }^{-}$uptake (Oyewole et al. 2014). Under more natural conditions, $\mathrm{NO}_{3}{ }^{-}$is more mobile than $\mathrm{NH}_{4}{ }^{+}$, and the movement of $\mathrm{NO}_{3}{ }^{-}$via diffusion to the root surface may lead to greater relative uptake of $\mathrm{NO}_{3}{ }^{-}$than can be measured using nutrient solutions (Fahey and Yavitt 2005). Indeed, the keystone species $A$. saccharum (sugar maple) may be a good example of how $\mathrm{N}$ uptake assessments under artificial conditions may be misleading. Sugar maples are typically thought to utilize $\mathrm{NH}_{4}{ }^{+}$as the primary mineral $\mathrm{N}$ source (Lovett and Mitchell 2004), a conclusion supported by excised root (Rothstein et al. 1996; Eddy et al. 2008; Socci and Templer 2011), nutrient solution depletion (McFarlane and Yanai 2006; Socci and Templer 2011), and greenhouse seedling studies (Templer and Dawson 2004). However, when we measured the relative importance of $\mathrm{NO}_{3}^{-}$uptake in situ, we found a much higher relative contribution of $\mathrm{NO}_{3}{ }^{-}$ to total uptake of $\mathrm{N}$ for mature trees than was indicated by many previous studies. Furthermore, the only other study that measured uptake of $\mathrm{NO}_{3}{ }^{-}$by mature $A$. saccharum trees under nearly in situ conditions found significant uptake of $\mathrm{NO}_{3}^{-}$, and also found that $A$. saccharum took up $\mathrm{NO}_{3}{ }^{-}$ at a higher rate than three other temperate broadleaf species (Fahey and Yavitt 2005). Therefore, 
we suggest that in situ ${ }^{15} \mathrm{~N}$-labeling techniques may provide meaningful insight into the mineral $\mathrm{N}$ uptake dynamics of mature trees under natural conditions.

Our in situ findings of a reduction in the relative amount of $\mathrm{NO}_{3}{ }^{-}$uptake under $\mathrm{Al}$ exposure in our ${ }^{15} \mathrm{~N}$ labeling experiment support our first hypothesis, and these results generally agree with prior greenhouse- and laboratory-based studies on herbaceous and woody plants. $\mathrm{NO}_{3}{ }^{-}$uptake reductions in plants exposed to Al have been found in maize (Durieux et al. 1993; Calba and Jaillard 1997), cucumber (Jerzykiewicz 2001), barley (Watanabe et al. 1998), and Lotus (Pal'ove-Balang and Mistrík 2007), as well as in the tropical tree Melaleuca cajuputi (Watanabe et al. 1998) and coniferous tree Pinus rigida (Cumming 1990). In addition, Al had a greater impact on growth when Pinus rigida seedlings were grown with primarily $\mathrm{NO}_{3}{ }^{-}$versus $\mathrm{NH}_{4}{ }^{+}$or mixed N sources (Cumming and Weinstein 1990). Thus, our in situ measurement of this pulse effect on six important tree species suggests that acidic deposition has the potential to reduce stand $\mathrm{NO}_{3}{ }^{-}$demand in a temperate deciduous forest, at least short-term, as $\mathrm{Al}^{3+}$ becomes soluble in the soil under field conditions. Should the $\mathrm{Al}^{3+}$ effect on $\mathrm{NO}_{3}{ }^{-}$uptake persist, reduced stand $\mathrm{NO}_{3}{ }^{-}$demand would be sustained and impact longer-term discharge of $\mathrm{N}$.

Our experiment of $\mathrm{Al}^{3+}$ addition to ${ }^{15} \mathrm{~N}$-labeled solutions was a pulse addition of $\mathrm{Al}^{3+}$, which contrasts somewhat with the long-term effects of whole-watershed acidification. We altered the $\mathrm{Al}^{3+}$ concentration at the interface of the organic and mineral soil ( $3 \mathrm{~cm}$ depth), but we only measured a long-term acidification effect on $\mathrm{Al}^{3+}$ concentration in the mineral soil. So, one assumption of our method was that $\mathrm{Al}^{3+}$ would similarly impact fine root uptake of $\mathrm{NO}_{3}{ }^{-}$in 
deeper mineral soil (up to $15 \mathrm{~cm}$ ) as at the interface between mineral and organic soil. Pulses of $\mathrm{Al}^{3+}$ exposure could result from rain storms that increase soil moisture and mobilize $\mathrm{Al}^{3+}$ in acidic soils, leading to greater movement of $\mathrm{Al}^{3+}$ to the root surface via mass flow. The spike of $\mathrm{Al}^{3+}$ in soil solution caused by our experimental addition was similar to what we observed in the soil of the long-term acidified watershed, so the physiological responses of the trees may also be similar. However, it is unknown if trees acclimate to long-term $\mathrm{Al}^{3+}$ exposure, thus recovering their uptake of $\mathrm{NO}_{3}{ }^{-}$under more natural conditions. Some evidence from herbaceous plants suggests that the effect of $\mathrm{Al}^{3+}$ persists. Maize plants showed no signs of short-term acclimation to $\mathrm{Al}^{3+}$ after 8 hours of exposure (Durieux et al. 1993), although they recovered rapidly once they were removed from $\mathrm{Al}^{3+}$ solutions. The uptake of $\mathrm{NO}_{3}{ }^{-}$by white clover was also affected by $\mathrm{Al}^{3+}$ over a period of 5 weeks (Jarvis and Hatch 1986). In trees, there is also evidence of long-term effects on growth and tissue Ca:Al ratios (Vanguelova et al. 2007), although the effects vary between methods and species. Phillips and Yanai (2004) added $\mathrm{AlCl}_{3}$ to $\mathrm{A}$. saccharum trees in the field for two years, and found that $\mathrm{Al}$ content in the rhizosphere was reduced relative to bulk soil, suggesting that Al leached from the rhizosphere due to increased organic acid efflux from tree roots. However, we did not find a decrease in soluble $\mathrm{Al}^{3+}$ in the rhizosphere soils of our paired watershed study, so the effects of $\mathrm{Al}^{3+}$ would not be relieved in this manner. Thus, while a reduction in the uptake of $\mathrm{NO}_{3}{ }^{-}$may lessen over time, prior evidence suggests that at least some $\mathrm{Al}^{3+}$ effect persists while it remains in soil solution.

Surprisingly, contrary to our second hypothesis, our ${ }^{15} \mathrm{~N}$ labeling results suggest that the tree species we studied did not differ in the impact of $\mathrm{Al}^{3+}$ on percent of $\mathrm{N}$ uptake as $\mathrm{NO}_{3}{ }^{-}$. This contrasts with prior evidence of variable $\mathrm{Al}^{3+}$ sensitivity between species (Kochian 1995; 
Watanabe et al. 1998), including temperate deciduous trees (Halman et al. 2015). Since we collected roots $3 \mathrm{~h}$ after treatment application, we measured their initial response to added $\mathrm{Al}^{3+}$. It is possible that some species would increase $\mathrm{Al}^{3+}$-resistance over a longer time period by, for example, increasing root efflux of organic acids to chelate rhizosphere $\mathrm{Al}^{3+}$ (Kochian 1995). Also, our treatment levels of $\mathrm{Al}^{3+}$ were relatively low to mimic the measured increase in the soil of the acidified watershed. We estimate that our levels of added $\mathrm{Al}^{3+}(\sim 50-100 \mu \mathrm{M}$ exposed to plant roots, or $2.16-4.32 \mathrm{mg} \mathrm{Al} \mathrm{m}^{-2}$ ) were approximately $2 \%$ of the treatment level of Halman et al. (2015) (182 $\mathrm{mg} \mathrm{Al} \mathrm{m}^{-2}$ year $\left.^{-1}\right)$, who also studied temperate forest trees. It is possible that the species reacted similarly because these levels were lower than the threshold for $\mathrm{Al}^{3+}$ response by sensitive species (Vanguelova et al. 2007). Thus, low levels of $\mathrm{Al}^{3+}$ in acidified soils can rapidly affect uptake of $\mathrm{NO}_{3}{ }^{-}$across dominant temperate tree species.

Measuring uptake of $\mathrm{N}$ in situ by isotopically labeling the available pool presents some significant challenges. First, the use of a labor intensive and higher-cost ${ }^{15} \mathrm{~N}$ labeling method limited our sample size to 5 trees of each species. As a result, our ability to detect differences between species was likewise limited. We conducted an iterative post hoc power analysis, following the methods of Sokal and Rohlf (1981), using an $\alpha$ of 0.05 . This revealed that our sample size led to a relatively low statistical power $(1-\beta)$ of $\sim 0.1$ to detect a similar effect of $\mathrm{Al}^{3+}$ on uptake of $\mathrm{NO}_{3}{ }^{-}$as a percent of total uptake of $\mathrm{N}$ within species as we found across species. The sample size would need to be increased to 66 or greater, depending on species, to reach a statistical power of 0.8 . Our results can still be applied to stands given the $\mathrm{Al}^{3+}$ effect across species, and further studies on the effects within species could yield interesting results. Second, assimilated $\mathrm{N}$ is moved away from the roots into the tree, and the rate at which this happens is 
difficult to estimate in situ. Given our relatively short time from ${ }^{15} \mathrm{~N}$ addition to root excavation $(3 \mathrm{~h})$, our estimated uptake rates should be close approximations of the actual uptake of ${ }^{15} \mathrm{~N}$ from the labeled pools. The movement of $\mathrm{N}$ from the roots into the tree could affect the measured proportion of uptake as $\mathrm{NO}_{3}{ }^{-}$versus $\mathrm{NH}_{4}{ }^{+}$if they have different residence times in the root tissue. The reduction of $\mathrm{NO}_{3}{ }^{-}$occurs mostly in leaves in temperate deciduous tree species (Tang et al. 2012), potentially minimizing this effect. However, differential movement of the two $\mathrm{N}$ forms out of root tissue could result in an underestimation of the relative contribution of $\mathrm{NH}_{4}{ }^{+}$to overall $\mathrm{N}$ uptake if reduced $\mathrm{NO}_{3}{ }^{-}$is stored in roots. Finally, it is also difficult to measure total $\mathrm{N}$ uptake using an in situ labeling method in undisturbed soil. To do so, an accurate measurement of the ${ }^{15} \mathrm{~N}$ atom percent in the soil at the root surface after the label is added would be necessary. As such, we have presented our results as uptake of ${ }^{15} \mathrm{~N}$ from the labeled pool, rather than total uptake of $\mathrm{N}$, and focused on the proportions taken up as the two different mineral $\mathrm{N}$ forms. With efforts to minimize these methodological concerns, our measurements of root uptake from undisturbed soil provide important advantages that should be considered when conducting research in situ.

Not surprisingly, in the whole-watershed acidification experiment, we found that soluble soil $\mathrm{Al}^{3+}$ increased under long-term treatment (since 1989), indicating that soil acidification causes an increase in monomeric $\mathrm{Al}^{3+}$ in the upper mineral soil. We found comparable levels of soluble soil $\mathrm{Al}^{3+}$ that we measured (87-101 $\mu \mathrm{M}$ in bulk soil, Table 3-1) to prior measurements in lysimetercollected soil water in the same watershed $(107 \mu \mathrm{M}$; Lux, 1999), which suggests that our aqueous extraction method yielded accurate measurements of actual soil solution $\mathrm{Al}^{3+}$. Monomeric $\mathrm{Al}^{3+}$ was elevated in both the bulk and rhizosphere mineral soils, so $\mathrm{Al}^{3+}$ directly 
impacts tree roots in the mineral soil. There was no significant difference in organic soil $\mathrm{Al}^{3+}$ between watersheds, yet the measured levels may still be high enough $(30-50 \mu \mathrm{M})$ to affect root uptake of $\mathrm{NO}_{3}{ }^{-}$in this soil horizon. It is possible that long-term acidic deposition in the region caused these levels of $\mathrm{Al}^{3+}$ even in the reference watershed, as was seen by Lux (1999). Also, additional soluble soil $\mathrm{Al}^{3+}$ under experimental acidification of the treated watershed could readily associate with exchange sites on organic material, reducing the treatment's effect on $\mathrm{Al}^{3+}$ in soil solution. Since the organic horizon is an area of high root density, the fact that $\mathrm{Al}^{3+}$ did not increase in this horizon under experimental acidification could relieve some of the effect of $\mathrm{Al}^{3+}$ on root uptake of $\mathrm{NO}_{3}{ }^{-}$at the stand level. However, there were actually more roots $\mathrm{m}^{-2}$ in the top $15 \mathrm{~cm}$ of mineral soil than in the organic horizon in these watersheds $\left(\sim 57 \mathrm{~g} \mathrm{~m}^{-2}\right.$ in the Ohorizon versus $\sim 230 \mathrm{~g} \mathrm{~m}^{-2}$ in the mineral soil in the acidified watershed; Carrara, unpublished data). As a result, our results still support the hypothesis that acidification increases $\mathrm{Al}^{3+}$ to levels that diminish the relative uptake of $\mathrm{NO}_{3}^{-}$, potentially impacting watershed $\mathrm{NO}_{3}{ }^{-}$dynamics. Furthermore, we did not detect a decrease in overall $\mathrm{N}$ uptake from the labeled pool under $\mathrm{Al}^{3+}$ treatment; instead, uptake remained stable, but the proportion of $\mathrm{N}$ taken up as $\mathrm{NO}_{3}{ }^{-}$decreased. This emphasizes that soluble soil $\mathrm{Al}^{3+}$ can impact the pool of mineral $\mathrm{N}$ used by overstory trees under long-term acidic deposition, and thus potentially increase $\mathrm{NO}_{3}{ }^{-}$discharge from the watershed.

As an initial assessment of the potential impact of $\mathrm{Al}$ on the export of $\mathrm{NO}_{3}{ }^{-}$in stream water at the scale of a small watershed, we applied the results of our ${ }^{15} \mathrm{~N}$-labeling experiment to estimates of total $\mathrm{N}$ uptake by the trees growing in the acidified watershed at the FEF (WS 3). Under wholewatershed fertilization and acidification, the discharge of $\mathrm{NO}_{3}-\mathrm{N}$ increased from $4.17 \mathrm{~kg} \mathrm{~N} \mathrm{ha}^{-1}$ 
year ${ }^{-1}$ pre-fertilization (1982-1989) to $13.82 \mathrm{~kg} \mathrm{~N} \mathrm{ha}^{-1}$ year $^{-1}$ post-fertilization (1990-2009), an increase of $9.65 \mathrm{~kg} \mathrm{~N} \mathrm{ha}^{-1}$ year $^{-1}$ (Fig. 3-1). However, at the same time there was no detectable difference in mineral soil net nitrification rate between the two watersheds (Gilliam \& Peterjohn, unpublished data). So, reduced stand $\mathrm{NO}_{3}{ }^{-}$demand due to soil $\mathrm{Al}$ may contribute to the higher $\mathrm{NO}_{3}{ }^{-}$discharge in stream water in the acidified watershed. We estimated tree uptake of $\mathrm{NO}_{3}{ }^{-}$in the acidified watershed by multiplying an estimate of total $\mathrm{N}$ uptake ( $\mathrm{N}$ return in leaf litter + aboveground woody $\mathrm{N}$ storage) $\left(50.95 \mathrm{~kg} \mathrm{ha}^{-1} \mathrm{year}^{-1}\right)$ by our ${ }^{15} \mathrm{~N}$-label measurement of percent of uptake as $\mathrm{NO}_{3}{ }^{-}$both without and with added $\mathrm{Al}^{3+}\left(59 \%\right.$ and $44.6 \%$ of total $\mathrm{N}$ uptake as $\mathrm{NO}_{3}{ }^{-}$, respectively). Aboveground woody $\mathrm{N}$ storage was calculated by multiplying bole wood $\mathrm{N}$ content in the outer $1 \mathrm{~cm}$ by the annual stand woody biomass increase reported by DeWalle et al. (2006). The resulting difference between $\mathrm{NO}_{3}{ }^{-}$uptake without and with added $\mathrm{Al}^{3+}$, an estimate of unassimilated, excess soil $\mathrm{NO}_{3}{ }^{-}$available for leaching due to the impact of $\mathrm{Al}^{3+}$, is $7.73 \mathrm{~kg} \mathrm{~N}$ $\mathrm{ha}^{-1}$ year $^{-1}$. If this amount was completely discharged in stream water, the effect of increased $\mathrm{Al}^{3+}$ would account for up to $76 \%$ of the $9.65 \mathrm{~kg} \mathrm{~N} \mathrm{ha}^{-1}$ year $^{-1}$ increase in stream water $\mathrm{NO}_{3}{ }^{-}$due to whole-watershed acidification. Perhaps more realistically, if $\sim 70 \%$ of this unassimilated $\mathrm{NO}_{3}{ }^{-}$ were retained in the watershed, as measured by Adams et al. (2006), then elevated $\mathrm{Al}^{3+}$ would still cause $23 \%$ of the increase in stream water $\mathrm{NO}_{3}{ }^{-}$. While this initial estimate is specific to our study site, the potential magnitude of the effect of elevated soil $\mathrm{Al}^{3+}$ on watershed $\mathrm{NO}_{3}{ }^{-}$ discharge is large enough to warrant more detailed assessments at a variety of locations. 


\subsection{Tables and Figures}

Table 3-1. Total soil solution $\mathrm{Al}(\mu \mathrm{M})$ (monomeric $\mathrm{Al}^{3+}+$ chelated $\mathrm{Al}$ ) in three soil fractions within the acidified and reference watersheds, and the percent of total Al that was chelated. Total Al values that do not share a like letter are significantly different (Tukey's HSD post-hoc analysis, $\alpha=0.05)$.

\begin{tabular}{lcc}
\hline \hline & $\begin{array}{c}\text { Acidified } \\
\text { Mean }(\mathrm{SE})\end{array}$ & \multicolumn{1}{c}{ Reference } \\
\hline Organic soil & $46.0^{\mathrm{bc}}(7.3)$ & $76.9^{\mathrm{ab}}(12.2)$ \\
Total Al & $38 \%(5.1)$ & $32 \%(3.1)$ \\
Percent chelated & & \\
\hline Mineral bulk soil & $103.3^{\mathrm{a}}(11.1)$ & $29.9^{\mathrm{c}}(6.3)$ \\
Total Al & $16 \%(2.8)$ & $23 \%(9.5)$ \\
Percent chelated & & \\
Mineral rhizosphere soil & & \\
Total Al & $113.2^{\mathrm{a}}(9.4)$ & $41.8^{\mathrm{bc}}(5.5)$ \\
Percent chelated & $11 \%(2.2)$ & $20 \%(4.0)$ \\
\hline
\end{tabular}




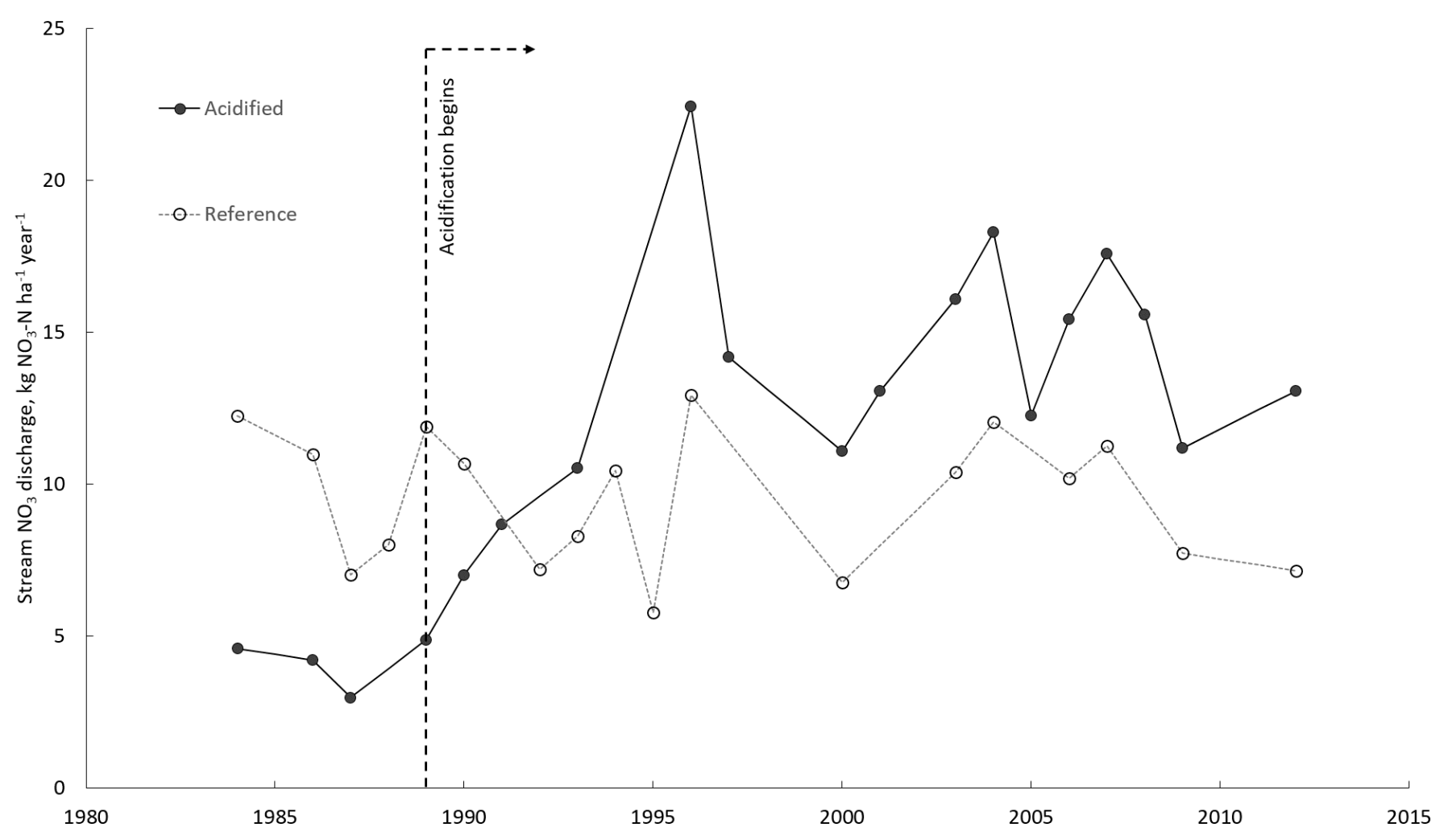

Figure 3-1. Annual stream water $\mathrm{NO}_{3}{ }^{-}$discharge from the acidified (WS3) and reference (WS7) watersheds. Vertical dashed line indicates the start of the annual addition of $35 \mathrm{~kg} \mathrm{~N} \mathrm{ha}^{-1} \mathrm{yr}^{-1}$ as $\left(\mathrm{NH}_{4}\right)_{2} \mathrm{SO}_{4}$ to the acidified watershed. Only years with values for all months were included for a given watershed. 


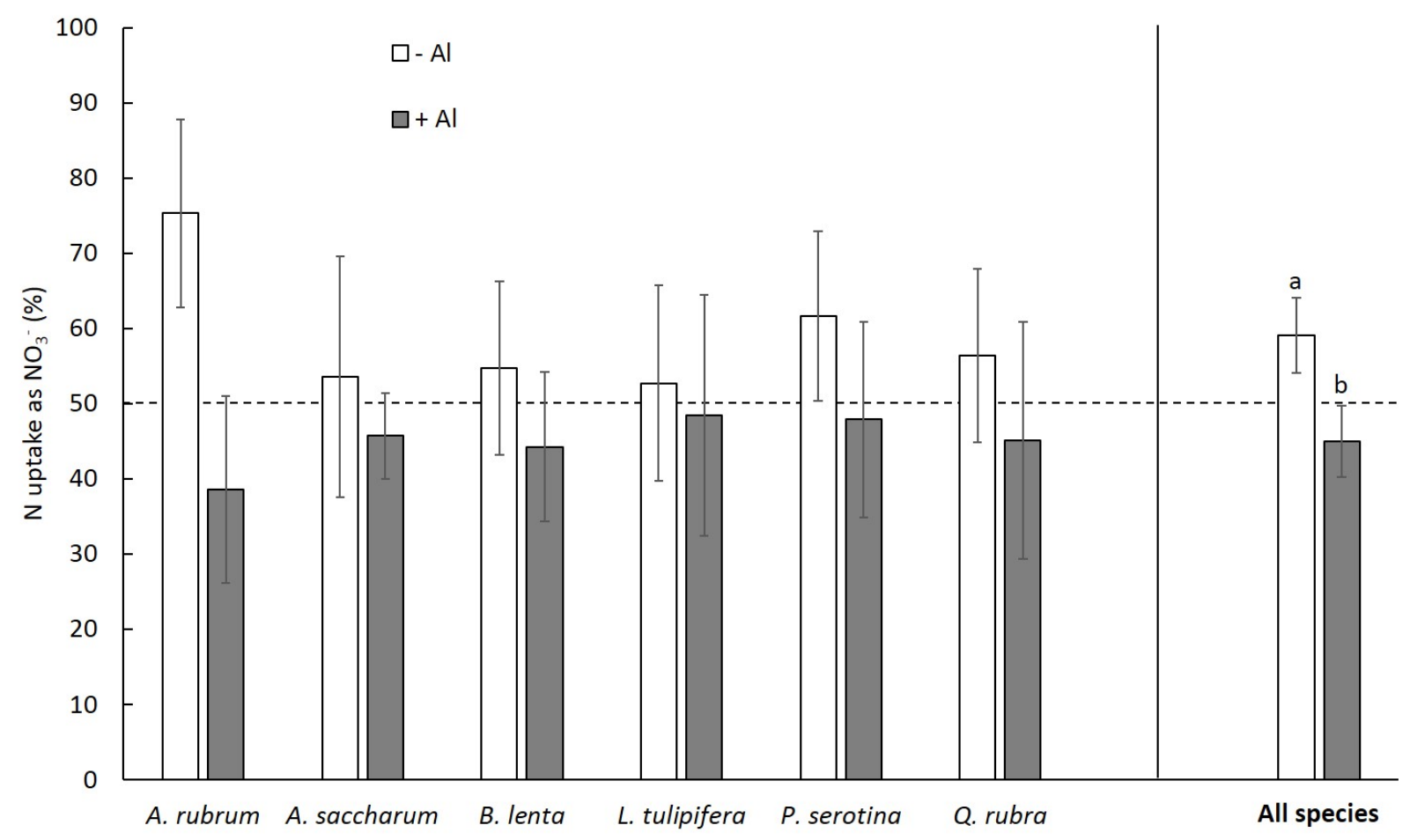

Figure 3-2. The percent of ${ }^{15} \mathrm{~N}$ taken up from the labeled pools as $\mathrm{NO}_{3}{ }^{-}$in the presence or absence of added $\mathrm{Al}^{3+}$ for the 6 temperate broadleaf tree species, and averaged across all species (far right). Bars that do not share a like letter are significantly different (Tukey's HSD post-hoc analysis, $\alpha=0.05$ ). No individual species percent ${ }^{15} \mathrm{~N}$ uptake as $\mathrm{NO}_{3}{ }^{-}$was significantly affected by $\mathrm{Al}^{3+}$ addition. Dotted line shows $50 \%$ threshold of ${ }^{15} \mathrm{~N}$ uptake as $\mathrm{NO}_{3}{ }^{-}$for visual comparison. 


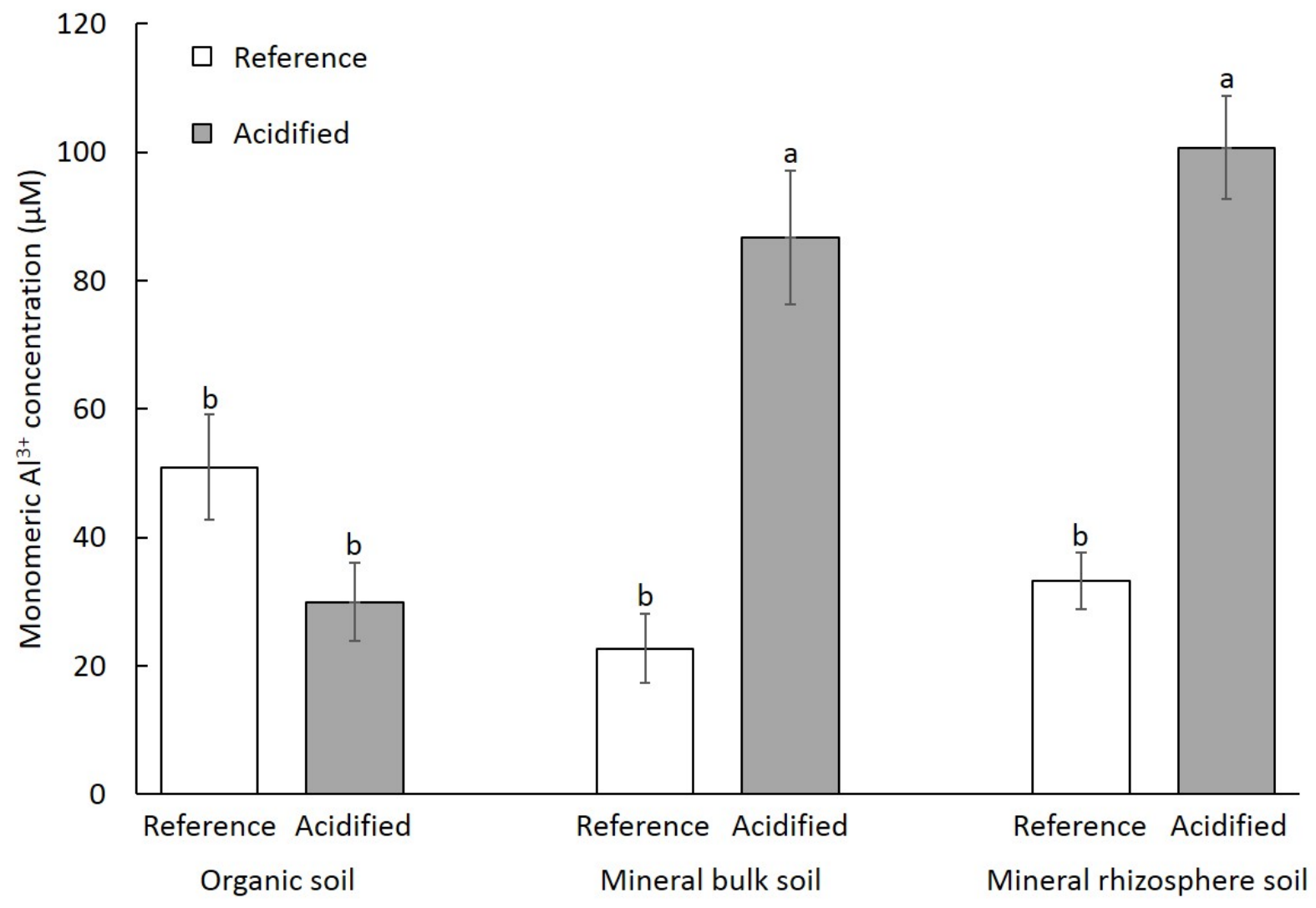

Figure 3-3. Monomeric soil solution $\mathrm{Al}^{3+}(\mu \mathrm{M})$ in three soil fractions of the acidified and reference watersheds. Bars that do not share a like letter are significantly different (Tukey's HSD post-hoc analysis, $\alpha=0.05)$. 


\subsection{References}

Aber J, McDowell W, Nadelhoffer K, Magill A, Bernston G, Kamakea M, McNulty S, Currie W, Rustad L, Fernandez I (1998) Nitrogen saturation in temperate forest ecosystems. Bioscience 48:921-934.

Adams M, Peterjohn W, Gilliam F (2006) Acidification and Nutrient Cycling. In: Adams M, DeWalle D, Hom J (eds) The Fernow Watershed Acidification Study. Springer, Dordrecht, pp 207-236

Adams MB, Angradi TR, Kochenderfer JN (1997) Stream water and soil solution responses to 5 years of nitrogen and sulfur additions at the Fernow Experimental Forest, West Virginia. For Ecol Manage 95:79-91.

Andresen L, Michelsen A (2005) Off-season uptake of nitrogen in temperate heath vegetation. Oecologia 144:585-597.

Britto DT, Kronzucker HJ (2005) Nitrogen acquisition, PEP carboxylase, and cellular pH homeostasis: new views on old paradigms. Plant, Cell Environ 28:1396-1409. doi: $10.1111 / \mathrm{j} .1365-3040.2005 .01372 . x$

Brumme R, Meesenburg H, Bredemeier M, Jacobsen C, Schonfelder E, Meiwes K, Eichhorn J (2009) Changes in soil solution chemistry, seepage, losses, and input-output budgets at three beech forests in response to atmospheric depositions. In: Brumme R, Khanna P (eds) Functioning and Management of European Beech Ecosystems. Berlin, p 499

Buchmann N, Schultz E, Gebauer G (1995) ${ }^{15} \mathrm{~N}$-ammonium and ${ }^{15} \mathrm{~N}$-nitrate uptake of a 15 -YearOld Picea abies plantation. Oecologia 102:361-370. 
Calba H, Jaillard B (1997) Effect of aluminum on ion uptake and $\mathrm{H}^{+}$release by maize. New Phytol 137:607-616.

Chapman N, Miller AJ, Lindsey K, Whalley WR (2012) Roots, water, and nutrient acquisition: Let's get physical. Trends Plant Sci 17:701-710. doi: 10.1016/j.tplants.2012.08.001

Cumming J, Weinstein L (1990) Nitrogen source effects on Al toxicity in nonmycorrhizal and mycorrhizal pitch pine (Pinus rigida) seedlings. I. Growth and nutrition. Can J Bot 68:2644-2652.

Cumming JR (1990) Nitrogen source effects on Al toxicity in nonmycorrhizal and mycorrhizal pitch pine (Pinus rigida) seedlings. II. Nitrate reduction and $\mathrm{NO}_{3}{ }^{-}$uptake. Can J Bot 68:2653-2659.

de Vries W, Reinds G., Vel E (2003) Intensive monitoring of forest ecosystems in Europe 2: Atmospheric deposition and its impacts on soil solution chemistry. For Ecol Manage 174:97-115. doi: 10.1016/S0378-1127(02)00030-0

de Wit HA, Eldhuset TD, Mulder J (2010) Dissolved Al reduces Mg uptake in Norway spruce forest: Results from a long-term field manipulation experiment in Norway. For Ecol Manage 259:2072-2082. doi: 10.1016/j.foreco.2010.02.018

Delhaize E, Ryan P (1995) Aluminum toxicity and tolerance in plants. Plant Physiol 107:315321.

DeWalle D, Kochenderfer J, Adams M, Miller G, Gilliam F, Wood F, Odenwald-Clemens S, Sharpe W (2006) Vegetation and Acidification. In: Adams M, DeWalle D, Hom J (eds) The Fernow Watershed Acidification Study. Springer, Dordrecht, pp 137-188 
Driscoll CT, Lawrence GB, Bulger AJ, Butler TJ, Cronan CS, Eagar C, Lambert KF, Likens GE, Stoddard JL, Weathers KC (2001) Acidic deposition in the northeastern United States: Sources and inputs, ecosystems effects, and management strategies. Bioscience 51:180198. doi: 10.1641/0006-3568(2001)051[0180:ADITNU]2.0.CO;2

Durieux R, Jackson W, Kamprath E, Moll R (1993) Inhibition of nitrate uptake by aluminum in maize. Plant Soil 151:97-104.

Eddy WC, Zak DR, Holmes WE, Pregitzer KS (2008) Chronic atmospheric $\mathrm{NO}_{3}{ }^{-}$deposition does not induce $\mathrm{NO}_{3}{ }^{-}$use by Acer saccharum Marsh. Ecosystems 11:469-477. doi: $10.1007 / \mathrm{s} 10021-008-9134-3$

Edwards PJ, Kochenderfer JN, Coble DW, Adams MB (2002) Soil leachate responses during 10 years of induced whole-watershed acidification. Water Air Soil Pollut 140:99-118. doi: 10.1023/A:1020181800320

Edwards PJ, Williard KWJ, Wood F, Sharpe WE (2006) Soil water and stream water chemical responses. In: Adams M, DeWalle D, Hom J (eds) The Fernow Watershed Acidification Study. Springer, Dordrecht, pp 71-136

Fahey TJ, Yavitt JB (2005) An in situ approach for measuring root-associated respiration and nitrate uptake of forest trees. Plant Soil 272:125-131. doi: 10.1007/s11104-004-4212-6

Fry B (2006) Stable Isotope Ecology, 1st edn. Springer, New York Galloway J, Dentener F, Capone D, Boyer E, Howarth R, Seitzinger S, Asner G, Cleveland C, Green P, Holland E, Karl D, Michaels A, Porter J, Townsend A, Vorosmarty C (2004) Nitrogen cycles: past, present, and future. Biogeochemistry 70:153-226. 
Gessler A, Schneider S, Sengbusch D Von, Weber P, Haneman U, Huber C, Rothe A, Kreutzer K, Rennenberg H (1998) Field and laboratory experiments on net uptake of nitrate and ammonium by the roots of spruce (Picea abies) and beech (Fagus sylvatica) trees. New Phytol 138:275-285.

Halman JM, Schaberg PG, Hawley GJ, Hansen CF, Fahey TJ (2015) Differential impacts of calcium and aluminum treatments on sugar maple and American beech growth dynamics. Can J For Res 45:52-59. doi: 10.1139/cjfr-2014-0250

Jarvis SC, Hatch DJ (1986) The effects of low concentrations of aluminum on the growth and uptake of nitrate-N by white clover. Plant Soil 95:43-55.

Jerzykiewicz J (2001) Aluminum effect on nitrate assimilation in cucumber (Cucumis sativus L.) roots. Acta Physioligiae Plant 23:213-219.

Kochenderfer JN (2006) Fernow and the Appalachian Hardwood Region. In: Adams M, DeWalle D, Hom J (eds) The Fernow Watershed Acidification Study. Springer, Dordrecht, pp 17-39

Kochian L V (1995) Cellular Mechanisms of Aluminum Toxicity and Resistance in Plants. Annu Rev Plant Physiol Plant Mol Biol 46:237-260. doi: 10.1146/annurev.pp.46.060195.001321

Kronzucker HJ, Siddiqi MY, Glass ADM (1997) Conifer root discrimination against soil nitrate and the ecology of forest succession. Nature 385:59-61.

Li W, Johnson CE (2016) Relationships among pH, aluminum solubility and aluminum complexation with organic matter in acid forest soils of the Northeastern United States. Geoderma 271:234-242. doi: 10.1016/j.geoderma.2016.02.030 
Lovett G, Mitchell M (2004) Sugar maple and nitrogen cycling in the forests of Eastern North America. Front Ecol Environ 2:81-88.

Lovett GM, Tear TH, Evers DC, Findlay SEG, Cosby BJ, Dunscomb JK, Driscoll CT, Weathers KC (2009) Effects of air pollution on ecosystems and biological diversity in the eastern United States. Ann N Y Acad Sci 1162:99-135. doi: 10.1111/j.1749-6632.2009.04153.x

Lux HB (1999) The effects of aluminum and nitrogen on mycorrhizal and non-mycorrhizal tulip poplar. MS Thesis, West Virginia University, Morgantown, WV, USA.

Lux HB, Cumming JR (1999) Effect of aluminum on the growth and nutrition of tulip-poplar seedlings. Can J For Res 29:2003-2007. doi: 10.1139/cjfr-29-12-2003

Malagoli M, Canal AD, Quaggiotti S, Pegoraro P, Bottacin A (2000) Differences in nitrate and ammonium uptake between Scots pine and European larch. Plant Soil 221:1-3.

McFarlane KJ, Yanai RD (2006) Measuring nitrogen and phosphorus uptake by intact roots of mature Acer saccharum Marsh., Pinus resinosa Ait., and Picea abies (L.) Karst. Plant Soil 279:163-172. doi: 10.1007/s11104-005-0838-2

McKane R, Grigal D, Russelle M (1990) Spatiotemporal differences in ${ }^{15} \mathrm{~N}$ uptake and the organization of an old-field plant community. Ecology 71:1126-1132.

McKane RB, Johnson LC, Shaver GR, Nadelhoffer KJ, Rastetter EB, Fry B, Giblin AE, Kielland K, Kwiatkowski BL, Laundre J a, Murray G (2002) Resource-based niches provide a basis for plant species diversity and dominance in arctic tundra. Nature 415:68-71. doi: $10.1038 / 415068 \mathrm{a}$ 
Min X, Siddiqi MY, Guy RD, Glass ADM, Kronzucker HJ (2000) A comparative kinetic analysis of nitrate and ammonium influx in two early-successional tree species of temperate and boreal forest ecosystems. Plant, Cell Environ 23:321-328. doi: 10.1046/j.13653040.2000.00546.x

Monterroso C, Alvarez E, Fernandez-Marcos M, Macias F (1999) Geochemistry of aluminium and iron in mine soils from As Pontes, Galicia (N.W. Spain). Water Air Soil Pollut 110:81102. doi: $10.1023 / \mathrm{A}: 1005055704392$

Mulder J, Stein A (1994) The solubility of aluminum in acidic forest soils: Long-term changes due to acid deposition. Geochim Cosmochim Acta 58:85-94. doi: 10.1016/00167037(94)90448-0

Oyewole OA, Inselsbacher E, Nasholm T (2014) Direct estimation of mass flow and diffusion of nitrogen compounds in solution and soil. New Phytol 201:1056-1064. doi: $10.1111 / \mathrm{nph} .12553$

Pal'ove-Balang P, Mistrík I (2007) Impact of low pH and aluminium on nitrogen uptake and metabolism in roots of Lotus japonicus. Biologia (Bratisl) 62:715-719. doi: $10.2478 / \mathrm{s} 11756-007-0133-1$

Patric J, Reinhart K (1971) Hydrologic effects of deforesting two mountain watersheds in West Virginia. Water Resour Res 7:1182-1188.

Phillips RP, Yanai RD (2004) The effect of $\mathrm{AlCl}_{3}$ additions on rhizosphere soil and fine root chemistry of sugar maple (Acer saccharum). Water, Air, Soil Pollut 159:339-356. doi: 10.1023/B:WATE.0000049187.35869.7d 
Poschenrieder C, Amenos M, Corrales I, Doncheva S, Barcelo J (2009) Root behavior in response to aluminum toxicity. In: Baluska F (ed) Plant-Environment Interactions. SpringerVerlag, Berlin, p 313

Rosenberg MB, Butcher DJ (2010) Investigation of acid deposition effects on southern Appalachian red spruce (Picea rubens) by determination of calcium, magnesium, and aluminum in foliage and surrounding soil using ICP-OES. Instrum Sci Technol 38:341-358. doi: $10.1080 / 10739149.2010 .508968$

Rothstein DE, Zak DR, Pregitzer KS, Url S, Zak R (1996) Nitrate deposition in northern hardwood forests and the nitrogen metabolism of Acer saccharum marsh. Oecologia $108: 338-344$.

Socci AM, Templer PH (2011) Temporal patterns of inorganic nitrogen uptake by mature sugar maple (Acer saccharum Marsh.) and red spruce (Picea rubens Sarg.) trees using two common approaches. Plant Ecol Divers 4:141-152. doi: 10.1080/17550874.2011.624557

Sokal RR, Rohlf FJ (1981) Biometry, 2nd edn. W. H. Freeman and Company, New York

Tang MH, Porder S, Lovett GM (2012) Species differences in nitrate reductase activity are unaffected by nitrogen enrichment in northeastern US forests. For Ecol Manage 275:52-59. doi: 10.1016/j.foreco.2012.03.006

Templer PH, Dawson TE (2004) Nitrogen uptake by four tree species of the Catskill Mountains, New York: implications for forest N dynamics. Plant Soil 262:251-261. doi: 10.1023/B:PLSO.0000037047.16616.98 
Thornton B, Osborne SM, Paterson E, Cash P (2007) A proteomic and targeted metabolomic approach to investigate change in Lolium perenne roots when challenged with glycine. J Exp Bot 58:1581-1590. doi: 10.1093/jxb/er1294

Vanguelova EI, Hirano Y, Eldhuset TD, Sas-Paszt L, Bakker MR, Puttsepp U, Brunner I, Lohmus K, Godbold D (2007) Tree fine root Ca/Al molar ratio - Indicator of Al and acidity stress. Plant Biosyst 141:460-480. doi: Doi 10.1080/11263500701626192

Watanabe T, Osaki M, Tadano T (1998) Effects of nitrogen source and aluminum on growth of tropical tree seedlings adapted to low pH soils. Soil Sci Plant Nutr 44:655-666. doi: $10.1080 / 00380768.1998 .10414489$

Zhou X, Gu Z, Xu H, Chen L, Tao G, Yu Y, Li K (2016) The effects of exogenous ascorbic acid on the mechanism of physiological and biochemical responses to nitrate uptake in two rice cultivars (Oryza sativa L.) under aluminum stress. J Plant Growth Regul 35:1013-1024. doi: 10.1007/s00344-016-9599-9 
Chapter 4. The response of tree ring $\delta^{15} \mathrm{~N}$ to whole-watershed urea fertilization at the Fernow Experimental Forest, WV

Reprinted from

Burnham MB, McNeil BE, Adams MB, Peterjohn WT. (2016) The response of tree ring $\delta^{15} \mathrm{~N}$ to a whole-watershed fertilization with urea at the Fernow Experimental Forest, WV.

Biogeochemistry 130(1): 133-145. DOI: 10.1007/s10533-016-0248-y

*Minor modifications incorporated at the request of committee members. 


\subsection{Abstract}

Plant tissue $\delta^{15} \mathrm{~N}$ is frequently used as a proxy for $\mathrm{N}$ availability and $\mathrm{N}$ cycle dynamics, and the $\delta{ }^{15} \mathrm{~N}$ signature of tree rings could potentially be used to reconstruct past changes in the $\mathrm{N}$ cycle due to forest disturbance or anthropogenic $\mathrm{N}$ deposition. However, there are substantial uncertainties regarding how effectively tree ring $\delta^{15} \mathrm{~N}$ records $\mathrm{N}$ cycle dynamics. We used increment tree cores from a forested watershed that received a one-time application of urea, along with the long-term stream water chemistry record from that watershed and a nearby reference watershed, to determine the effectiveness of tree ring $\delta^{15} \mathrm{~N}$ in recording a change in $\mathrm{N}$ availability, and whether its effectiveness differed by tree species or associated mycorrhizal type. Tree ring $\delta^{15} \mathrm{~N}$ of three species increased rapidly (within $\sim 1-3$ years) following fertilization (Quercus rubra, Fagus grandifolia, and Prunus serotina), while that of Liriodendron tulipifera did not respond to fertilization but increased $\sim 10$ years later. Tree ring $\delta^{15} \mathrm{~N}$ tended to remain elevated throughout the measured time period (1967-2000), well past the pulsed fertilization response in stream water. This extended $\delta^{15} \mathrm{~N}$ response may be partially caused by chronic atmospheric $\mathrm{N}$ deposition in the region, which also contributed to greater losses of nitrate in stream water by $\sim 1980$. Additionally, local recycling of $\mathrm{N}$ compounds, and retranslocation of $\mathrm{N}$ within the trees, may account for the persistence of elevated tree ring $\delta^{15} \mathrm{~N}$ levels beyond the direct fertilization effects. Collectively, these results confirm that tree ring $\delta^{15} \mathrm{~N}$ from some species can document the onset of historical changes in the $\mathrm{N}$ cycle. We suggest that studies utilizing tree ring $\delta^{15} \mathrm{~N}$ as a proxy for long-term $\mathrm{N}$ cycle dynamics should look for a consistent pattern of change among several species rather than relying on the record from a single species. 


\subsection{Introduction}

Anthropogenic reactive $\mathrm{N}$ input into terrestrial ecosystems has more than doubled over the past century (Galloway et al. 2004), stimulating extensive research on the short- and long-term effects of $\mathrm{N}$ deposition, and the recovery of natural ecosystems as deposition has declined in some regions (Gundersen et al. 1998; Adams et al. 2007; Likens and Buso 2012). However, investigating long-term changes requires long-term records of $\mathrm{N}$ cycling in order to identify trends and characterize baseline conditions. Unfortunately, continuous measurements of stream water $\mathrm{N}$ are spatially and temporally limited, with the longest record, that we are aware, beginning in 1964 (Knapp et al. 2012; Argerich et al. 2013). In the absence of numerous, longterm records of $\mathrm{N}$ cycling, tree ring $\delta^{15} \mathrm{~N}$ could serve as an indicator of the $\mathrm{N}$ status of an area over time and yield valuable information about the timing and extent of the impacts resulting from $\mathrm{N}$ deposition.

Stable isotopes are used to study numerous biogeochemical and physiological processes, and ${ }^{15} \mathrm{~N}$ has emerged as a tool in N cycling research (Pardo et al. 2006; Pardo and Nadelhoffer 2012). In particular, plant tissue $\delta^{15} \mathrm{~N}$ can act as an integrator of complex $\mathrm{N}$ cycle processes occurring in the soil (Robinson 2001), and the use of tree ring $\delta^{15} \mathrm{~N}$ to study past $\mathrm{N}$ cycle dynamics has increased over the past two decades (Gerhart and McLauchlan 2014). When N availability increases, elevated rates of nitrification can lead to the loss of ${ }^{15} \mathrm{~N}$-depleted $\mathrm{NO}_{3}$ in stream water, resulting in an increase in the $\delta^{15} \mathrm{~N}$ of the remaining plant available $\mathrm{N}$ pool (Hogberg 1997; Pardo et al. 2002). Elevated $\mathrm{N}$ availability can also increase the otherwise low levels of gaseous $\mathrm{N}$ losses in deciduous broadleaf forests (Peterjohn et al. 1998; Venterea et al. 2004; Wallenstein et al. 2006), which favors the removal of ${ }^{15} \mathrm{~N}$-depleted $\mathrm{N}$ compounds (Yoshida 1988; Barford et 
al. 1999; Sebilo et al. 2003) and can have a substantial impact on soil $\delta^{15} \mathrm{~N}$ (Houlton et al. 2006; Wexler et al. 2014). The potential usefulness of plant tissue $\delta^{15} \mathrm{~N}$ as a record of shifts in the $\mathrm{N}$ cycle is supported by evidence from disturbance events such as clear-cutting or selective tree removal (Pardo et al. 2002; Bukata and Kyser 2005; Beghin et al. 2011; Falxa-Raymond et al. 2012), from studies of $\mathrm{N}$ deposition gradients (Saurer et al. 2004), and from long-term N deposition data (McLauchlan et al. 2007; Hietz et al. 2010; Sun et al. 2010). However, there is still a high degree of unexplained variation in wood stable $\mathrm{N}$ isotope records.

Some variability among species in tree ring $\delta^{15} \mathrm{~N}$ response could be due to their type of mycorrhizal association, especially in mixed forests where anthropogenic $\mathrm{N}$ deposition is prevalent. While arbuscular mycorrhizae (AM) are thought to have a minor role in organic $\mathrm{N}$ mobilization, ectomycorrhizal (ECM) fungi can cleave organic polymers to access bound $\mathrm{N}$ (Read and Perez-Moreno 2003) and transfer strongly ${ }^{15} \mathrm{~N}$-depleted compounds from ECM fungi to the host plant (Hobbie and Hobbie 2006; Hobbie and Högberg 2012). It is also thought that ECM plants may be less dependent on organic $\mathrm{N}$ in temperate ecosystems where mineral $\mathrm{N}$ availability is higher than in more northern latitudes (Lilleskov et al. 2002; Mayor et al. 2015). However, when $\mathrm{N}$ availability changes, it is unclear how rapidly the ECM community composition might shift, and how rapidly the $\mathrm{N}$ acquisition role of ECM fungi might change (Treseder 2004; Hawkins et al. 2015). If a reduction in the reliance on organic $\mathrm{N}$ is slow (or doesn't occur), then the transfer of ${ }^{15} \mathrm{~N}$-depleted compounds to the host plant by ECM fungi may delay the appearance of a plant $\delta^{15} \mathrm{~N}$ response to changes in inorganic $\mathrm{N}$ availability. Thus, we expect that the record of tree ring $\delta^{15} \mathrm{~N}$ in $\mathrm{AM}$ species should be more responsive to changes in the availability of inorganic $\mathrm{N}$ than the record of tree ring $\delta^{15} \mathrm{~N}$ in ECM tree species, but changes 
in the reliance by ECM trees on organic $\mathrm{N}$ sources could make the interpretation of tree ring $\delta^{15} \mathrm{~N}$ signals in these species more challenging.

Even within an individual tree, the $\mathrm{N}$ content $(\% \mathrm{~N})$ of tree rings typically increases dramatically in the outermost rings due to the movement of labile $\mathrm{N}$ compounds toward actively growing tissue (Elhani et al. 2003; Hart and Classen 2003; Härdtle et al. 2014). This could occur due to direct movement of mobile $\mathrm{N}$ compounds across rings, or internal recycling of $\mathrm{N}$ compounds (Hagen-Thorn et al 2006). Thus, the movement of $\mathrm{N}$ compounds within the tree has the potential to blur the isotopic signal by spreading it over multiple years (Hart and Classen 2003; Tomlinson et al. 2014). Furthermore, some of the physiological transformations $\mathrm{N}$ compounds undergo from uptake to storage in woody tissue can discriminate against $\delta^{15} \mathrm{~N}$ (Kalcsits et al. 2014). For example, Pardo et al. (2013) found variability in the $\delta^{15} \mathrm{~N}$ signal between different tree tissues, pointing to fractionation as $\mathrm{N}$ is transported throughout the tree. However, if the fractionations that impact the $\delta^{15} \mathrm{~N}$ composition of transported $\mathrm{N}$ are consistent across years, then the signal preserved in tree rings should still reflect temporal changes in the openness of the $\mathrm{N}$ cycle.

To determine the effectiveness of different tree species as recorders of past $\mathrm{N}$ cycling, a known shift or disturbance in the $\mathrm{N}$ cycle can be used as a reference point. Past studies have used events such as forest disturbance to investigate tree ring $\delta^{15} \mathrm{~N}$ response (Bukata and Kyser 2005; FalxaRaymond et al. 2012), and numerous studies have attributed a change in plant tissue $\delta^{15} \mathrm{~N}$ to increases in N deposition (Choi et al. 2005; Bukata and Kyser 2007; Savard et al. 2009; Hietz et al. 2011; Jung et al. 2013). McLauchlan and Craine (2012) found differences in the temporal 
trends of tree ring $\delta^{15} \mathrm{~N}$ between species, but no study has directly compared the temporal response of $\delta^{15} \mathrm{~N}$ in tree rings of multiple co-existing species to a known, and independentlymeasured past disturbance to the $\mathrm{N}$ cycle. Thus, the purpose of this study was to examine the effectiveness of different species in recording a known shift in $\mathrm{N}$ cycle dynamics in tree ring $\delta^{15}$ N. Similar to a pulse-chase experiment, we used a one-time, whole-watershed, fertilization event from 1971 that caused a distinct, short-term increase in a continuously measured stream water $\mathrm{N}$ record. By comparing the tree ring and stream water records from both within this single-dose fertilized watershed, as well as a nearby reference watershed, we examined the following hypotheses:

1. Tree ring $\delta^{15} \mathrm{~N}$ would increase in response to fertilization, followed by a decline back to pre-fertilization levels.

2. The reduction of $\delta^{15} \mathrm{~N}$ back to pre-fertilization levels would not be as rapid as the return of stream water chemistry because tree ring $\mathrm{N}$ could be retranslocated from senescent tissues and reused, and/or recycled within the local $\mathrm{N}$ cycle.

3. The tree ring $\delta^{15} \mathrm{~N}$ record in $\mathrm{AM}$ species would be more responsive to changes in $\mathrm{N}$ cycling than that of ECM species, and more closely parallel changes in stream water $\mathrm{NO}_{3}$ concentration.

\subsection{Methods}

Study site

We sampled tree rings from multiple species in a 30-ha experimental watershed (WS 1), as well as from one tree species in a 39-ha reference watershed (WS 4) at the Fernow Experimental Forest (FEF) in Tucker County, WV. The predominant soil is Calvin channery silt loam and is 
relatively acidic $(\mathrm{pH} \sim 4.5-5)$. The $\mathrm{FEF}$ receives approximately $145 \mathrm{~cm}$ annual precipitation (Kochenderfer 2006). Stream flow in both watersheds is continuously monitored using $120^{\circ} \mathrm{V}$ notch weirs (Trimble 1977), and monthly stream water conductivity and flow-weighted $\mathrm{NO}_{3}$ concentration have been measured since 1958 and 1970, respectively. Peterjohn et al. (1996) estimated that the average wet $\mathrm{N}$ deposition rate was $\sim 6.7 \mathrm{~kg} \mathrm{~N} \mathrm{ha}^{-1} \mathrm{yr}^{-1}$ from 1982 to 1993 . The experimental watershed was commercially clear-cut in the winter of 1957-1958, with all merchantable trees removed down to approximately $15 \mathrm{~cm} \mathrm{DBH}$; prior to this cut, the watershed was a 50-year-old uneven aged stand dominated by Quercus, Acer, Liriodendron, Prunus, and Fagus species (Reinhart et al 1963). In 1970, the stand averaged $\sim 10 \mathrm{~m}$ in height and was dominated by these same species as well as Tilia americana (Patric and Smith 1978). In May, 1971, the experimental watershed received a one-time, $617.75 \mathrm{~kg} \mathrm{ha}^{-1}$, aerial application of urea, which added $288 \mathrm{~kg} \mathrm{~N} \mathrm{ha}^{-1}$ and caused a rapid, short-lived increase in stream water conductivity and $\mathrm{NO}_{3}$ (Patric and Smith 1978). Based on recent measurements from a nearby watershed, the $\mathrm{N}$ content in the top $5 \mathrm{~cm}$ of mineral soil was $\sim 1514 \mathrm{~kg} \mathrm{ha}^{-1}$, and so the added $\mathrm{N}$ likely was $\sim 14-$ $20 \%$ of the $\mathrm{N}$ originally present in top $5 \mathrm{~cm}$ of soil. Although no $\delta^{15} \mathrm{~N}$ measurement was made on the applied urea at that time, typical $\delta^{15} \mathrm{~N}$ values for urea range from $-2.3 \%$ to $-1 \%$ (Nommik et al. 1994; Choi et al. 2002; Zhou et al. 2013), and potentially up to 1.3\%o (Li and Wang 2008). While no measurements of net $\mathrm{N}$ mineralization or nitrification rates have ever been made in WS 1, evidence for a positive relationship between net nitrification rates and $\mathrm{NO}_{3}$ level in soil and stream water exists for other areas of the FEF, including the reference watershed (Peterjohn et al. 1996; Peterjohn et al. 1999; Gilliam and Adams 2011). From these results, we think it is likely that the rate of net nitrification in the soils of WS 1 increased rapidly after fertilization, causing the observed increase in stream water $\mathrm{NO}_{3}$ concentration. 
Tree core collection and analysis

We collected tree cores from four Fagus grandifolia and Quercus rubra trees (ECM) and five Prunus serotina and Liriodendron tulipifera trees (AM) in the fertilized watershed (WS 1), and from three large Liriodendron tulipifera trees located near the weir used for stream water measurements in the reference watershed (WS 4). Using a 5-mm increment borer (Mora of Sweden, Mora, Sweden), we extracted two cores parallel to the topographical contour from each tree, rinsing the increment borers with deionized water between trees. Trees were selected at 5 points along a mid-elevation band to be evenly spaced through the watershed to control for potential elevational effects on the $\delta^{15} \mathrm{~N}$ signal in plant available $\mathrm{N}$ pools (Garten 1993). At each point, we cored the largest canopy tree within $\sim 30 \mathrm{~m}$, with a minimum DBH of $30 \mathrm{~cm} . F$. grandifolia trees tended to be smaller in girth, and so a minimum DBH of $25 \mathrm{~cm}$ was used for this species. We sampled the wood tissue from each individual tree ring between 1967 and 1980 - a range surrounding the year of urea application (1971). In addition, we pooled 5-year tree-ring segments for 1981-1985, 1986-1990, 1991-1995, and 1996-2000. Since the temporal dynamics of fertilizer application and stream water chemistry response were known, this made it possible to detect any inward translocation of the $\delta^{15} \mathrm{~N}$ signal to earlier tree rings, and also whether changes in the tree ring $\delta^{15} \mathrm{~N}$ signal lasted longer than those in stream water chemistry (Elhani et al. 2003).

We mounted, sanded, measured, and cross-dated one core from each tree (Stokes and Smiley 1996), calculated basal area increment (BAI) using ring widths and tree diameter measurements 
at breast height, and assessed cross-dating accuracy using the dplR package in R (Bunn 2010).

The second core from each tree was sanded only lightly to minimize cross-contamination between rings. We separated years selected for isotope analysis from the core using a razor blade and ground the tissue to a fine powder using a dental amalgamator (Henry Schein, Inc., Melville, NY), wrapping approximately $5 \mathrm{mg}$ of ground tissue in tin capsules for isotope ratio gas chromatography-mass spectrometry analysis. Isotope analysis was completed by the University of Maryland Central Appalachians Stable Isotope Facility (Frostburg, MD). Due to variable results of wood N extraction techniques (reviewed by Gerhart and McLauchlan 2014), we analyzed raw wood tissue rather than performing any $\mathrm{N}$ extraction.

\section{Statistical analysis}

To reduce tree-to-tree differences in absolute $\delta^{15} \mathrm{~N}$ level while preserving the temporal trend, we standardized the tree ring $\delta^{15} \mathrm{~N}$ values for each tree by subtracting the within-tree average from each ring's value (Gerhart and McLauchlan 2014). While Gerhart and McLauchlan (2014) suggest that some studies standardize to the same mean within site to focus on temporal trends, we standardized within each tree due to species differences in $\delta^{15} \mathrm{~N}$ at our single site and tree differences within species at different locations within the watershed. Data were analyzed using a nested two-way factorial design with tree ring $\delta^{15} \mathrm{~N}$ as the response variable. For this analysis, we used the four years prior to fertilization (1967-1970) as a pre-treatment reference time period, while considering the four years following fertilization (1972-1975) to be the treatment time period. A two-way model was constructed with species nested within mycorrhizal type and year nested within pre- vs. post-fertilization time period. To test our hypotheses we focused on 
detecting a significant effect $(\alpha=0.05)$ due to the time period (pre- vs. post-fertilization), and due to the mycorrhizal type by time period interaction. A significant time period effect would indicate a change in tree ring $\delta^{15} \mathrm{~N}$ from the 4 years prior to fertilization to the 4 years after, and a significant interaction effect between time period and mycorrhizal type would indicate that the change in tree ring $\delta^{15} \mathrm{~N}$ from years prior to fertilization to years post-fertilization differs by mycorrhizal association (ECM or AM).

\subsection{Results}

Stream $\mathrm{NO}_{3} \&$ tree growth

Stream water conductivity (not shown) and $\mathrm{NO}_{3}$ were strongly correlated $(\mathrm{r}=0.765, \mathrm{P}<0.001)$ and peaked shortly after urea fertilization (Fig. 4-1) (Patric and Smith 1978). The peak in stream water $\mathrm{NO}_{3}$ was short-lived (lasting $\sim 3$ years), but $\mathrm{NO}_{3}$ concentrations never completely returned to pre-fertilization levels - with levels in $2006(\sim 100 \mu \mathrm{M})$ still 4x greater than pre-fertilization levels ( $\sim 25 \mu \mathrm{M}$ in 1970). In addition, there was a $57 \%$ increase in $\mathrm{NO}_{3}$ concentration from 1978$1979(75 \mu \mathrm{M})$ to $1980-1981(117 \mu \mathrm{M})$, an increase that coincided with a $145 \%$ increase (17 to 42 $\mu \mathrm{M}$ ) in stream $\mathrm{NO}_{3}$ concentration in the nearby reference watershed (WS 4).

Since not all trees were harvested from WS 1 in 1957-1958, 50\% of the trees we cored were established prior to 1957 . The ring width and BAI of all four species increased markedly $(51.4 \%$ for L. tulipifera to $178 \%$ for $F$. grandifolia) after the watershed was commercially clear-cut in 1957 (Fig. 4-2). This BAI increase was most apparent for $F$. grandifolia trees whose growth had 
been suppressed in the understory prior to 1957. A second increase in BAI $(\mathrm{P}<0.001)$ occurred during the five years after urea fertilization compared to the 5 years prior for three of the species we examined; L. tulipifera (189\%), P. serotina (118\%), and Q. rubra (45\%). There was no significant change $(\mathrm{P}=0.101)$ in $F$. grandifolia BAI following urea fertilization (Fig. 4-2).

\section{General species differences in $\delta^{15} N$}

The non-standardized average wood $\delta^{15} \mathrm{~N}$ signature across all years differed between species. Specifically, we found that $F$. grandifolia and $Q$. rubra had the highest mean $\delta^{15} \mathrm{~N}$ values ($0.322 \%$ and $-0.556 \%$, respectively), while the mean $\delta^{15} \mathrm{~N}$ value for P. serotina was significantly lower (-1.480\%o), and the value for L. tulipifera was significantly lower than all other species ($2.603 \%$ ). There was a positive correlation between ring width and tree ring $\delta^{15} \mathrm{~N}$ for $P$. serotina $(\mathrm{r}=0.623, \mathrm{P}<0.001)$ and $Q . r u b r a(\mathrm{r}=0.378, \mathrm{P}=0.006)$, and a negative correlation for $F$. grandifolia $(\mathrm{r}=-0.473, \mathrm{P}=0.002)$, while the correlation for L. tulipifera was not statistically significant. Non-standardized wood $\delta^{15} \mathrm{~N}$ also differed between species $(\mathrm{P}<0.001)$ for prefertilization rings and followed the same pattern as $\delta^{15} \mathrm{~N}$ averaged over all years. $F$. grandifolia and $Q . r u b r a$ had the highest pre-fertilization $\delta^{15} \mathrm{~N}$ values $(-1.039 \%$ and $-1.201 \%$, respectively), while $P$. serotina $\delta^{15} \mathrm{~N}$ was lower (-2.340\%) and L. tulipifera was lowest of all species ($2.943 \%$ ).

Species differences in fertilization effects on $\delta^{15} \mathrm{~N}$

When averaged across all species, standardized tree ring $\delta^{15} \mathrm{~N}$ increased $0.84 \%$ from the four years before urea fertilization to the four years after $(\mathrm{P}<0.001)$. However, the magnitude of the 
increase differed by species, with $Q$. rubra, F. grandifolia, and $P$. serotina all showing a $>1 \%$ o increase in tree ring $\delta^{15} \mathrm{~N}$, while $L$. tulipifera did not respond noticeably to the fertilization event (Fig. 4-3). In Q. rubra, tree ring $\delta^{15} \mathrm{~N}$ increased 1.56\% from 1968 through 1973, while $F$. grandifolia tree ring $\delta^{15} \mathrm{~N}$ increased $1.16 \%$ between 1970 and 1972. $P$ serotina tree ring $\delta^{15} \mathrm{~N}$ increased 1.41\%o from 1971 through 1974.

Grouping tree species by mycorrhizal type indicated that the tree ring $\delta^{15} \mathrm{~N}$ of ECM species increased more strongly due to fertilization than that of AM species $(\mathrm{P}=0.0099)$. However, this difference was driven by the tree ring $\delta^{15} \mathrm{~N}$ signal for one of the two AM species examined ( $L$. tulipifera), and when L. tulipifera was not considered, the three other species showed similar increases in tree ring $\delta^{15} \mathrm{~N}$ after fertilization with respect to their timing and overall magnitude.

\section{Timing and duration of the $\delta^{15} N$ response}

Tree ring $\delta^{15} \mathrm{~N}$ increased within 2 years of fertilization for three of the four species examined (Fig. 4-3). Of these three species, the increase did not precede fertilization for F. grandifolia. For $P$. serotina the $\delta^{15} \mathrm{~N}$ signal increased every year from 1967-1974, including a trend towards a significant increase from 1967-1971 $(\mathrm{P}=0.091)$. However, of the total increase found for $P$. serotina, most (76.6\%) of it occurred after fertilization. The increase in tree ring $\delta^{15} \mathrm{~N}$ for $Q$. rubra appeared to begin $\sim 2$ years prior to fertilization, with most (62.8\%) of the maximum increase occurring prior to fertilization. Wood $\delta^{15} \mathrm{~N}$ for F. grandifolia and P. serotina increased after fertilization, with $F$. grandifolia reaching a plateau after 1972 (at $\sim 0.1 \%$ non-standardized $\delta^{15} \mathrm{~N}$ ) and P. serotina peaking in 1974 (at $\sim 0.82 \%$ ) and stabilizing after 1977 (at $\sim 0.2 \%$ ). Wood 
$\delta^{15} \mathrm{~N}$ for Q. rubra began to increase 2 years prior to fertilization and plateaued from 1973 through 1980 ( 0.02\% non-standardized). After 1980, the tree ring $\delta^{15} \mathrm{~N}$ for $Q$. rubra declined and remained $\sim 1 \%$ lower than the years immediately post-fertilization (1973-1980).

Although there was a distinct, and short-lived, peak in stream water $\mathrm{NO}_{3}$, this peak was not as evident in the tree ring $\delta^{15} \mathrm{~N}$ record of any species we examined (Fig. 4-3). Rather, tree ring $\delta^{15} \mathrm{~N}$ increased within 2 years of fertilization, but tended to level off near its highest value or only gradually decline. Tukey's HSD post-hoc analysis indicated no reduction in tree ring $\delta^{15} \mathrm{~N}$ during 1976-1980 when compared to $1972-1975$, the four years immediately after fertilization. In particular, $\delta^{15} \mathrm{~N}$ of both $Q$. rubra and F. grandifolia remained elevated through 1980. And although the isotopic signature of $P$. serotina trees during 1976-1979 appears to be lower than during the peak years of 1972-1975, this was not statistically significant $(\mathrm{P}=0.713)$. Considering the full extent of the post-fertilization tree ring record (through the year 2000), we found that tree ring $\delta^{15} \mathrm{~N}$ in species responding to fertilization never returned to the pre-fertilization levels (Fig. 4-3). Even for Q. rubra tree ring $\delta^{15} \mathrm{~N}$, which declined from $1980-2000$, remained $\sim 0.8 \%$ above the initial pre-fertilization tree ring $\delta^{15} \mathrm{~N}$. The tree ring $\delta^{15} \mathrm{~N}$ of both $F$. grandifolia and $P$. serotina remained at levels similar to 1975-1980 throughout the entire tree ring record. However, while L. tulipifera tree ring $\delta^{15} \mathrm{~N}$ did not shift in response to fertilization, a large increase ( 1.25\%) occurred between 1979 and 1985, and was sustained through 2000.

Increases in tree ring $\delta^{15} \mathrm{~N}$ did not correspond with heartwood-sapwood boundaries in AM species we examined (Fig. 4-3). The heartwood-sapwood boundaries in L. tulipifera trees 
occurred during 1989-1990, with the exception of one tree in which the transition was in the 1980 ring. In P. serotina, all heartwood-sapwood transitions occurred during the late-1990s. In the two ECM species, the heartwood-sapwood transitions were not visible on dried, sanded cores.

\subsection{Discussion}

Following the urea fertilization to WS 1 in 1971, stream water measurements showed a significant increase in $\mathrm{NO}_{3}$ concentration, very likely due to an increase in the rates of soil net nitrification (Peterjohn et al. 1996; Peterjohn et al. 1999). This increased loss of $\mathrm{NO}_{3}$ to stream water likely caused a disproportionate amount of the isotopically lighter isotope to leave the forested catchment (Spoelstra et al. 2010), which should increase in the $\delta^{15} \mathrm{~N}$ signal in the residual pool of plant available N. Within $\sim 1-3$ years of the whole-watershed fertilization event, this increase in $\delta^{15} \mathrm{~N}$ was preserved in the tree rings of 3 of the 4 species that we examined. We found little evidence for significant movement of the $\delta^{15} \mathrm{~N}$ signal across more than a few annual rings, with only $Q$. rubra tree ring $\delta^{15} \mathrm{~N}$ showing a statistically significant increase prior to fertilization, and only by $\sim 2$ years. Another species (P. serotina) also showed a trend towards an increase prior to fertilization, but the increase was minor relative to the rate of change that occurred after fertilization. Although some $\mathrm{N}$ compounds may be mobile within the tree (Elhani et al. 2003), our results show that movement across rings does not substantially impact the tree ring $\delta^{15} \mathrm{~N}$ signal and its response to local $\mathrm{N}$ cycle disturbance - at least for species we examined. Thus, our findings indicate that tree ring $\delta^{15} \mathrm{~N}$ from some species can effectively document the onset of a known change in the $\mathrm{N}$ cycle. 
Consistent with our expectations, the reduction of $\delta^{15} \mathrm{~N}$ back to pre-fertilization levels was not as rapid as the return of stream water chemistry. However, we were surprised to observe that, even 29 years after the fertilization event, the tree ring $\delta^{15} \mathrm{~N}$ signals showed almost no return to prefertilization levels. In fact, the observed short-lived duration of the peak in stream $\mathrm{NO}_{3}$ levels was not captured by any of the tree ring isotope records. In the species showing an isotopic response to urea fertilization, a decline in tree ring $\delta^{15} \mathrm{~N}$ either was not detectable $(F$. grandifolia and $P$. serotina $)$ or was significantly delayed ( $Q$. rubra) relative to the measured decline in stream $\mathrm{NO}_{3}$ concentrations.

The mechanisms responsible for the lack of any substantial reduction in the post-fertilization $\delta^{15} \mathrm{~N}$ signal in tree rings were not determined, but may include both plant and soil processes. The annual retranslocation of approximately $50 \%$ of foliar $\mathrm{N}$ during autumn senescence (HagenThorn et al. 2006) causes some $\mathrm{N}$ taken up in one year to be stored and potentially available for the growth of new tissues in subsequent years. The $\mathrm{N}$ lost in litterfall may also be mineralized and taken up by the tree as it cycles through the soils near a given tree (Zeller et al. 2000). In addition, the persistence of elevated stream water $\mathrm{NO}_{3}$ compared to pre-fertilization estimates (Fig. 4-1) indicates that the soil $\mathrm{N}$ cycle was altered well past the years immediately following fertilization. Thus, it appears that the combination of long-term changes in soil $\mathrm{N}$ cycling, internal retranslocation, and local recycling of $\mathrm{N}$ may explain the extended duration of elevated tree ring $\delta^{15} \mathrm{~N}$ beyond the urea fertilization event. 
Contrary to our expectations, a clear record of an acute urea fertilization event was present in both ECM and AM tree species. Research in boreal forests and tundra suggests that ECM fungi aid in $\mathrm{N}$ mobilization and acquisition by their host plant, and the transfer of $\mathrm{N}$ compounds from fungi to the plant host appears to strongly discriminate against ${ }^{15} \mathrm{~N}$, leaving the fungal tissue enriched and the plant tissue depleted in ${ }^{15} \mathrm{~N}$ (Hobbie and Hobbie 2006; Craine et al. 2009). However, these findings may apply primarily to low-N cycling ecosystems. Furthermore, there is considerable overlap in $\delta^{15} \mathrm{~N}$ values between ECM and AM species across the globe (Craine et al. 2009), and the signature is not always lower in ECM species, even in northern alpine climates (Makarov et al. 2014). In temperate forests, ECM tree species can also have higher tissue $\delta^{15} \mathrm{~N}$ values than AM species (Pardo et al. 2013). This may be especially true in areas of high $\mathrm{N}$ availability and regions that have historically received high $\mathrm{N}$ inputs from the atmosphere where ECM trees may depend less on their fungal symbionts for meeting their $\mathrm{N}$ demand (Read and Perez-Moreno 2003), and the $\delta^{15} \mathrm{~N}$ of ECM plant tissue should more closely reflect that of the available soil $\mathrm{N}$. Indeed, the $\delta^{15} \mathrm{~N}$ of ECM species in this study was not consistently lower than that of AM species prior to fertilization, and the observed increase in tree ring $\delta^{15} \mathrm{~N}$ after fertilization occurred in both AM and ECM species.

Among the three responsive tree species, the fertilization event was more apparent in the temporal change in $\delta^{15} \mathrm{~N}$ than in any change in growth. While tree ring width and BAI trends are commonly used to detect and reconstruct a variety of environmental changes (fire, drought, etc.), our data suggest that tree ring $\delta^{15} \mathrm{~N}$, rather than growth, is a stronger indicator of a disturbance in the $\mathrm{N}$ cycle. This was especially evident in the results obtained from $F$. grandifolia where tree ring $\delta^{15} \mathrm{~N}$ increased $1.16 \%$ after fertilization with no detectable change in BAI. Since a variety of 
factors other than $\mathrm{N}$ availability (light, water, etc.) can influence growth, we suggest that using tree ring $\delta^{15} \mathrm{~N}$ is most appropriate when studying changes in the $\mathrm{N}$ cycle.

In addition to enhanced nitrification and the loss of ${ }^{15} \mathrm{~N}$-depleted $\mathrm{NO}_{3}$, other aspects of the $\mathrm{N}$ cycle and urea fertilization could have affected the $\delta^{15} \mathrm{~N}$ of the pool of plant available N. First, the isotopic composition of the fertilizer could have changed the $\delta^{15} \mathrm{~N}$ of the soil $\mathrm{N}$ pool regardless of $\mathrm{NO}_{3}$ leaching. Since samples of the fertilizer used in 1971 were not archived, or their isotopic composition measured, it is impossible to know the exact $\delta^{15} \mathrm{~N}$ of the fertilizer that was applied to WS 1 . However, typical $\delta^{15} \mathrm{~N}$ values for urea fertilizer range from $-2.3 \%$ to $-1 \%$ o (Nommik et al. 1994; Choi et al. 2002; Zhou et al. 2013) but can be as high as 1.3\%o (Li and Wang 2008). Thus, the increase in plant $\delta^{15} \mathrm{~N}$ may be partially a signal from the urea $\delta^{15} \mathrm{~N}$ if it were in the $0-1 \%$ range. Second, an ammonia odor, and moss and leaf damage, were reported in the watershed after fertilization, indicating that there was substantial ammonia volatilization after urea addition (Patric and Smith 1978). Indeed, it is thought that $\sim 50 \%$ of the urea added was volatilized and lost as ammonia compared to an estimated loss of $\sim 20 \%$ in elevated stream-water $\mathrm{N}$ losses (Patric and Smith 1978). And any ammonia volatilization should increase the plant tissue $\delta^{15} \mathrm{~N}$ since this process favors the loss of the lighter isotope, leaving the pool of plantavailable ammonium more enriched in ${ }^{15} \mathrm{~N}$ (Mizutani et al. 1986; Mizutani and Wada 1988). Finally, it is possible that discrimination against ${ }^{15} \mathrm{~N}$ by the loss of other $\mathrm{N}$ gases - and ${ }^{15} \mathrm{~N}$ enrichment of the available $\mathrm{N}$ pool - resulted from increased rates of nitrification and denitrification (Wexler et al. 2014; Mnich and Houlton 2015). However, although fertilizer additions can enhance the loss of $\mathrm{N}$ gases (Castro et al. 1994; Venterea et al. 2004), the magnitude of these losses in temperate forests is often considered to be low relative to the 
magnitude of $\mathrm{N}$ losses in stream water (Campbell et al. 2004). Thus, the changes in tree ring $\delta^{15} \mathrm{~N}$ we observed may reflect a combination of increased nitrification leading to an enhanced loss of $\mathrm{NO}_{3}$ in stream water, the $\delta^{15} \mathrm{~N}$ signature of the fertilizer that was added, or increased loss of $\mathrm{N}$ gases by ammonia volatilization, nitrification, and/or denitrification. However, the exact manner by which the $\delta^{15} \mathrm{~N}$ signal of plant available $\mathrm{N}$ was altered does not change our conclusions regarding the effects of mycorrhizal type on tree ring $\delta^{15} \mathrm{~N}$ response to $\mathrm{N}$ cycle disturbance, or the timing and persistence of the signal through time.

A striking and surprising result was the lack of response detected in L. tulipifera tree ring $\delta^{15} \mathrm{~N}$ after urea fertilization. The reason behind this result is unclear but may be attributable to an initially strong $\mathrm{N}$ limitation on their growth. Indeed, prior to fertilization L. tulipifera had the lowest values for tree ring $\delta^{15} \mathrm{~N}$ of any of the species we sampled, and fertilization with urea in 1971 led to substantial increases in BAI (189\% 3 years post-fertilization) and increased bud N concentrations in these trees (Patric and Smith 1978). Collectively, these observations suggest greater $\mathrm{N}$ retention, and a reduced loss of ${ }^{14} \mathrm{~N}$-depleted $\mathrm{NO}_{3}$ in the soils surrounding these young L. tulipifera trees. However, a greater $\mathrm{N}$ retention associated with this species is not likely to be a sufficient explanation since the large amount of ammonia volatilization should have enriched the residual pool of plant available ammonium with ${ }^{15} \mathrm{~N}$. Furthermore, we estimate the BAI stimulation due to fertilization of L. tulipifera would yield $\sim 21.2 \mathrm{~kg} \mathrm{yr}^{-1} \operatorname{tree}^{-1}$ of additional growth, or $\sim 14,600 \mathrm{~kg} \mathrm{yr}^{-1} \mathrm{ha}^{-1}$ (Brenneman et al. 1978). Assuming a C content of $50 \%$ and a C:N ratio of 165 (Vitousek et al. 1988), then this amount of enhanced growth would sequester $44 \mathrm{~kg} \mathrm{~N} \mathrm{ha}^{-1} \mathrm{yr}^{-1}$, or only $\sim 15 \%$ of the added N. However, under a more complex set of circumstances it may be possible that the $\delta^{15} \mathrm{~N}$ of plant tissue could remain relatively unaltered if 
a given species relied primarily on nitrate, utilized it completely (i.e. little to no nitrate loss from the rhizosphere), and if the enrichment of the ammonium $\mathrm{N}$ pool with ${ }^{15} \mathrm{~N}$ by volatilization was offset by elevated rates of nitrification which produces $\mathrm{NO}_{3}$ that is depleted in ${ }^{15} \mathrm{~N}$.

While the reasons for the response of L. tulipifera trees compared to the other three species remain unknown, our results highlight how different species' tree ring $\delta^{15} \mathrm{~N}$ can respond differently to changes in local soil $\mathrm{N}$ processes. And further research on potential reasons for the surprising L. tulipifera result could be valuable, since Liriodendron species are common in areas of elevated $\mathrm{N}$ deposition and $\mathrm{N}$ cycle alteration in the US and China.

An equally striking result from this study was that the $\delta^{15} \mathrm{~N}$ record in tree rings of L. tulipifera increased dramatically $\sim 8$ years after fertilization. At this time, stream water $\mathrm{NO}_{3}$ increased in both WS 1 and a nearby mature (last cut ca. 1910), unfertilized watershed (WS 4). Furthermore, the tree ring $\delta^{15} \mathrm{~N}$ of older L. tulipifera trees also increased at this time in WS 4 (Fig. 4-4). The increase in WS 4 stream water $\mathrm{NO}_{3}$ has been attributed to $\mathrm{N}$ saturation caused by chronic additions of $\mathrm{N}$ from atmospheric deposition (Peterjohn et al. 1996), and the concurrent increase in WS 1 (Fig. 4-1) points to a similar effect in this watershed. The soil $\mathrm{N}$ pool was likely smaller when signs of $\mathrm{N}$ saturation due to long-term deposition appeared than immediately following urea application. The percent of the $\mathrm{N}$ pool transformed via nitrification was likely large during the $\mathrm{N}$ saturation shift in stream water $\mathrm{NO}_{3}$ (Peterjohn et al. 1996) compared to urea fertilization, when the soil $\mathrm{N}$ pool was much larger. This high percent nitrification, followed by $\mathrm{NO}_{3}$ loss under $\mathrm{N}$ saturation, could have a large impact on the residual plant available $\mathrm{N}$ pool. Thus, it is 
possible that the cumulative effects of $\mathrm{N}$ deposition on soil $\mathrm{N}$ cycling had a greater effect on $L$. tulipifera tree ring isotope composition than a one-time fertilization, and that the wood $\delta^{15} \mathrm{~N}$ of this species is a more effective indicator of the effects of long-term $\mathrm{N}$ deposition than the effects of a short-term $\mathrm{N}$ cycle disturbance.

To demonstrate how tree ring $\delta^{15} \mathrm{~N}$ might help to extend stream water $\mathrm{NO}_{3}$ records, we used the strong association between stream water $\mathrm{NO}_{3}$ concentration and L. tulipifera $\delta^{15} \mathrm{~N}$ from 1970 through 2005 in the WS $4(r=0.928)$ to estimate stream $\mathrm{NO}_{3}$ concentrations between 1920 and 1970 (Fig. 4-4). These estimates extend the existing long-term record (1970-2010) by an additional 50 years and suggest that prior to $\sim 1980$ stream $\mathrm{NO}_{3}$ concentrations were typically $\sim 15 \mathrm{uM}$ and relatively constant (C.V. $\sim 0.51$ ). While very useful at our study site, the value of using tree ring $\delta^{15} \mathrm{~N}$ records to reconstruct stream water $\mathrm{NO}_{3}$ levels at other locations may depend on conditions found at the FEF that may not apply elsewhere. These include high rates of net nitrification (Gilliam et al. 1996), a high percentage of mineralized $\mathrm{N}$ that is nitrified (Peterjohn et al. 1996), an apparent relationship between rates of soil nitrification and stream $\mathrm{NO}_{3}$ level (Gilliam and Adams 2011), and relatively low rates of gaseous $\mathrm{N}$ losses (Peterjohn et al. 1998; Venterea et al. 2004). It may also require a stable or relatively slowly changing $\delta^{15} \mathrm{~N}$ signature in atmospheric $\mathrm{N}$ deposition. While this cannot be confirmed at the FEF, Rose et al. (2015) reported precipitation $\delta^{15} \mathrm{~N}$ values of $-0.1 \%$ for the FEF in 2010, which is similar to regional values from 2000 (Elliott et al. 2007) and 1993-94 (Russell et al. 1998). 
In general, the results of this study support the potential utility of tree ring $\delta^{15} \mathrm{~N}$ in documenting significant changes in soil N cycling dynamics (Pardo and Nadelhoffer 2012; Gerhart and McLauchlan 2014), but show that the temporal record of tree ring $\delta^{15} \mathrm{~N}$ in different species can vary in response to the same change in the $\mathrm{N}$ cycle. As such, we suggest that research using tree ring $\delta^{15} \mathrm{~N}$ should utilize multiple species to obtain a synthetic view of the $\mathrm{N}$ cycle through time. In addition, tree ring $\delta^{15} \mathrm{~N}$ natural abundance should not be considered a recorder of the local $\mathrm{N}$ cycle with annual resolution due to the potential for inter-annual $\mathrm{N}$ movement, retranslocation, and recycling. Rather, it would be best used as an indicator of $\mathrm{N}$ cycle "openness", i.e., the proportion of $\mathrm{N}$ lost from the system as $\mathrm{NO}_{3}$ via nitrification or gaseous $\mathrm{N}$ losses, on a decadal time scale. Finally, additional measurements of site-specific soil $\mathrm{N}$ cycle processes, current or historic, can aid in the interpretation of the tree ring $\delta^{15} \mathrm{~N}$ signal and enhance our ability to draw conclusions about long-term $\mathrm{N}$ cycling dynamics. 


\subsection{Tables and Figures}

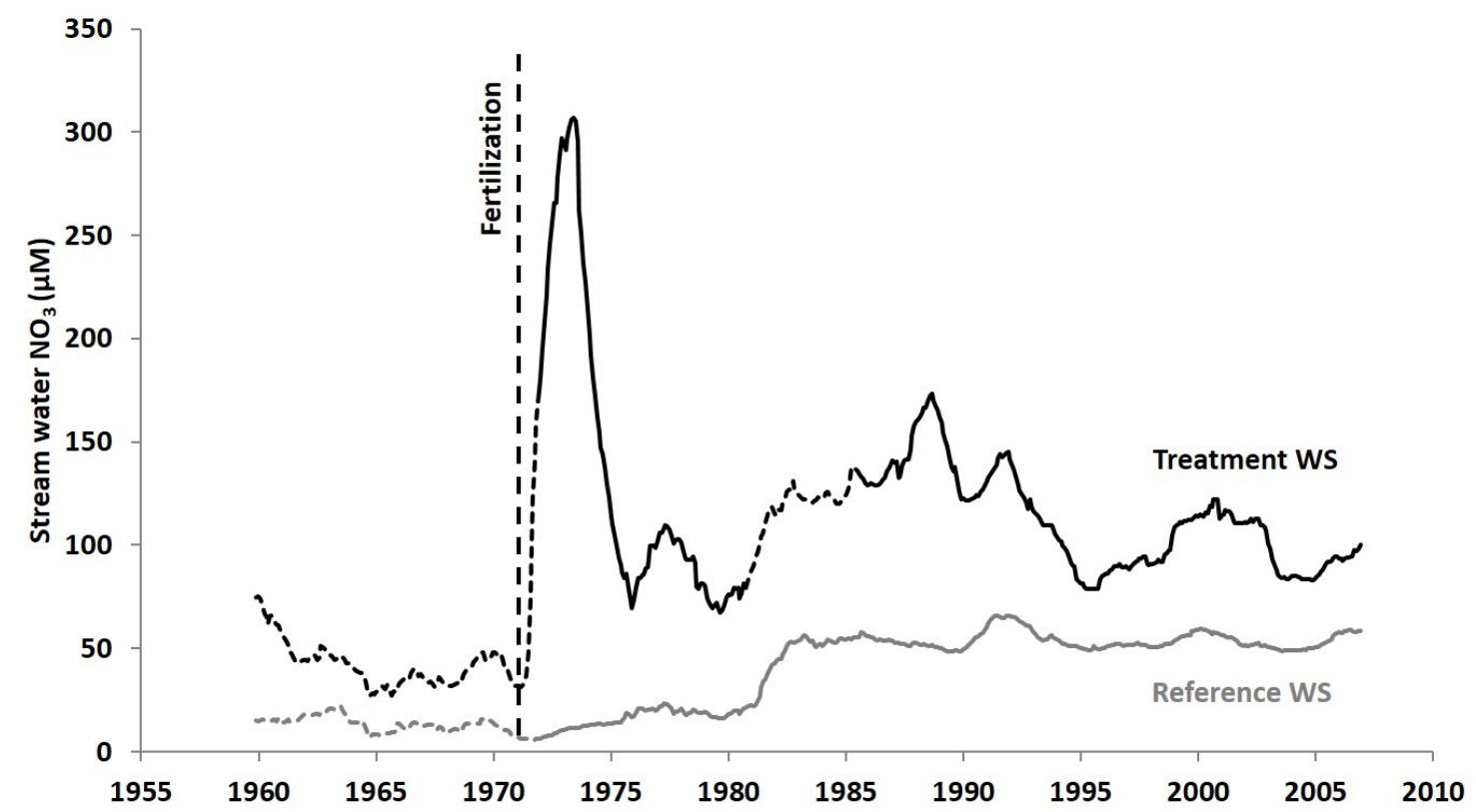

Figure 4-1. 24-month running mean of flow weighted monthly stream water $\mathrm{NO}_{3}$ in Fernow

Experimental Forest watershed 1 (clear-cut in 1957, fertilized in May, 1971) and watershed 4 (reference, cut circa 1900). Dashed line segments include estimated values based on the relationship between $\mathrm{NO}_{3}$ and stream water conductivity. 


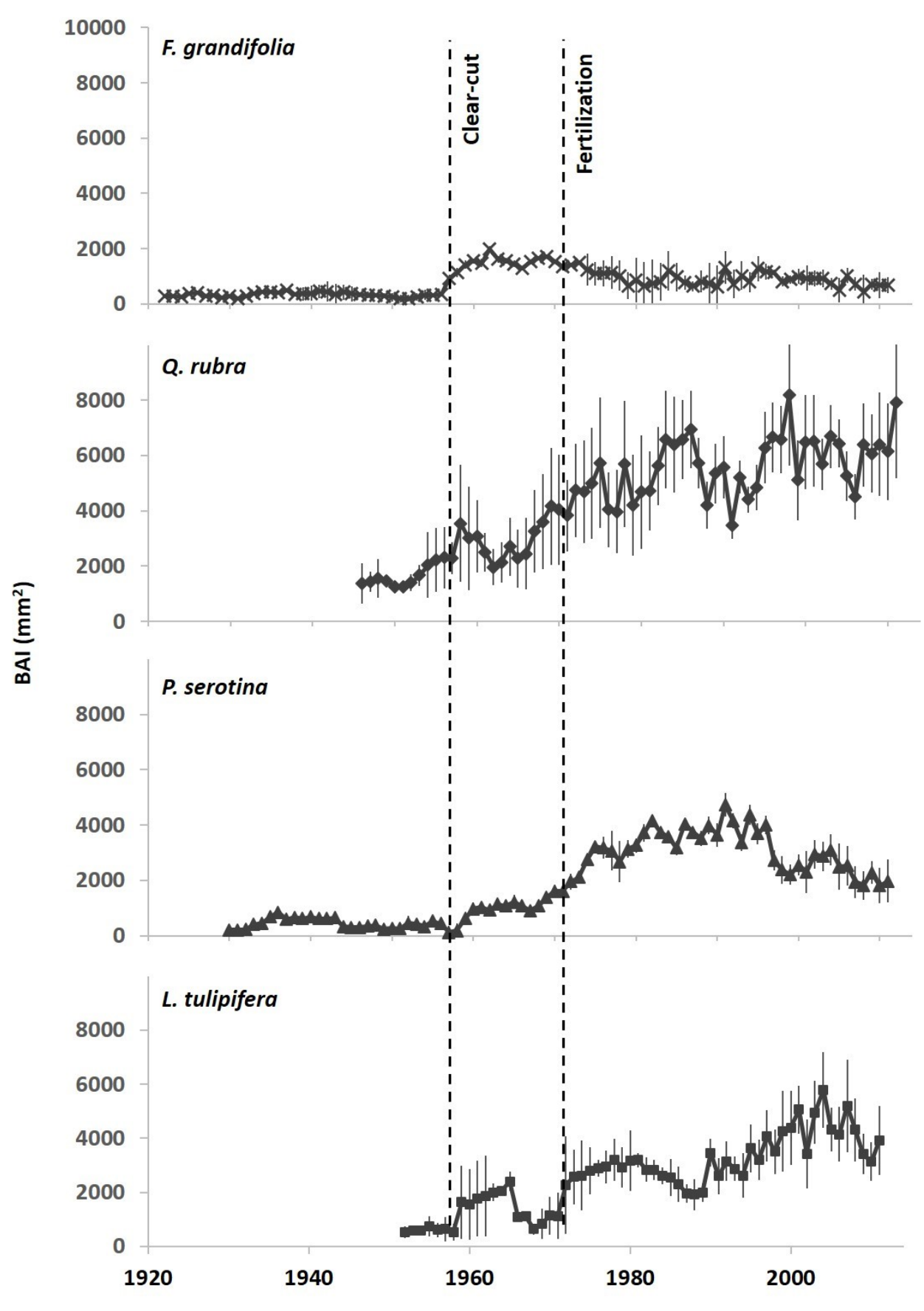

Figure 4-2. Mean basal area increment (BAI) of each species through time ( $\pm \mathrm{SE})$. 


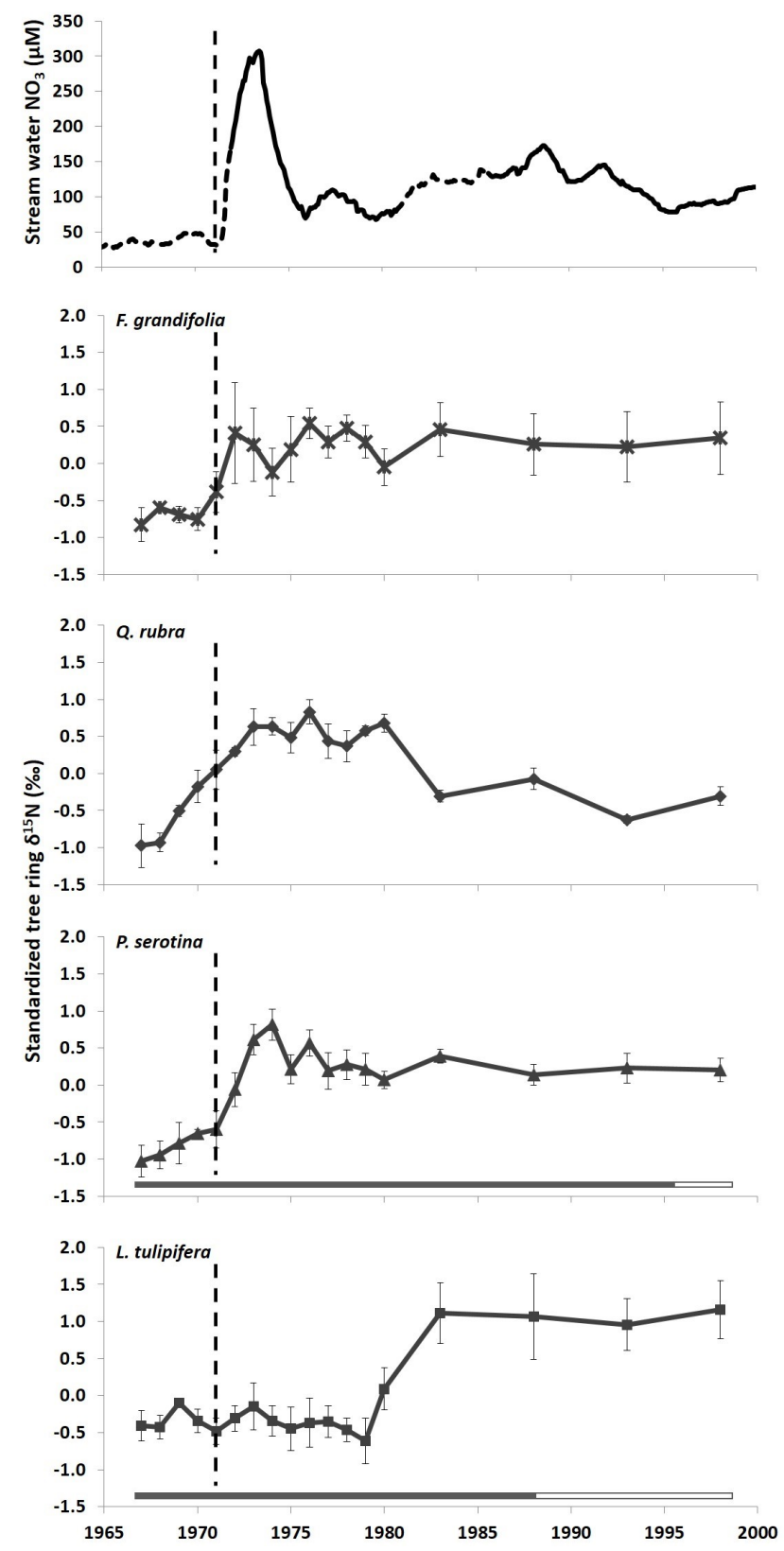

Figure 4-3. Mean annual standardized tree ring $\delta^{15} \mathrm{~N}$ by species $(\mathrm{n}=5$ cores for L. tulipifera and P. serotina, 4 for F. grandifolia and Q. rubra) and 24-month running mean of flow weighted monthly stream water $\mathrm{NO}_{3}$. Dashed vertical lines indicate the 1971 urea fertilization. Dashed line segment in top panel includes estimated values based on the relationship between $\mathrm{NO}_{3}$ and stream water conductivity. Average heartwood-sapwood boundaries are indicated by shaded (heartwood) and open (sapwood) horizontal bars in P. serotina and L. tulipifera panels. 


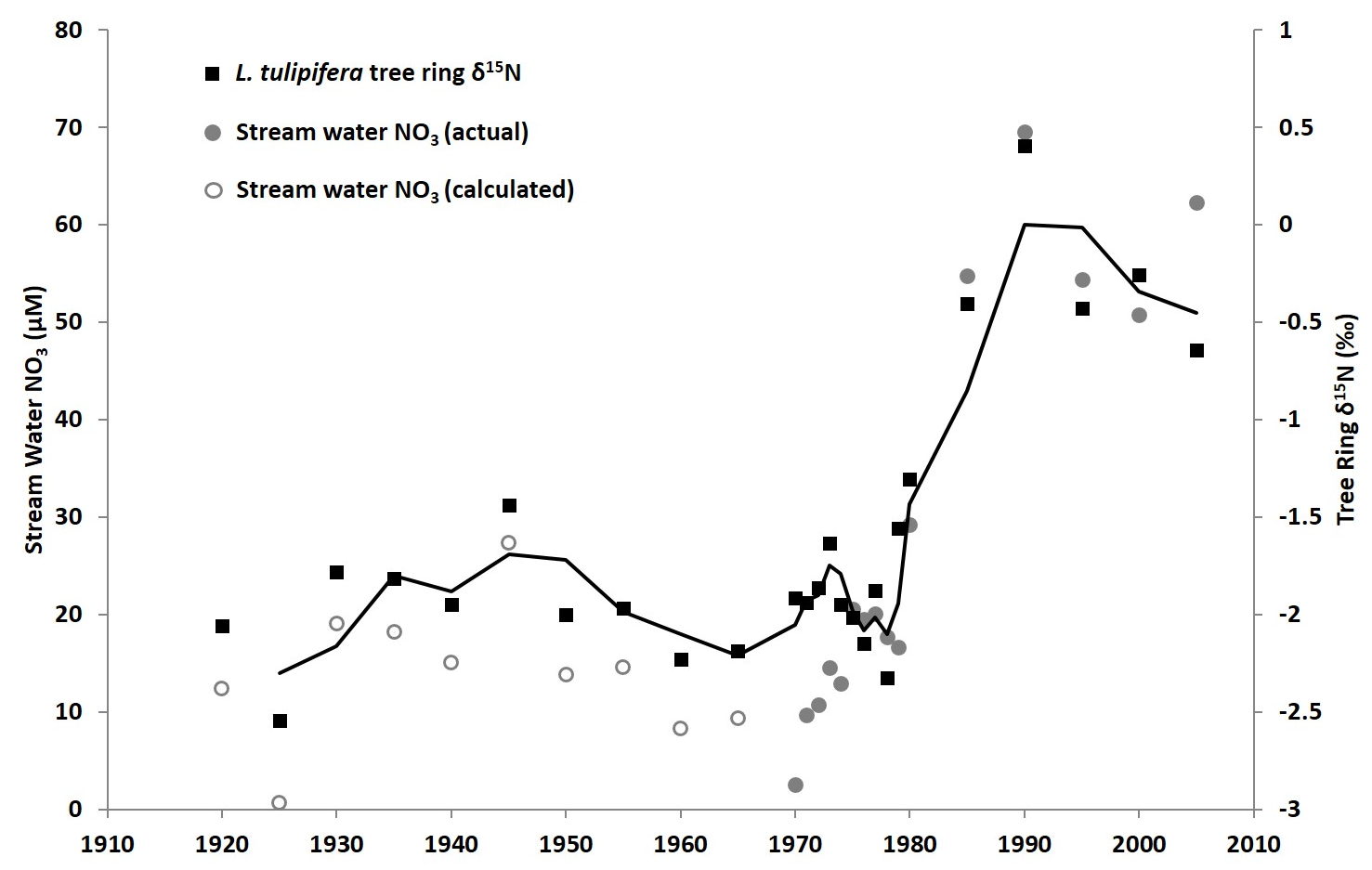

Figure 4-4. L. tulipifera tree ring $\delta^{15} \mathrm{~N}$ and annual mean of monthly flow-weighted stream water $\mathrm{NO}_{3}$ in a long-term reference watershed (WS 4) at the Fernow Experimental Forest. Trend line is a 2-year moving average of L. tulipifera tree ring $\delta^{15} \mathrm{~N}$ to visually depict the long-term trend. Calculated stream water $\mathrm{NO}_{3}$ values (open circles) are based on the linear relationship between tree ring $\delta^{15} \mathrm{~N}$ and stream water $\mathrm{NO}_{3}$ measurements 1970-2005 $(\mathrm{P}<0.001, \mathrm{r}=0.928)$. 


\subsection{References}

Adams MB, Kochenderfer JN, Edwards PJ (2007) The Fernow Watershed Acidification Study: Ecosystem Acidification, Nitrogen Saturation and Base Cation Leaching. Water, Air, Soil Pollut Focus 7:267-273. doi: 10.1007/s11267-006-9062-1

Argerich A, Johnson SL, Sebestyen SD, et al (2013) Trends in stream nitrogen concentrations for forested reference catchments across the USA. Environ Res Lett 8:1-8. doi: 10.1088/1748$9326 / 8 / 1 / 014039$

Barford CC, Montoya JP, Altabet MA, Mitchell R (1999) Steady-state nitrogen isotope effects of $\mathrm{N}_{2}$ and $\mathrm{N}_{2} \mathrm{O}$ production in Paracoccus denitrificans. Appl Evironmental Microbiol 65:989994.

Beghin R, Cherubini P, Battipaglia G, et al (2011) Tree-ring growth and stable isotopes $\left({ }^{13} \mathrm{C}\right.$ and ${ }^{15} \mathrm{~N}$ ) detect effects of wildfires on tree physiological processes in Pinus sylvestris L. Trees 25:627-636. doi: 10.1007/s00468-011-0539-9

Brenneman B, Frederick D, Gardner W, et al (1978) Biomass of species and stands of West Virginia hardwoods. Proc. 2nd Cent. Hardwood For. Conf. West Lafayette, IN, pp 159-178

Bukata AR, Kyser TK (2005) Response of the nitrogen isotopic composition of tree-rings following tree-clearing and land-use change. Environ Sci Technol 39:7777-7783.

Bukata AR, Kyser TK (2007) Carbon and nitrogen isotope variations in tree-rings as records of perturbations in regional carbon and nitrogen cycles. Environ Sci Technol 41:1331-1338.

Bunn AG (2010) Statistical and visual crossdating in R using the dplR library. Dendrochronologia 28:251-258. doi: 10.1016/j.dendro.2009.12.001 
Campbell JL, Hornbeck JW, Mitchell MJ, et al (2004) Input-output budgets of inorganic nitrogen for 24 forest watersheds in the northeastern United States: A review. Water Air Soil Pollut 151:373-396.

Castro M, Peterjohn W, Melillo J, Steudler P (1994) Effects of nitrogen fertilization on the fluxes of $\mathrm{N}_{2} \mathrm{O}, \mathrm{CH}_{4}$, and $\mathrm{CO}_{2}$ from soils in a Florida slash pine plantation. Can J For Res 24:9-13.

Choi W, Lee S, Ro H, et al (2002) Natural $\delta^{15} \mathrm{~N}$ abundances of maize and soil amended with urea and composted pig manure. Plant Soil 245:223-232.

Choi W-J, Lee S-M, Chang SX, Ro H-M (2005) Variations of $\delta^{13} \mathrm{C}$ and $\delta^{15} \mathrm{~N}$ in Pinus densiflora tree-rings and their relationship to environment changes in eastern Korea. Water Air Soil Pollut 164:173-187.

Craine JM, Elmore AJ, Aidar MPM, et al (2009) Global patterns of foliar nitrogen isotopes and their relationships with climate, mycorrhizal fungi, foliar nutrient concentrations, and nitrogen availability. New Phytol 183:980-992. doi: 10.1111/j.1469-8137.2009.02917.x

Elhani S, Lema B, Zeller B, et al (2003) Inter-annual mobility of nitrogen between beech rings: a labelling experiment. Ann For Sci 60:503-508. doi: 10.1051/forest

Elliott EM, Kendall C, Wankel SD, et al (2007) Nitrogen isotopes as indicators of NO(x) source contributions to atmospheric nitrate deposition across the midwestern and northeastern United States. Environ Sci Technol 41:7661-7667.

Falxa-Raymond N, Patterson AE, Schuster WSF, Griffin KL (2012) Oak loss increases foliar nitrogen, $\delta^{15} \mathrm{~N}$ and growth rates of Betula lenta in a northern temperate deciduous forest. Tree Physiol 32:1092-1101. doi: 10.1093/treephys/tps068 
Galloway J, Dentener F, Capone D, et al (2004) Nitrogen cycles: past, present, and future. Biogeochemistry 70:153-226.

Garten C (1993) Variation in foliar ${ }^{15} \mathrm{~N}$ abundance and the availability of soil nitrogen on Walker Branch Watershed. Ecology 74:2098-2113.

Gerhart LM, McLauchlan KK (2014) Reconstructing terrestrial nutrient cycling using stable nitrogen isotopes in wood. Biogeochemistry 120:1-21. doi: 10.1007/s10533-014-9988-8

Gilliam FS, Adams MB (2011) Effects of nitrogen on temporal and spatial patterns of nitrate in streams and soil solution of a central hardwood forest. ISRN Ecol 2011:1-9. doi: $10.5402 / 2011 / 138487$

Gilliam FS, Adams MB, Yurish BM (1996) Ecosystem nutrient responses to chronic nitrogen inputs at Fernow Experimental Forest, West Virginia. Can J For Res 26:196-205.

Gundersen P, Emmett BA, Kjgnaas OJ, et al (1998) Impact of nitrogen deposition on nitrogen cycling in forests: a synthesis of NITREX data. For Ecol Manage 101:37-55.

Hagen-Thorn A, Varnagiryte I, Nihlgård B, Armolaitis K (2006) Autumn nutrient resorption and losses in four deciduous forest tree species. For Ecol Manage 228:33-39. doi: 10.1016/j.foreco.2006.02.021

Härdtle W, Niemeyer T, Fichtner A, et al (2014) Climate imprints on tree-ring $\delta^{15} \mathrm{~N}$ signatures of sessile oak (Quercus petraea Liebl.) on soils with contrasting water availability. Ecol Indic 45:45-50. doi: 10.1016/j.ecolind.2014.03.015

Hart SC, Classen AT (2003) Potential for assessing long-term dynamics in soil nitrogen availability from variations in $\delta^{15} \mathrm{~N}$ of tree rings. Isotopes Environ Health Stud 39:15-28. doi: $10.1080 / 1025601031000102206$ 
Hawkins BJ, Jones MD, Kranabetter JM (2015) Ectomycorrhizae and tree seedling nitrogen nutrition in forest restoration. New For 46:747-771. doi: 10.1007/s11056-015-9488-2

Hietz P, Dünisch O, Wanek W (2010) Long-term trends in nitrogen isotope composition and nitrogen concentration in brazilian rainforest trees suggest changes in nitrogen cycle. Environ Sci Technol 44:1191-1196. doi: 10.1021/es901383g

Hietz P, Turner BL, Wanek W, et al (2011) Long-Term Change in the Nitrogen Cycle of Tropical Forests. Science (80- ) 334:664-666. doi: 10.1126/science.1211979

Hobbie E a, Högberg P (2012) Nitrogen isotopes link mycorrhizal fungi and plants to nitrogen dynamics. New Phytol 196:367-82. doi: 10.1111/j.1469-8137.2012.04300.x

Hobbie J, Hobbie E (2006) ${ }^{15} \mathrm{~N}$ in symbiotic fungi and plants estimates nitrogen and carbon flux rates in arctic tundra. Ecology 87:816-822.

Hogberg P (1997) ${ }^{15} \mathrm{~N}$ natural abundance in soil-plant systems. New Phytol 137:179-203.

Houlton BZ, Sigman DM, Hedin LO (2006) Isotopic evidence for large gaseous nitrogen losses from tropical rainforests. Proc Natl Acad Sci U S A 103:8745-8750. doi: 10.1073/pnas.0510185103

Jung K, Choi W-J, Chang SX, Arshad MA (2013) Soil and tree ring chemistry of Pinus banksiana and Populus tremuloides stands as indicators of changes in atmospheric environments in the oil sands region of Alberta, Canada. Ecol Indic 25:256-265. doi: 10.1016/j.ecolind.2012.10.006

Kalcsits LA, Buschhaus HA, Guy RD (2014) Nitrogen isotope discrimination as an integrated measure of nitrogen fluxes, assimilation and allocation in plants. Physiol Plant 151:293304. doi: $10.1111 / \mathrm{ppl} .12167$ 
Knapp AK, Smith MD, Hobbie SE, et al (2012) Past, present, and future roles of long-term experiments in the LTER network. Bioscience 62:377-389. doi: 10.1525/bio.2012.62.4.9

Kochenderfer JN (2006) Fernow and the Appalachian Hardwood Region. Fernow watershed Acidif. study. Springer, pp 17-39

Li D, Wang X (2008) Nitrogen isotopic signature of soil-released nitric oxide (NO) after fertilizer application. Atmos Environ 42:4747-4754. doi: 10.1016/j.atmosenv.2008.01.042

Likens GE, Buso DC (2012) Dilution and the elusive baseline. Environ Sci Technol 46:43824387. doi: $10.1021 / \mathrm{es} 3000189$

Lilleskov E, Hobbie E, Fahey T (2002) Ectomycorrhizal fungal taxa differing in response to nitrogen deposition also differ in pure culture organic nitrogen use and natural abundance of nitrogen isotopes. New Phytol 154:219-231. doi: DOI 10.1046/j.1469-8137.2002.00367.x

Makarov MI, Onipchenko VG, Malysheva TI, et al (2014) Determinants of ${ }^{15} \mathrm{~N}$ natural abundance in leaves of co-occurring plant species and types within an alpine lichen heath in the Northern Caucasus. Arctic, Antarct Alp Res 46:581-590. doi: 10.1657/1938-424646.3 .581

Mayor J, Bahram M, Henkel T, et al (2015) Ectomycorrhizal impacts on plant nitrogen nutrition: Emerging isotopic patterns, latitudinal variation and hidden mechanisms. Ecol Lett 18:96107. doi: $10.1111 /$ ele. 12377

McLauchlan KK, Craine JM (2012) Species-specific trajectories of nitrogen isotopes in Indiana hardwood forests, USA. Biogeosciences 9:867-874. doi: 10.5194/bgd-8-5935-2011 
McLauchlan KK, Craine JM, Oswald WW, et al (2007) Changes in nitrogen cycling during the past century in a northern hardwood forest. Proc Natl Acad Sci U S A 104:7466-7470. doi: 10.1073/pnas.0701779104

Mizutani H, Hasegawa H, Wada E (1986) High nitrogen isotope ratios for soils of seabird rookeries. Biogeochemistry 2:221-247.

Mizutani H, Wada E (1988) Nitrogen and carbon isotope ratios in seabird rookeries and their ecological implications. Ecology 69:340-349.

Mnich ME, Houlton BZ (2015) Evidence for a uniformly small isotope effect of nitrogen leaching loss: results from disturbed ecosystems in seasonally dry climates. Oecologia 181:323-333. doi: 10.1007/s00442-015-3433-0

Nommik H, Pluth J, Larsson K, Mahendrappa MK (1994) Isotopic fractionation accompanying fertilizer nitrogen transformations in soil and trees of a Scots spine ecosystem. Plant Soil 158:169-182.

Pardo LH, Hemond HF, Montoya JP, et al (2002) Response of the natural abundance of ${ }^{15} \mathrm{~N}$ in forest soils and foliage to high nitrate loss following clear-cutting. Can J For Res 32:11261136. doi: $10.1139 / \mathrm{x} 02-041$

Pardo LH, Nadelhoffer KJ (2012) Using nitrogen isotope ratios to assess terrestrial ecosystems at regional and global scales. In: West JB, Bowen GJ, Dawson TE, Tu KP (eds) Isoscapes. Springer Netherlands, Dordrecht, pp 221-249

Pardo LH, Semaoune P, Schaberg PG, et al (2013) Patterns in $\delta^{15} \mathrm{~N}$ in roots, stems, and leaves of sugar maple and American beech seedlings, saplings, and mature trees. Biogeochemistry 112:275-291. doi: 10.1007/s10533-012-9724-1 
Pardo LH, Templer PH, Goodale CL, et al (2006) Regional assessment of N saturation using foliar and $\operatorname{root} \delta^{15} \mathrm{~N}$. Biogeochemistry 80:143-171. doi: 10.1007/s10533-006-9015-9

Patric J, Smith D (1978) Some effects of urea fertilization on a forested watershed in West Virginia. Proc. 2nd Cent. Hardwood For. Conf. West Lafayette, IN, pp 210-227

Peterjohn WT, Adams MB, Gilliam FS (1996) Symptoms of nitrogen saturation in two central Appalachian hardwood forest ecosystems. Biogeochemistry 35:507-522.

Peterjohn WT, Foster CJ, Christ MJ, Adams MB (1999) Patterns of nitrogen availability within a forested watershed exhibiting symptoms of nitrogen saturation. For Ecol Manage 119:247257. doi: 10.1016/S0378-1127(98)00526-X

Peterjohn WT, McGervey RJ, Sexstone AJ, et al (1998) Nitrous oxide production in two forested watersheds exhibiting symptoms of nitrogen saturation. Can J For Res 28:1723-1732. doi: $10.1139 / \times 98-158$

Read D, Perez-Moreno J (2003) Mycorrhizas and nutrient cycling in ecosystems - a journey towards relevance? New Phytol 157:475-492.

Reinhart K, Eschner A, Trimble G (1963) Effect on streamflow of four forest practices in the mountains of West Virginia.

Robinson D (2001) $\delta^{15} \mathrm{~N}$ as an integrator of the nitrogen cycle. Trends Ecol Evol 16:153-162.

Rose LA, Elliott EM, Adams MB (2015) Triple Nitrate Isotopes Indicate Differing Nitrate Source Contributions to Streams Across a Nitrogen Saturation Gradient. Ecosystems 18:1209-1223. doi: 10.1007/s10021-015-9891-8

Russell KM, Galloway JN, Macko SA, et al (1998) Souces of nitrogen in wet deposition to the Chesapeake Bay region. Atmos Environ 32:2453-2465. 
Saurer M, Cherubini P, Ammann M, et al (2004) First detection of nitrogen from NOx in tree rings: $a^{15} \mathrm{~N} /{ }^{14} \mathrm{~N}$ study near a motorway. Atmos Environ 38:2779-2787. doi: 10.1016/j.atmosenv.2004.02.037

Savard MM, Bégin C, Smirnoff A, et al (2009) Tree-ring nitrogen isotopes reflect anthropogenic NOx emissions and climatic effects. Environ Sci Technol 43:604-9.

Sebilo M, Billen G, Grably M, Mariotti A (2003) Isotopic compsition of nitrate nitrogen as a marker of riparian and benthic denitrificaion at the scale of the whole Seine River system. Biogeochemistry 63:35-51.

Spoelstra J, Schiff SL, Semkin RG, et al (2010) Nitrate attenuation in a small temperate wetland following forest harvest. For Ecol Manage 259:2333-2341. doi: 10.1016/j.foreco.2010.03.006

Stokes M, Smiley T (1996) An introduction to tree-ring dating. The University of Arizona Press, Tucson, AZ

Sun F, Kuang Y, Wen D, et al (2010) Long-term tree growth rate, water use efficiency, and tree ring nitrogen isotope composition of Pinus massoniana $\mathrm{L}$. in response to global climate change and local nitrogen deposition in Southern China. J Soils Sediments 10:1453-1465. doi: $10.1007 / \mathrm{s} 11368-010-0249-8$

Tomlinson G, Siegwolf R, Buchmann N, et al (2014) The mobility of nitrogen across tree-rings of Norway spruce (Picea abies L.) and the effect of extraction method on tree-ring $\delta^{15} \mathrm{~N}$ and $\delta^{13} \mathrm{C}$ values. Rapid Commun Mass Spectrom 28:1-7. doi: 10.1002/rcm.6897 
Treseder KK (2004) A meta-analysis of mycorrhizal responses to nitrogen, phosphorus, and atmospheric $\mathrm{CO}_{2}$ in field studies. New Phytol 164:347-355. doi: 10.1111/j.14698137.2004.01159.x

Trimble G (1977) A history of the Fernow Experimental Forest and the Parsons Timber and Watershed Laboratory.

Venterea RT, Groffman PM, Castro MS, et al (2004) Soil emissions of nitric oxide in two forest watersheds subjected to elevated N inputs. For Ecol Manage 196:335-349. doi: 10.1016/j.foreco.2004.03.028

Vitousek PM, Fahey T, Johnson DW, Swift MJ (1988) Element interactions in forest ecosystems: Succession, allometry and input-output budgets. Biogeochemistry 5:7-34.

Wallenstein M, Peterjohn W, Schlesinger W (2006) N fertilization effects on denitrification and $\mathrm{N}$ cycling in an aggrading forest. Ecol Appl 16:2168-2176.

Wexler SK, Goodale CL, McGuire KJ, et al (2014) Isotopic signals of summer denitrification in a northern hardwood forested catchment. Proc Natl Acad Sci U S A 111:16413-8. doi: $10.1073 /$ pnas. 1404321111

Yoshida $\mathrm{N}(1988){ }^{15} \mathrm{~N}$-depleted $\mathrm{N}_{2} 0$ as a product of nitrification. Nature 335:528-529.

Zeller B, Colin-Belgrand M, Dambrine E, et al (2000) Decomposition of ${ }^{15} \mathrm{~N}$-labelled beech litter and fate of nitrogen derived from litter in a beech forest. Oecologia 123:550-559.

Zhou W, Hu C-S, Li J, et al (2013) Nature ${ }^{15} \mathrm{~N}$ abundance in winter wheat amended with urea and compost: A long-term experiment. Pedosphere 23:835-843. doi: 10.1016/S10020160(13)60075-2 
Chapter 5. Assessing tree ring $\delta^{15} \mathrm{~N}$ of different species as an indicator of $\mathrm{N}$ saturation in a temperate forest using independent long-term records of $\mathbf{N}$ cycling and loss

Formatted for the journal Oecologia 


\subsection{Abstract}

Anthropogenic $\mathrm{N}$ deposition onto forests in the northeastern United States caused varying degrees of $\mathrm{N}$ saturation in the latter part of the $20^{\text {th }}$ century, with potential legacy effects in these forests. However, the scarcity of long-term direct $\mathrm{N}$ cycle measurements complicates the study of the spatial and temporal impact of $\mathrm{N}$ deposition and $\mathrm{N}$ saturation. $\mathrm{N}$ isotopes in tree rings have been used as an indicator of the timing and severity of $\mathrm{N}$ saturation, but there is little verification of this use of $\delta^{15} \mathrm{~N}$. Using independent, long-term records at the Fernow Experimental Forest in Tucker County, WV, we tested the strength of correlation between tree ring $\delta^{15} \mathrm{~N}$ of Liriodendron tulipifera, Quercus rubra, Fagus grandifolia, and Prunus serotina and stream water $\mathrm{NO}_{3}$ loss in a 100 -year-old reference watershed that showed symptoms of $\mathrm{N}$ saturation around 1980. We also measured soil mineralization and nitrification potentials and $\mathrm{NH}_{4}$ and $\mathrm{NO}_{3}$ levels under individual trees and examined the relationship of these variables to the $\delta^{15} \mathrm{~N}$ of recently formed wood. The tree ring $\delta^{15} \mathrm{~N}$ of L. tulipifera and Q. rubra, but not the other two species, was positively correlated with stream water $\mathrm{NO}_{3}$ loss. The tree $\operatorname{ring} \delta^{15} \mathrm{~N}$ of L. tulipifera had a stronger association with stream water $\mathrm{NO}_{3}$ concentration and more closely mirrored an $\mathrm{N}$ saturation signal than Q. rubra, which captured the long-term trend. Soil N pools and transformation rates affected these correlations, and the 2014 tree ring $\delta^{15} \mathrm{~N}$, for the same two species, but not for $P$. serotina or $F$. grandifolia. Thus, two major deciduous tree species, $L$. tulipifera and Q. rubra, were able to record N saturation, but with different sensitivities. The surrounding stand dynamics and mobility of $\mathrm{N}$ within trees may impede the ability of $F$. grandifolia and P. serotina to record N saturation signals. Overall, there is enough response of tree ring $\delta^{15} \mathrm{~N}$ to $\mathrm{N}$ cycling to have some utility, but there is enough variability to preclude its 
widespread application until more is known about the mechanisms that govern wood $\delta^{15} \mathrm{~N}$ variation.

\subsection{Introduction}

Forests in the northeastern United States experienced high deposition of reactive nitrogen $(\mathrm{N})$ over the last half-century (Galloway et al. 2004). Since primary production in these ecosystems is often $\mathrm{N}$-limited, the retention of $\mathrm{N}$ in forests is typically high and supply is low relative to demand (a "closed" $\mathrm{N}$ cycle). However, high inputs of $\mathrm{N}$ from atmospheric deposition can cause the supply of $\mathrm{N}$ to exceed the biotic demand in forest stands, creating a more "open" ecosystem $\mathrm{N}$ cycle - a phenomenon termed $\mathrm{N}$ saturation. Forests saturated with $\mathrm{N}$ have high rates of $\mathrm{N}$ mineralization and nitrification, and elevated losses of mobile $\mathrm{NO}_{3}$ in stream water (Aber et al. 1998; Lovett and Goodale 2011). There is evidence of $\mathrm{N}$ saturation in the northeastern United States (Edwards and Helvey 1991; Peterjohn et al. 1996; Aber et al. 1998), with possible longterm impacts including the loss of important base cations and changes in understory and overstory species composition (Edwards and Helvey 1991; Gilliam et al. 1996, 2016; May et al. 2005). However, few long-term records of changes in $\mathrm{N}$ cycling exist, complicating rigorous assessment of the legacy effects of $\mathrm{N}$ deposition. In the absence of direct records, there is the need for a well-established, long-term proxy of $\mathrm{N}$ cycling.

The $\delta^{15} \mathrm{~N}$ signature of plant tissue could potentially serve as such an index of the status of the $\mathrm{N}$ cycle in a forest stand (Robinson 2001; Pardo et al. 2006; Pardo and Nadelhoffer 2012). N assimilated by plants and incorporated into tissue should have a similar isotopic signature as the 
soil $\mathrm{N}$ pool from which it was acquired. In the $\mathrm{N}$ cycle of a temperate forest, the primary fractionating step in well-drained soils with little denitrification is microbial nitrification, a process that preferentially uses the lighter ${ }^{14} \mathrm{~N}$ isotope, and that results in a ${ }^{15} \mathrm{~N}$-enriched $\mathrm{NH}_{4}$ substrate pool and a ${ }^{15} \mathrm{~N}$-depleted $\mathrm{NO}_{3}$ product pool. As an anion, $\mathrm{NO}_{3}$ is readily leached into stream water, while $\mathrm{NH}_{4}$ remains associated with cation exchange sites in the soil. So, when $\mathrm{N}$ deposition causes an increase in nitrification, more ${ }^{14} \mathrm{NO}_{3}$ is leached from the plant available $\mathrm{N}$ pool, resulting in a shift towards higher ${ }^{15} \mathrm{~N}$ abundance under more "open" $\mathrm{N}$ cycling. Although plants acquire $\mathrm{N}$ as both $\mathrm{NH}_{4}$ and $\mathrm{NO}_{3}$, over time, the loss of ${ }^{15} \mathrm{~N}$-depleted $\mathrm{NO}_{3}$ increases the overall $\delta^{15} \mathrm{~N}$ of $\mathrm{N}$ retained in the system. Since the $\delta^{15} \mathrm{~N}$ signature of plant tissue reflects the plant available $\mathrm{N}$ pool, it would shift accordingly when the supply of $\mathrm{N}$ into the system exceeds $\mathrm{N}$ demand, and could be used as a proxy for reduced $\mathrm{N}$ retention in the absence of direct measurements.

The $\delta^{15} \mathrm{~N}$ signature of tree rings may be particularly useful as a long-term indicator of changes in $\mathrm{N}$ cycling (Gerhart and McLauchlan 2014). Forest ecosystems are prevalent in areas that experience the highest deposition of $\mathrm{N}$ on land, and the annual preservation of environmental changes in tree rings potentially make them a powerful tool for studying temporal changes in the $\mathrm{N}$ cycle. Indeed, wood $\delta^{15} \mathrm{~N}$ has been used to evaluate the effects of disturbance (Falxa-Raymond et al. 2012) and pollution (Savard et al. 2009) on the $\mathrm{N}$ cycle at specific sites. At the regional and continental scale, it appears to document changes in $\mathrm{N}$ cycling in response to various anthropogenic influences, such as $\mathrm{N}$ deposition, increasing $\mathrm{CO}_{2}$, and changing climate (Elmore et al. 2016; McLauchlan et al. 2017). Despite its frequent use and theoretical basis (Robinson 2001), there is little rigorous verification of how well tree ring $\delta^{15} \mathrm{~N}$ signatures preserve changes 
in the local $\mathrm{N}$ cycle. Tracer studies show that tree rings can preserve large isotopic changes in $\mathrm{N}$ source pools (Hart and Classen 2003), and the tree ring $\delta^{15} \mathrm{~N}$ of some species also responds to application of fertilizers (Elhani et al. 2005; Burnham et al. 2016). However, tracer and fertilizer additions have a sudden, large impact on the $\delta^{15} \mathrm{~N}$ of plant available $\mathrm{N}$ pools, while enhanced atmospheric $\mathrm{N}$ deposition should have slower, subtler effects. Consequently, tracer and fertilizer studies may not accurately approximate how long-term $\mathrm{N}$ deposition and the associated changes in the $\mathrm{N}$ cycle are recorded in the $\delta^{15} \mathrm{~N}$ of tree rings.

Although tree ring $\delta^{15} \mathrm{~N}$ should reflect $\mathrm{N}$-saturation caused by long-term deposition, a variety of other factors could also impact the tree ring $\delta^{15} \mathrm{~N}$ record. One such factor is the $\delta^{15} \mathrm{~N}$ signature of $\mathrm{N}$ deposition that could affect the $\delta^{15} \mathrm{~N}$ of the plant available $\mathrm{N}$ pool and shift through time with changes in emission rates and sources (Elliott et al. 2007). Even if the deposition signature was stable, another complicating factor is gaseous $\mathrm{N}$ losses which strongly fractionate $\mathrm{N}$ isotope pools and could overwhelm any effect of ${ }^{15} \mathrm{~N}$ loss in stream water $\mathrm{NO}_{3}$ (Mnich and Houlton 2015). Furthermore, gaseous $\mathrm{N}$ losses are spatially and temporally variable, and highly dependent on soil moisture and weather conditions (Firestone and Davidson 1989; Weier et al. 1993; Wallenstein et al. 2006; Wexler et al. 2014). Spatial patterns of soil $\mathrm{N}$ availability, such as $\mathrm{C}: \mathrm{N}$ ratio, net mineralization and nitrification rates, and tissue $\mathrm{N}$ content are also related to wood, root, and foliar $\delta^{15} \mathrm{~N}$ (Garten 1993; Pardo et al. 2006; Templer et al. 2007; Smith et al. 2016). As a result, trees at different positions within a single watershed vary in their ability to integrate and record the overall ecosystem $\mathrm{N}$ cycle. Trees at lower elevations in a watershed tend to grow in locations that are more hydrologically connected to stream water and the isotopic record in their tissues is more likely to reflect changes in stream water $\mathrm{NO}_{3}$ losses, while the isotopic signal in 
higher elevation trees should more closely reflect gaseous N losses (Garten 1993). Even if the tree ring $\delta{ }^{15} \mathrm{~N}$ signal reflects the effect of $\mathrm{N}$ saturation and stream $\mathrm{NO}_{3}$ loss, the stability of the record as the tree ages has been questioned, due to the potential for $\mathrm{N}$ compounds in tree rings to be mobile (Elhani et al. 2003; Hart and Classen 2003). Finally, the form of $\mathrm{N}$ in tree rings is unknown, as are the biochemical mechanisms of $\mathrm{N}$ incorporation into woody tissue, which may be isotopically fractionating processes. Thus, it is far from established that tree ring $\delta^{15} \mathrm{~N}$ effectively records and preserves the $\mathrm{N}$ status of ecosystems through time.

Given this uncertainty, we used a significant change in the 30-year record of stream-water nitrate concentration for a small watershed at the Fernow Experimental Forest (FEF) to test the utility of tree ring $\delta^{15} \mathrm{~N}$ as a proxy of changes in N cycling. Watershed 4 (WS 4) at the FEF has one of the longest continuous stream water $\mathrm{NO}_{3}$ records in the eastern United States, and a $145 \%$ increase in stream water $\mathrm{NO}_{3}$ occurred around 1980 , which is thought to be a symptom of $\mathrm{N}$ saturation from elevated atmospheric $\mathrm{N}$ inputs (Peterjohn et al. 1996). Thus, if changes in tree ring $\delta^{15} \mathrm{~N}$ accurately reflect changes in stand $\mathrm{N}$ dynamics, then the increased nitrate loss should be preserved in the chronology of tree ring $\delta^{15} \mathrm{~N}$ recorded by the dominant tree species. Furthermore, since nitrification is a key N-fractionating step in well-drained temperate forest soils, we also expect that the relationship between tree ring $\delta^{15} \mathrm{~N}$ and stream water $\mathrm{NO}_{3}$ would be stronger in portions of the watershed with higher nitrification and extractable $\mathrm{NO}_{3}$ pools, and that the $\delta^{15} \mathrm{~N}$ in the recently formed wood of a given tree should be positively related to the rate of nitrification in the surrounding soil. 


\subsection{Methods}

The FEF is a US Forest Service research site located in Tucker County, WV, USA (39 $03^{\prime} 15^{\prime \prime}$ $\mathrm{N}, 79^{\circ} 49^{\prime} 15^{\prime \prime} \mathrm{W}$ ). Watershed 4 (WS $4,38.7 \mathrm{ha}$ ) is a long-term reference watershed, last commercially logged circa 1910 and allowed to naturally regrow since that time. The predominant soil is a Calvin channery silt loam (loamy-skeletal, mixed, mesic Typic Dystrochrept), elevation ranges from approximately 760 to $840 \mathrm{~m}$, and the slope averages $16 \%$ at a southeasterly aspect (Kochenderfer 2006). Nearly continuous hydrologic and biogeochemical measurements in the watershed include stream flow and precipitation since 1951 and 1952, stream chemistry including $\mathrm{N}$ export since 1970, and bulk $\mathrm{N}$ deposition (wet + particulate) since 1983. Annually, FEF WS 4 receives an average of $\sim 145 \mathrm{~cm}$ of rainfall. The forest is a stand of mixed hardwood species consisting of Acer saccharum (21.9\% of stems), Acer rubrum (21.1\%), Quercus rubra (16.6\%), Prunus serotina (6.0\%), Quercus prinus (5.2\%), Liriodendron tulipifera (4.8\%), and Fagus grandifolia (4.0\%).

During July, 2014, we collected increment cores from four major tree species within FEF WS 4 (seven individual trees per species): Q. rubra, P. serotina, L. tulipifera, and F. grandifolia (Figure 5-1). These represent both arbuscular mycorrhizal (P. serotina and L. tulipifera) and ectomycorrhizal (Q. rubra and F. grandifolia) species. We chose mature, canopy trees of each species $>40 \mathrm{~cm}$ in diameter at breast height (DBH), except for one somewhat smaller $F$. grandifolia tree $(32 \mathrm{~cm} \mathrm{DBH})$. Since each species is not evenly distributed across the watershed, we opportunistically selected trees that were near (within $\sim 25 \mathrm{~m}$ ) trees from the other species being examined in order to minimize species differences in $\delta^{15} \mathrm{~N}$ due to their spatial location and elevation (Garten 1993). We collected two increment cores from each tree, one from either side 
of the tree parallel to the contour of the land, using 5-mm diameter increment borers (Mora of Sweden, Mora, Sweden). Increment corers were rinsed with deionized water between trees, and the cores were air dried prior to processing for ring width and wood $\delta^{15} \mathrm{~N}$. One core from each tree was mounted and sanded to better visualize the annual growth rings. The ring widths were measured and cores were cross-dated, using the dplR package for R to assess cross-dating accuracy (Bunn 2010). The second core from each tree was used for $\delta^{15} \mathrm{~N}$ analysis. These cores were cut into three-year segments from 1971 through 2000, and each segment was ground into a fine powder using a dental amalgamator (Henry Schein, Inc., Melville, NY), and 8-10 mg of tissue from each were wrapped in tin capsules. The $\delta^{15} \mathrm{~N}$ of each segment was measured via isotope ratio gas chromatography-mass spectrometry by the Central Appalachians Stable Isotope Facility at the University of Maryland Center for Environmental Science Appalachian Laboratory (Frostburg, MD).

To determine if the rates of soil $\mathrm{N}$ transformations are related to tree ring $\delta^{15} \mathrm{~N}$, we collected mineral soils from under each cored tree in July of 2014. The area of the vertically projected canopy under each tree was divided into four quadrants, and two soil cores were extracted from each quadrant, within $\sim 3 \mathrm{~m}$ of the trunk, using a 2.2-cm inner diameter soil-recovery probe (AMS, Inc., American Falls, ID, USA). The top 5-cm of mineral soil from the soil cores were pooled into one sample for each tree. Prior to sieving, the soils were weighed to calculate dry mass (using the gravimetric water content) and bulk density. The soils were then sieved to pass through a 5.6-mm (\#3.5) mesh testing sieve. A subsample of soil was used for gravimetric determination of moisture content, in which 5-6 g of soil were weighed before and after drying for 48 hours at $65^{\circ} \mathrm{C}$. 
We measured net mineralization, ammonification, and nitrification potentials in the collected soils using a lab incubation. One $\sim 10 \mathrm{~g}$ subsample of soil was incubated in the dark at room temperature for $5 \mathrm{~d}$ to account for any collection disturbance spike in $\mathrm{N}$ transformation rates, and a second subsample was incubated for an additional $28 \mathrm{~d}$ to measure the rate of $\mathrm{NH}_{4}$ and $\mathrm{NO}_{3}$ production in the soil. Both were extracted in $1 \mathrm{M} \mathrm{KCl}$ by gently shaking for 30 minutes, filtering through a polyethersulfone filter with $0.45 \mu \mathrm{M}$ pore size (Supor membrane, Pall Life Sciences, Ann Arbor, MI, USA), and storing at $-20^{\circ} \mathrm{C}$ until $\mathrm{NO}_{3}$ and $\mathrm{NH}_{4}$ analyses were performed using a Lachat QuikChem 8500 Series 2 Auto-analyzer (QuikChem Methods 12-107-04-1-B and 12107-06-2-A).

\section{Statistical analyses}

To reduce the between-tree variability, and focus on the long-term temporal trend in tree ring $\delta^{15} \mathrm{~N}$, we standardized the isotope values of 3-year time segments by subtracting the within-tree mean wood $\delta^{15} \mathrm{~N}$ (Gerhart and McLauchlan 2014; Burnham et al. 2016). The 7 replicate trees for each species were then averaged within each 3-year time segment. We used a Pearson correlation analysis to measure the strength and significance $(\alpha=0.05)$ of the relationship between average standardized tree ring $\delta^{15} \mathrm{~N}$ and the monthly flow-weighted average stream water $\mathrm{NO}_{3}$ concentration through time for each species. We then generated Pearson's correlation coefficients (r) for the relationships between each individual tree's standardized $\delta^{15} \mathrm{~N}$ and WS 4 stream water $\mathrm{NO}_{3}$ concentration through time. These r-values were Fisher transformed and used as dependent variables in a 1-way ANOVA with Tukey's HSD post-hoc analysis to determine if 
the strength of the correlation between tree ring $\delta^{15} \mathrm{~N}$ and stream water $\mathrm{NO}_{3}$ concentration differed between tree species.

We used multiple linear regressions to test if current inorganic soil $\mathrm{N}$ pools or soil $\mathrm{N}$ transformation rates could predict either the temporal trend in tree ring $\delta^{15} \mathrm{~N}$ or tree ring $\delta^{15} \mathrm{~N}$ of the most recent wood (2014). We ran one regression with a dependent variable of tree-specific correlation coefficient between tree ring $\delta^{15} \mathrm{~N}$ and stream water $\mathrm{NO}_{3}$ and independent variables of soil potential net mineralization, potential net nitrification, the percent of mineralized $\mathrm{N}$ nitrified to $\mathrm{NO}_{3}$ (percent nitrification), extractable $\mathrm{NH}_{4}$, and extractable $\mathrm{NO}_{3}$ pools. In a second regression, we used the $\delta^{15} \mathrm{~N}$ of the 2014 tree ring as the dependent variable, and the same $\mathrm{N}$ transformation and extractable pool independent variables. Due to the nature of the predictor variables examined, we assessed multicollinearity using variance inflation factors (VIF values). To adhere to the assumption of independence of predictors as best as possible we excluded those variables from the regression model that had VIF values of $>5$. In our final models, the VIF values were all $<1.5$. All statistical analyses were completed using Minitab 17 statistical software (Minitab, Inc., State College, PA, USA).

\subsection{Results}

The mean of the monthly flow weighted stream water $\mathrm{NO}_{3}$ concentration in FEF WS 4 increased from $\sim 12 \mu \mathrm{M}$ in the early $1970 \mathrm{~s}$ to $\sim 50 \mu \mathrm{M}$ in the early $1980 \mathrm{~s}$, and it has remained around that level since (Figure 5-2). Within tree species, the average $Q$. rubra $(\mathrm{r}=0.81, \mathrm{P}=0.004)$ and $L$. tulipifera $(\mathrm{r}=0.91, \mathrm{P}<0.001)$ standardized tree $\operatorname{ring} \delta^{15} \mathrm{~N}$ were positively correlated with stream 
water $\mathrm{NO}_{3}$ concentration, but significant correlations were not found for $P$. serotina $(\mathrm{P}=0.46)$ nor $F$. grandifolia $(\mathrm{P}=0.44)$. The temporal dynamics found in stream water $\mathrm{NO}_{3}$ concentrations were fairly well characterized by the temporal changes in the standardized tree ring $\delta^{15} \mathrm{~N}$ of $L$. tulipifera. Over the $\sim 10$-year period from $1977-79$ until 1986-88, L. tulipifera standardized tree ring $\delta^{15} \mathrm{~N}$ increased from $-2.2 \%$ to $1.2 \%$ ( $\left(+3 \%\right.$ ). While the temporal pattern found in the $\delta^{15} \mathrm{~N}$ record of $Q$. rubra tree rings captured the overall trend in stream water $\mathrm{NO}_{3}$ concentrations, it was less sensitive to the abruptness of change than the record contained in the rings of $L$. tulipifera. The standardized tree ring $\delta^{15} \mathrm{~N}$ of $Q$. rubra increased from $-0.39 \%$ to $0.06 \%$ (+0.45\%o) from $1971-73$ through $1980-82$, and later increased to $0.23 \%$ in $1989-91$ and $0.31 \%$ in 1998-2000 (Figure 5-2).

The average net mineralization and nitrification potentials under the tree canopies were $1.02 \mu \mathrm{g}$ $\mathrm{N} \mathrm{g}^{-1}$ dry soil day ${ }^{-1}$ and $1.01 \mu \mathrm{g} \mathrm{g}^{-1}$ dry soil day ${ }^{-1}$, respectively, and they did not significantly differ between species (Table 5-1). The net nitrification potential was $96.7 \%$ of the net mineralization potential rate, and this, as well as extractable soil $\mathrm{NO}_{3}$ levels, also did not differ between species. However, the extractable $\mathrm{NH}_{4}$ pool was different between species $(\mathrm{F}=6.45, \mathrm{P}$ $=0.002)$, with more extractable $\mathrm{NH}_{4}$ present in soils under $P$. serotina and $Q$. rubra trees $(6.1$ and $5.2 \mu \mathrm{g} \mathrm{N} \mathrm{g}^{-1}$ dry soil, respectively) than under L. tulipifera $(2.0 \mu \mathrm{g} \mathrm{N} \mathrm{g}$ dry soil). Soils under $F$. grandifolia had intermediate levels of extractable $\mathrm{NH}_{4}\left(2.9 \mu \mathrm{g} \mathrm{N} \mathrm{g}^{-1}\right.$ dry soil) (Table 51). 
Linear regression showed that some current soil $\mathrm{N}$ cycle rates and pools were significant predictors of correlations between L. tulipifera individual tree $\delta^{15} \mathrm{~N}$ and stream water $\mathrm{NO}_{3}$ concentration through time, but they were not predictors for the other species. More specifically, a weaker correlation between stream water $\mathrm{NO}_{3}$ concentration and L. tulipifera tree ring $\delta^{15} \mathrm{~N}$ was associated with higher net mineralization potential $(t=-3.40, P=0.027)$, but a stronger correlation was associated with higher extractable soil $\mathrm{NO}_{3}(\mathrm{t}=3.06, \mathrm{P}=0.038)$. For the most recently formed wood, and across all species examined, only higher soil $\mathrm{NO}_{3}$ was associated with higher tree ring $\delta^{15} \mathrm{~N}\left(\mathrm{R}^{2}=18.3 \%, \mathrm{~F}=5.38, \mathrm{P}=0.029\right)$ (Figure 5-3). However, stronger effects were detected for individual species. For L. tulipifera trees, extractable soil $\mathrm{NH}_{4}$ was negatively associated with the 2014 tree $\operatorname{ring} \delta^{15} \mathrm{~N}\left(\mathrm{R}^{2}=59.9 \%, \mathrm{~F}=7.45, \mathrm{P}=0.041\right)$. For $Q$. rubra, the 2014 tree ring $\delta^{15} \mathrm{~N}$ was positively associated with the aerial net nitrification potential $\left(\mathrm{R}^{2}=79.7 \%, \mathrm{~F}=19.6, \mathrm{P}=0.007\right)$. And there were no soil $\mathrm{N}$ pool or transformation rate variables that were significantly associated with the 2014 tree ring $\delta^{15} \mathrm{~N}$ of P. serotina or F. grandifolia.

\subsection{Discussion}

Of the four species we examined, the tree ring $\delta^{15} \mathrm{~N}$ of L. tulipifera and Q. rubra was positively correlated with direct measurements of stream water $\mathrm{NO}_{3}$ concentration in FEF WS 4. The similarity between the tree ring $\delta^{15} \mathrm{~N}$ of L. tulipifera and the temporal pattern in stream water $\mathrm{NO}_{3}$ concentration was particularly striking. The $3 \%$ increase in $\delta^{15} \mathrm{~N}$ coincided with a $38 \mu \mathrm{M}$ increase (317\%) in stream water $\mathrm{NO}_{3}$ that has been attributed to $\mathrm{N}$ saturation under long-term anthropogenic deposition (Peterjohn et al. 1996). In contrast, although the tree ring $\delta^{15} \mathrm{~N}$ of $Q$. rubra reflected the overall trend in stream $\mathrm{NO}_{3}$ concentrations, it appears to be less sensitive to shorter-term dynamics. Among all species, trees that were in areas of higher $\mathrm{NO}_{3}$ availability 
were stronger recorders of stream water $\mathrm{NO}_{3}$ through time, and this effect was particularly strong for L. tulipifera. This was expected, because areas of high $\mathrm{NO}_{3}$ availability are likely to contribute more $\mathrm{NO}_{3}$ to stream water via leaching, and so the isotopic effect on the plant available N pool should be strongest here (Pardo and Nadelhoffer 2012). Likewise, areas of higher $\mathrm{NO}_{3}$ in the soil had higher $\delta^{15} \mathrm{~N}$ in the most recently formed wood, and within $Q$. rubra trees, a higher potential for $\mathrm{NO}_{3}$ production in the soil was associated with higher tree ring $\delta^{15} \mathrm{~N}$. These effects all support tree ring $\delta^{15} \mathrm{~N}$ as an indicator of the effects of $\mathrm{N}$ saturation, at least for two important deciduous tree species. Furthermore, they suggest that measurements of soil $\mathrm{NO}_{3}$ pools may be useful in selecting the individual trees whose tree ring $\delta^{15} \mathrm{~N}$ has the greatest potential to record changes in leaching losses of $\mathrm{NO}_{3}$.

The negative association between soil $\mathrm{NH}_{4}$ and tree ring $\delta^{15} \mathrm{~N}$ for $L$. tulipifera, and between net mineralization and the strength of correlation between L. tulipifera tree ring $\delta^{15} \mathrm{~N}$ and stream $\mathrm{NO}_{3}$ loss through time, may hold important implications for the use of this species as an indicator of $\mathrm{N}$ cycling. Burnham et al. (2016) found that the tree ring $\delta^{15} \mathrm{~N}$ of this species did not respond to a whole-watershed urea fertilization event in FEF WS 1, but did respond to a later increase in baseline stream water $\mathrm{NO}_{3}$ that coincided with the one observed in the WS 4 stream water record. Urea is a form of organic $\mathrm{N}$ fertilizer that is quickly converted to $\mathrm{NH}_{4}$ in the soil (Lloyd and Sheaffe 1973). Indeed, after the urea fertilization of WS 1, Patric and Smith (1978) reported an ammonia odor, indicating a high availability of $\mathrm{NH}_{4}$ and volatilization of $\mathrm{NH}_{3}$. Given the results of this study it appears that the high $\mathrm{NH}_{4}$ availability following the addition of urea may have decreased the sensitivity of L. tulipifera to changes in $\mathrm{N}$ loss, explaining the lack of response of that species' tree ring $\delta^{15} \mathrm{~N}$ to the urea treatment. Thus, the type of $\mathrm{N}$ addition could 
inhibit the ability of this species to effectively record the disturbance in the $\mathrm{N}$ cycle. While the mechanism through which this might occur is unknown, this potential effect illustrates that different species may be appropriate for measuring different $\mathrm{N}$ cycle changes.

While $Q$. rubra tree ring $\delta^{15} \mathrm{~N}$ was positively correlated with stream water $\mathrm{NO}_{3}$, it appeared to better capture the long-term trend in stream $\mathrm{NO}_{3}$ concentration (Figure 5-4), rather than the shorter-term dynamics. This could be due to some mobility of $\mathrm{N}$ compounds between the rings of this species after the wood is formed. There is evidence of the movement of $\mathrm{N}$ compounds between rings after ring formation in Q. rubra (Burnham et al. 2016) and in other species (Elhani et al. 2003; Hart and Classen 2003). Inter-annual mobility of $\mathrm{N}$ would smooth out the preserved signal of any response of tree ring $\delta^{15} \mathrm{~N}$ to a perturbation in the $\mathrm{N}$ cycle and result in the observed response of Q. rubra to long-term N cycle changes in WS 4. Although this species does not capture abrupt, short-term dynamics as precisely as L. tulipifera in this study, it appears to more consistently respond to both perturbations in the $\mathrm{N}$ cycle from a large urea addition (Burnham et al. 2016) and the long-term effects of $\mathrm{N}$ deposition.

It was also notable that two species, $P$. serotina and $F$. grandifolia, showed no relationship between tree ring $\delta^{15} \mathrm{~N}$ and stream water $\mathrm{NO}_{3}$ in WS 4 , nor between any soil $\mathrm{N}$ pools or transformation rates and $\delta^{15} \mathrm{~N}$ of newly formed woody tissue. It is unclear why P. serotina tree ring $\delta^{15} \mathrm{~N}$ did not respond to changes in watershed $\mathrm{N}$ cycling, particularly since it did respond to urea fertilization in a nearby watershed (Burnham et al. 2016). For F. grandifolia, there is some evidence of mobility of $\mathrm{N}$ within the woody tissue of this species (Elhani et al. 2003). This 
species may also be an ineffective recorder of the $\mathrm{N}$ saturation signal because it can be more responsive to surrounding stand dynamics and changes in the light environment than patterns of long-term $\mathrm{N}$ deposition. Indeed, we observed that individual $F$. grandifolia trees would often exhibit short-term increases in BAI that did not coincide with other $F$. grandifolia trees in the same watershed. This pattern we attribute to the fact that, in WS $4, F$. grandifolia is common in the sub-canopy, where it grows slowly until the canopy is disturbed. This is consistent with the fact that the annual coefficient of variation in F. grandifolia BAI ( $85 \%$ across all years) was much higher than the values for the other species (all $\sim 50 \%$ or lower). Further evidence was also seen in the concurrent growth response of four $F$. grandifolia trees in a nearby watershed when it was harvested in the late 1950s (Burnham et al. 2016). As a result, we suspect that the short-term increases in F. grandifolia $\mathrm{N}$ demand during periods of rapid growth hindered this species' ability to integrate long-term changes in N supply and demand within WS 4.

Although tree ring $\delta^{15} \mathrm{~N}$ shows promise as an indicator of $\mathrm{N}$-saturation, uncertainty remains regarding its effective implementation on both a broad and local scale. There are species differences in how strongly tree ring $\delta^{15} \mathrm{~N}$ indicates changes in $\mathrm{N}$ cycling through time, and spatial heterogeneity in $\mathrm{N}$ saturation effects, even within a given locale, can mask the effects of ecosystem $\mathrm{N}$ supply and demand on tree ring $\delta^{15} \mathrm{~N}$. These factors likely cause the high variability in tree ring and other plant tissue $\delta^{15} \mathrm{~N}$ found in broad-scale studies (Craine et al. 2009; McLauchlan et al. 2017), and our current knowledge of the biochemistry of $\mathrm{N}$ in wood and species-by-species $\mathrm{N}$ physiology prevents us from fully understanding the mechanisms that govern the tree ring $\delta^{15} \mathrm{~N}$ signal. However, despite the uncertainty and high variability, large data sets can reveal coherent signals that are consistent with broad patterns of change in $\mathrm{N}$ retention 
(Hietz et al. 2011; McLauchlan and Craine 2012; Gerhart and McLauchlan 2014; McLauchlan et al. 2017). At the more local level, the results of this study suggest that using measurements of current $\mathrm{N}$ pools and transformation rates may help inform which trees and species to select for tree ring $\delta^{15} \mathrm{~N}$ analysis. Overall, our results indicate that there is enough response of tree ring $\delta^{15} \mathrm{~N}$ to $\mathrm{N}$ cycling to have some utility, but there is enough variability to preclude its widespread application until more is known about the mechanisms that govern wood $\delta^{15} \mathrm{~N}$ variation. 


\subsection{Tables and Figures}

Table 5-1. Mean KCl-extractable soil $\mathrm{N}$ pools and transformation rates $(\mathrm{NMP}=$ net mineralization potential, NNP = net nitrification potential) under the canopies of each tree species. Means that do not share a letter are significantly different $(\mathrm{P}<0.05)$.

\begin{tabular}{lcccccc}
\hline \hline & & $\begin{array}{c}\mathrm{NH}_{4} \\
\left(\mu \mathrm{g} \mathrm{g}^{-1} \text { soil }\right)\end{array}$ & $\begin{array}{c}\mathrm{NO}_{3} \\
\left(\mu \mathrm{g} \mathrm{N} \mathrm{g}^{-1} \text { soil }\right)\end{array}$ & $\begin{array}{c}\mathrm{NMP} \\
\left(\mu \mathrm{g} \mathrm{g} \mathrm{g}^{-1} \text { soil day }^{-1}\right)\end{array}$ & $\begin{array}{c}\mathrm{NNP} \\
\left(\mu \mathrm{g} \mathrm{g}^{-1} \text { soil day }^{-1}\right)\end{array}$ & $\begin{array}{c}\% \\
\text { nitrification }\end{array}$ \\
\hline P. serotina & 7 & $6.1^{\mathrm{a}}(1.0)$ & $7.7^{\mathrm{a}}(1.9)$ & $1.00^{\mathrm{a}}(0.19)$ & $1.10^{\mathrm{a}}(0.15)$ & $117.6^{\mathrm{a}}(9.8)$ \\
Q. rubra & 7 & $5.2^{\mathrm{ab}}(0.8)$ & $6.2^{\mathrm{a}}(1.8)$ & $1.05^{\mathrm{a}}(0.20)$ & $0.99^{\mathrm{a}}(0.24)$ & $83.2^{\mathrm{a}}(12.7)$ \\
F. grandifolia & 7 & $2.9^{\mathrm{bc}}(0.7)$ & $7.8^{\mathrm{a}}(2.0)$ & $0.95^{\mathrm{a}}(0.14)$ & $0.95^{\mathrm{a}}(0.16)$ & $97.3^{\mathrm{a}}(6.6)$ \\
L. tulipifera & 7 & $2.0^{\mathrm{c}}(0.4)$ & $8.9^{\mathrm{a}}(1.7)$ & $1.09^{\mathrm{a}}(0.16)$ & $1.01^{\mathrm{a}}(0.18)$ & $88.5^{\mathrm{a}}(10.2)$ \\
\hline
\end{tabular}




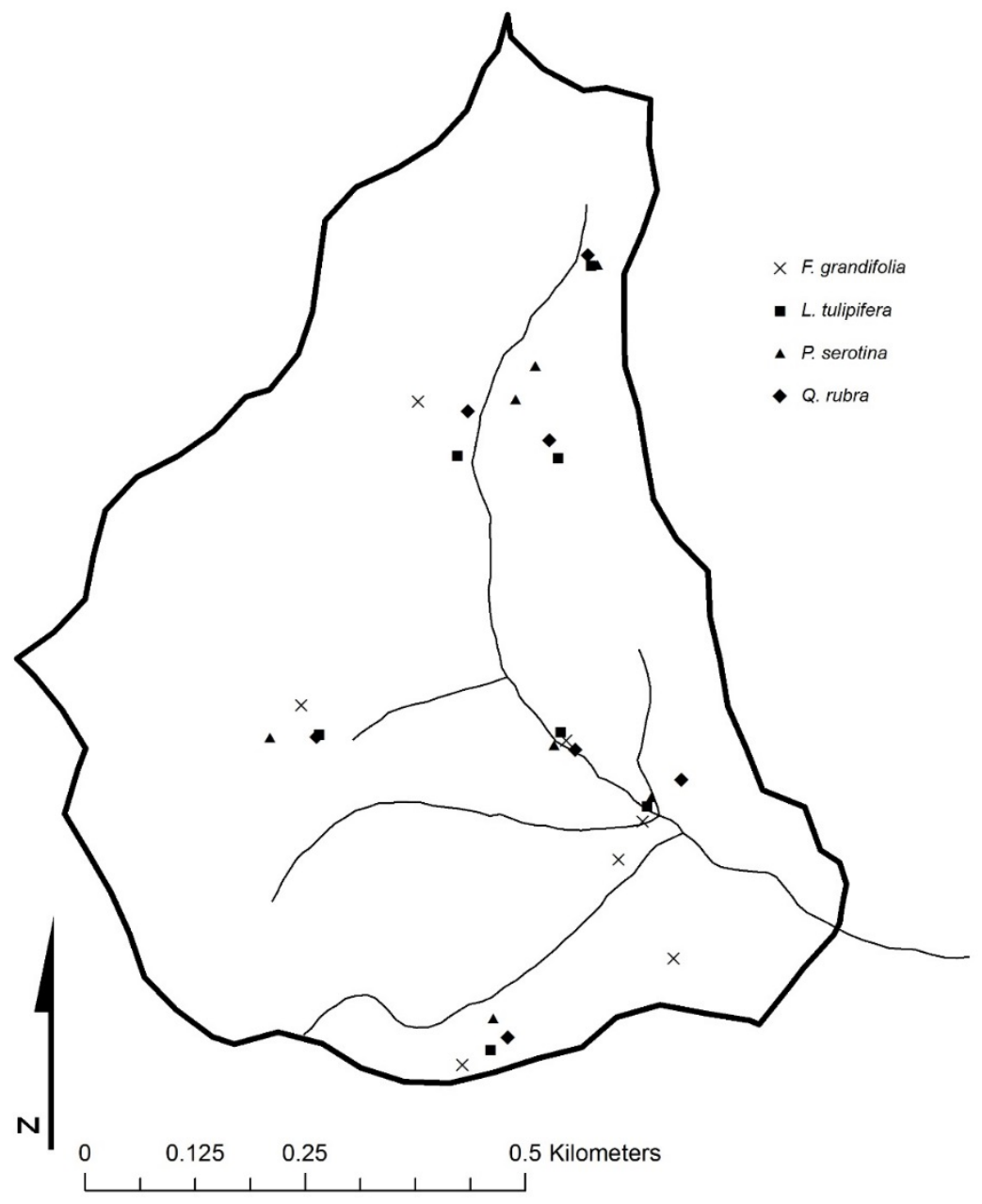

Figure 5-1. Locations of the cored trees in watershed 4 (WS 4) at the Fernow Experimental Forest (FEF). 

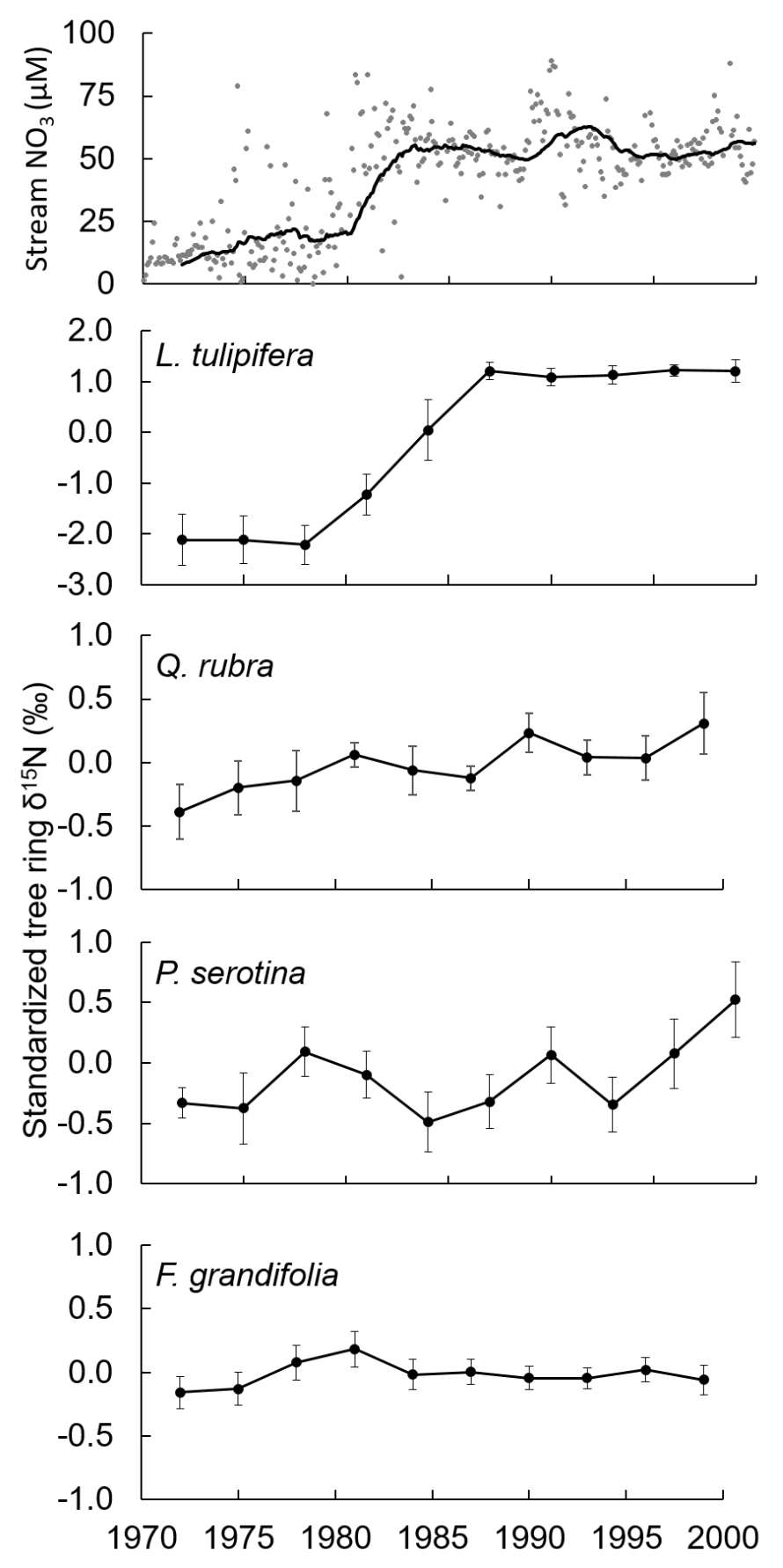

Figure 5-2. Stream water $\mathrm{NO}_{3}$ concentration and tree ring $\delta^{15} \mathrm{~N}$ signature since 1971. The temporal trend in stream water $\mathrm{NO}_{3}$ is visualized using a 3-year running average of the monthly, flow-weighted stream water $\mathrm{NO}_{3}$ concentration. The average tree ring $\delta^{15} \mathrm{~N}(\mathrm{n}=7$ for each species) is shown for each 3-year time segment, 1971-2000. Note the difference in y-axis scale for L. tulipifera. 


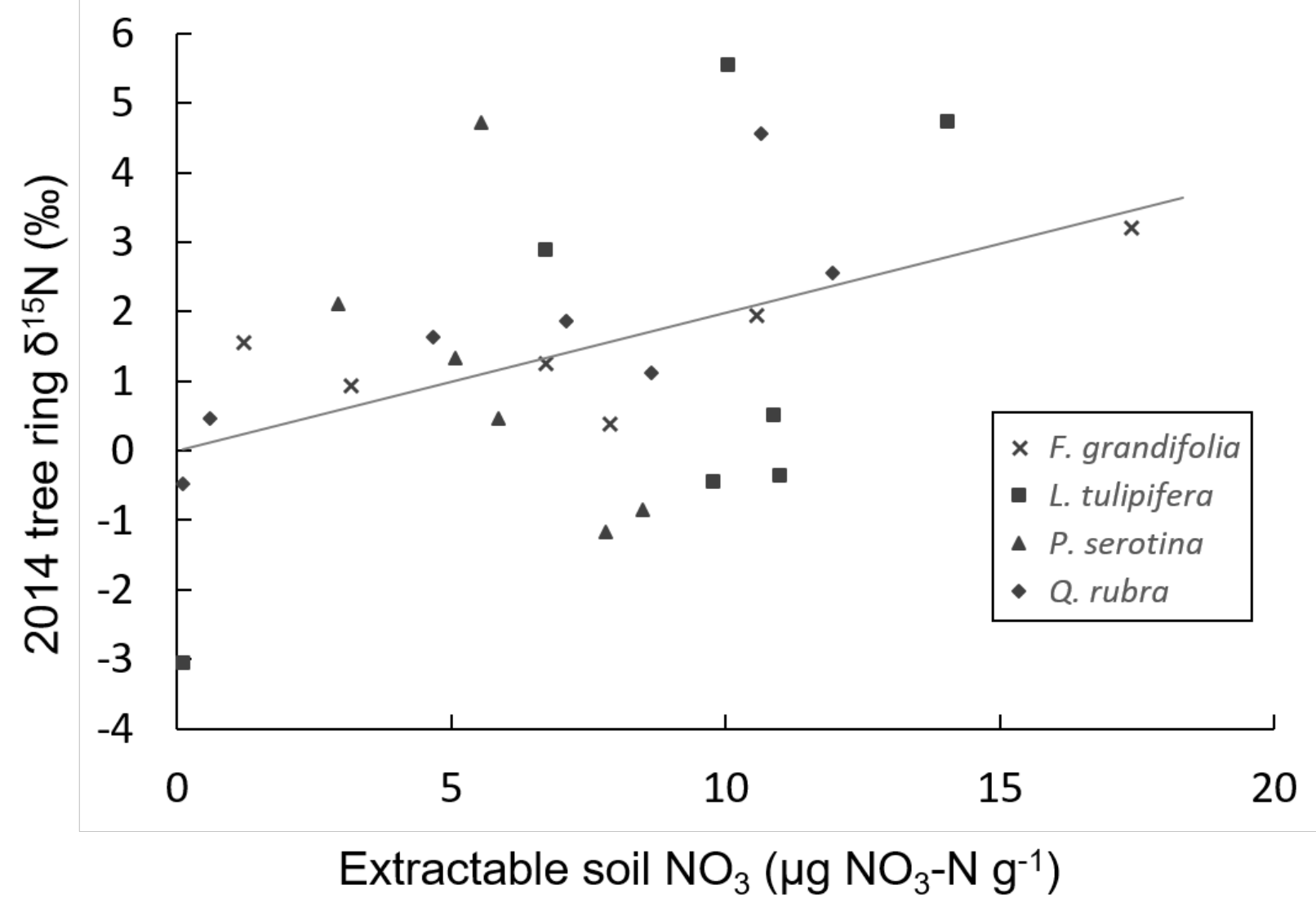

Figure 5-3. Linear relationship between 2014 soil $\mathrm{KCl}$-extractable $\mathrm{NO}_{3}$ and 2014 tree ring $\delta^{15} \mathrm{~N}$ (all species) $\left(\mathrm{R}^{2}=18.3 \%, \mathrm{P}=0.029\right)$. 

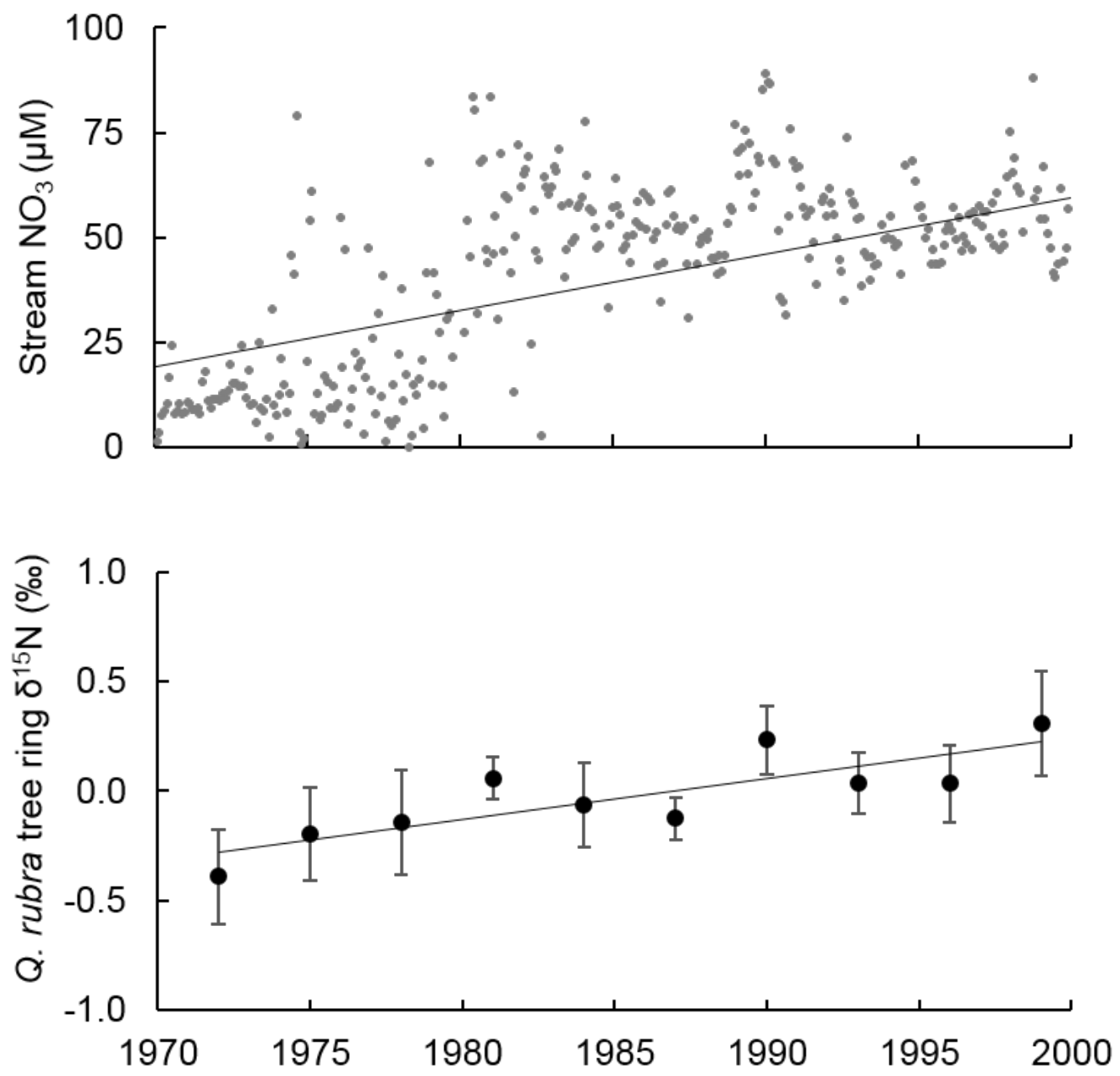

Figure 5-4. Monthly flow-weighted average stream water $\mathrm{NO}_{3}$ concentration $(\mu \mathrm{M})$ and $Q$. rubra standardized tree ring $\delta^{15} \mathrm{~N}(\%)$ from 1970 through 2000. 


\subsection{References}

Aber J, McDowell W, Nadelhoffer K, Magill A, Bernston G, Kamakea M, McNulty S, Currie W, Rustad L, Fernandez I (1998) Nitrogen saturation in temperate forest ecosystems. Bioscience 48:921-934.

Bunn AG (2010) Statistical and visual crossdating in R using the dplR library. Dendrochronologia 28:251-258. doi: 10.1016/j.dendro.2009.12.001

Burnham MB, McNeil BE, Adams MB, Peterjohn WT (2016) The response of tree ring $\delta^{15} \mathrm{~N}$ to whole-watershed urea fertilization at the Fernow Experimental Forest, WV. Biogeochemistry 130:133-145. doi: 10.1007/s10533-016-0248-y

Craine JM, Elmore AJ, Aidar MPM, Bustamante M, Dawson TE, Hobbie EA, Kahmen A, Mack MC, McLauchlan KK, Michelsen A, Nardoto GB, Pardo LH, Peñuelas J, Reich PB, Schuur EAG, Stock WD, Templer PH, Virginia RA, Welker JM, Wright IJ (2009) Global patterns of foliar nitrogen isotopes and their relationships with climate, mycorrhizal fungi, foliar nutrient concentrations, and nitrogen availability. New Phytol 183:980-992. doi: $10.1111 / \mathrm{j} .1469-8137.2009 .02917 . \mathrm{x}$

Edwards P, Helvey J (1991) Long-term ionic increases from a Central Appalachian forested watershed. J Environ Qual 20:250-255.

Elhani S, Guehl J-M, Nys C, Picard J-F, Dupouey J-L (2005) Impact of fertilization on tree-ring $\delta^{15} \mathrm{~N}$ and $\delta^{13} \mathrm{C}$ in beech stands: a retrospective analysis. Tree Physiol 25:1437-1446.

Elhani S, Lema B, Zeller B, Brechet C, Guehl J, Dupouey J (2003) Inter-annual mobility of nitrogen between beech rings: a labelling experiment. Ann For Sci 60:503-508. doi: $10.1051 /$ forest 
Elliott EM, Kendall C, Wankel SD, Burns D a, Boyer EW, Harlin K, Bain DJ, Butler TJ (2007)

Nitrogen isotopes as indicators of $\mathrm{NO}(\mathrm{x})$ source contributions to atmospheric nitrate deposition across the midwestern and northeastern United States. Environ Sci Technol 41:7661-7667.

Elmore AJ, Nelson DM, Craine JM (2016) Earlier springs are causing reduced nitrogen availability in North American eastern deciduous forests. Nat Plants 2:16133. doi: 10.1038/nplants. 2016.133

Falxa-Raymond N, Patterson AE, Schuster WSF, Griffin KL (2012) Oak loss increases foliar nitrogen, $\delta^{15} \mathrm{~N}$ and growth rates of Betula lenta in a northern temperate deciduous forest. Tree Physiol 32:1092-1101. doi: 10.1093/treephys/tps068

Firestone MK, Davidson EA (1989) Microbiologial Basis of $\mathrm{NO}$ and $\mathrm{N}_{2} \mathrm{O}$ production and consumption in soil. In: Andreae MO, Schimel DS (eds) Exchange of Trace Gases between Terrestrial Ecosystems and the Atmosphere. John Wiley \& Sons Ltd., pp 7-21

Galloway J, Dentener F, Capone D, Boyer E, Howarth R, Seitzinger S, Asner G, Cleveland C, Green P, Holland E, Karl D, Michaels A, Porter J, Townsend A, Vorosmarty C (2004) Nitrogen cycles: past, present, and future. Biogeochemistry 70:153-226.

Garten C (1993) Variation in foliar ${ }^{15} \mathrm{~N}$ abundance and the availability of soil nitrogen on Walker Branch Watershed. Ecology 74:2098-2113.

Gerhart LM, McLauchlan KK (2014) Reconstructing terrestrial nutrient cycling using stable nitrogen isotopes in wood. Biogeochemistry 120:1-21. doi: 10.1007/s10533-014-9988-8 
Gilliam FS, Adams MB, Yurish BM (1996) Ecosystem nutrient responses to chronic nitrogen inputs at Fernow Experimental Forest, West Virginia. Can J For Res 26:196-205.

Gilliam FS, Welch NT, Phillips AH, Billmyer JH, Peterjohn WT, Fowler ZK, Walter CA, Burnham MB, May JD, Adams MB (2016) Twenty-five-year response of the herbaceous layer of a temperate hardwood forest to elevated nitrogen deposition. Ecosphere 7:e01250. doi: $10.1002 / \mathrm{ecs} 2.1250$

Hart SC, Classen AT (2003) Potential for assessing long-term dynamics in soil nitrogen availability from variations in $\delta^{15} \mathrm{~N}$ of tree rings. Isotopes Environ Health Stud 39:15-28. doi: $10.1080 / 1025601031000102206$

Hietz P, Turner BL, Wanek W, Richter A, Nock CA, Wright SJ (2011) Long-Term Change in the Nitrogen Cycle of Tropical Forests. Science (80- ) 334:664-666. doi: 10.1126/science. 1211979

Kochenderfer JN (2006) Fernow and the Appalachian Hardwood Region. In: Adams M, DeWalle D, Hom J (eds) The Fernow Watershed Acidification Study. Springer, Dordrecht, pp 17-39

Lloyd AB, Sheaffe MJ (1973) Urease activity in soils. Plant Soil 39:71-80. doi: 10.1007/BF00018046

Lovett GM, Goodale CL (2011) A new conceptual model of nitrogen saturation based on experimental nitrogen addition to an oak forest. Ecosystems 14:615-631. doi: $10.1007 / \mathrm{s} 10021-011-9432-\mathrm{z}$ 
May JD, Burdette SB, Gilliam FS, Adams MB (2005) Interspecific divergence in foliar nutrient dynamics and stem growth in a temperate forest in response to chronic nitrogen inputs. Can J For Res 35:1023-1030. doi: 10.1139/x05-036

McLauchlan KK, Craine JM (2012) Species-specific trajectories of nitrogen isotopes in Indiana hardwood forests, USA. Biogeosciences 9:867-874. doi: 10.5194/bgd-8-5935-2011

McLauchlan KK, Gerhart LM, Battles JJ, Craine JM, Elmore AJ, Higuera PE, Mack MC, McNeil BE, Nelson DM, Pederson N, Perakis SS (2017) Centennial-scale reductions in nitrogen availability in temperate forests of the United States. Sci Rep 7:7856. doi: $10.1038 / \mathrm{s} 41598-017-08170-\mathrm{z}$

Mnich ME, Houlton BZ (2015) Evidence for a uniformly small isotope effect of nitrogen leaching loss: results from disturbed ecosystems in seasonally dry climates. Oecologia 181:323-333. doi: 10.1007/s00442-015-3433-0

Pardo LH, Nadelhoffer KJ (2012) Using nitrogen isotope ratios to assess terrestrial ecosystems at regional and global scales. In: West JB, Bowen GJ, Dawson TE, Tu KP (eds) Isoscapes. Springer Netherlands, Dordrecht, pp 221-249

Pardo LH, Templer PH, Goodale CL, Duke S, Groffman PM, Adams MB, Boeckx P, Boggs J, Campbell J, Colman B, Compton J, Emmett B, Gundersen P, Kjønaas J, Lovett G, Mack M, Magill A, Mbila M, Mitchell MJ, McGee G, McNulty S, Nadelhoffer K, Ollinger S, Ross D, Rueth H, Rustad L, Schaberg P, Schiff S, Schleppi P, Spoelstra J, Wessel W (2006) Regional assessment of $\mathrm{N}$ saturation using foliar and $\operatorname{root} \delta^{15} \mathrm{~N}$. Biogeochemistry 80:143171. doi: $10.1007 / \mathrm{s} 10533-006-9015-9$ 
Patric J, Smith D (1978) Some effects of urea fertilization on a forested watershed in West Virginia. In: Proceedings 2nd Central Hardwood Forest Conference. West Lafayette, IN, pp $210-227$

Peterjohn WT, Adams MB, Gilliam FS (1996) Symptoms of nitrogen saturation in two central Appalachian hardwood forest ecosystems. Biogeochemistry 35:507-522.

Robinson D (2001) $\delta^{15} \mathrm{~N}$ as an integrator of the nitrogen cycle. Trends Ecol Evol 16:153-162.

Savard MM, Bégin C, Smirnoff A, Marion J, Rioux-Paquette E (2009) Tree-ring nitrogen isotopes reflect anthropogenic NOx emissions and climatic effects. Environ Sci Technol 43:604-9.

Smith KR, Mathias JM, McNeil BE, Peterjohn WT, Thomas RB (2016) Site-level importance of broadleaf deciduous trees outweighs the legacy of high nitrogen $(\mathrm{N})$ deposition on ecosystem N status of Central Appalachian red spruce forests. Plant Soil 408:343-356. doi: $10.1007 / \mathrm{s} 11104-016-2940-\mathrm{z}$

Templer PH, Arthur MA, Lovett GM, Weathers KC (2007) Plant and soil natural abundance $\delta^{15} \mathrm{~N}$ : Indicators of relative rates of nitrogen cycling in temperate forest ecosystems. Oecologia 153:399-406. doi: 10.1007/s00442-007-0746-7

Wallenstein M, Peterjohn W, Schlesinger W (2006) N fertilization effects on denitrification and $\mathrm{N}$ cycling in an aggrading forest. Ecol Appl 16:2168-2176.

Weier KL, Doran JW, Power JF, Walters DT (1993) Denitrification and the dinitrogen/nitrous oxide ratio as affected by soil water, available carbon, and nitrate. Soil Sci Soc Am J 57:6672. 
Wexler SK, Goodale CL, McGuire KJ, Bailey SW, Groffman PM (2014) Isotopic signals of summer denitrification in a northern hardwood forested catchment. Proc Natl Acad Sci U S A 111:16413-8. doi: 10.1073/pnas.1404321111 
Chapter 6. Conclusion: Moving towards an improved understanding of $\mathrm{N}$ supply and demand in forests 


\subsection{Summary of results}

For my dissertation I took advantage of long-term records of $\mathrm{N}$ cycling in four watersheds at the Fernow Experimental Forest (FEF) in order to: 1) determine if the species composition in a forested watershed (WS 4) has shifted towards trees with a reduced uptake of $\mathrm{NO}_{3}$, thereby contributing to greater $\mathrm{NO}_{3}$ export in stream water, 2) determine if the experimental acidification of WS 3 exposed tree roots to higher levels of free, unchelated $\mathrm{Al}^{3+}$, and whether an increased exposure could change the relative uptake of different forms of mineral $\mathrm{N}$ by trees in ways that could alter stream water $\mathrm{NO}_{3}$ export, 3) examine how effectively the tree ring $\delta^{15} \mathrm{~N}$ of four temperate broadleaf deciduous tree species records an experimentally induced change in $\mathrm{N}$ retention caused by a large, one-time addition of urea, and 4) assess the ability of tree ring $\delta^{15} \mathrm{~N}$ to respond to increased soil $\mathrm{NO}_{3}$ supply and detect an increase in stream nitrate concentrations that is documented in the long-term stream water $\mathrm{NO}_{3}$ records for WS 4 .

Contrary to my initial expectation, I found that six temperate broadleaf tree species did not differ in their relative uptake of $\mathrm{NH}_{4}$ versus $\mathrm{NO}_{3}$. Also, all species took up similar amounts of the two mineral $\mathrm{N}$ forms, with an average of $59 \%$ of $\mathrm{N}$ taken up as $\mathrm{NO}_{3}\left(0.074 \pm 0.02 \mu \mathrm{mol}{ }^{15} \mathrm{~N} \mathrm{~g}^{-1} \mathrm{hr}^{-1}\right.$ from the labeled $\mathrm{N}$ pool). Particularly surprising was the finding that $A$. saccharum took up a significant amount of $\mathrm{NO}_{3}$, since prior studies, using different methods, indicate that this species relies mostly on $\mathrm{NH}_{4}$ (Rothstein et al. 1996; BassiriRad et al. 1999; Lovett and Mitchell 2004; Templer and Dawson 2004; Eddy et al. 2008). Comparing my N uptake results with long-term records of tree species composition, I found that the composition of trees did not shift towards species with lower $\mathrm{NO}_{3}$ demand in FEF WS 4. In fact, the overall uptake of $\mathrm{N}$ by trees in the watershed increased through time, driven mainly by the rate of increase in total basal area within 
the watershed. Although changes in stand $\mathrm{N}$ demand did not account for increases in stream water $\mathrm{NO}_{3}$ discharge, it is likely that a higher $A$. saccharum importance value contributed to greater soil nitrification ( $\mathrm{N}$ supply) in the parts of the watershed that were associated with the observed increase in stream $\mathrm{NO}_{3}$ (Christ et al. 2002; Lovett and Mitchell 2004; Peterjohn et al. 2015). To demonstrate the potential impact this could have on stream water $\mathrm{NO}_{3}$ discharge, $\mathrm{I}$ estimated that higher $A$. saccharum importance in 2001, compared to 1959 , could result in an additional $3.9 \mathrm{~kg} \mathrm{~N} \mathrm{ha}^{-1} \mathrm{yr}^{-1}$ being available for leaching into stream water, illustrating the importance of species composition in soil $\mathrm{NO}_{3}$ supply and, consequently, $\mathrm{N}$ leaching from the watershed.

While species did not differ in their proportion of $\mathrm{N}$ taken up as $\mathrm{NO}_{3}$ versus $\mathrm{NH}_{4}$, soluble soil $\mathrm{Al}^{3+}$, a consequence of acid deposition, does appear to alter the $\mathrm{NO}_{3}$ demand by trees. The presence of soil $\mathrm{Al}^{3+}$ reduced the proportion of $\mathrm{N}$ taken up as $\mathrm{NO}_{3}$ from $59 \%$ to $44.6 \%(0.074$ to $0.065 \mu \mathrm{mol}{ }^{15} \mathrm{~N} \mathrm{~g}^{-1} \mathrm{hr}^{-1}$ from the labeled $\mathrm{N}$ pool), and this reduction was consistent among all species examined. This finding extends past laboratory results, using herbaceous species, to overstory trees growing in field conditions. At the FEF, experimental fertilization and acidification in WS 3 significantly increased soil $\mathrm{Al}^{3+}$ levels. Therefore, it is likely that the acidification-induced increase in soil $\mathrm{Al}^{3+}$ reduced the $\mathrm{NO}_{3}$ demand by trees, and contributed to increased stream water $\mathrm{NO}_{3}$ discharge (Figure 1-3). Indeed, I estimate that enhanced $\mathrm{Al}^{3+}$ solubility in WS 3 could account for up to $76 \%$ of the increase in stream water $\mathrm{NO}_{3}$ discharge. 
When $\mathrm{N}$ supply exceeds the stand demand, the tree ring $\delta^{15} \mathrm{~N}$ of some species increases, which could be used as a proxy for changes in watershed $\mathrm{N}$ cycling. I found evidence for this effect in the tree ring $\delta^{15} \mathrm{~N}$ record of three species in FEF WS 1, which was fertilized with urea in 1971. Each species that responded to the large, one-time input of N (Q. rubra, P. serotina, and $F$. grandifolia) differed slightly in its response, but detected the onset of $\mathrm{N}$ cycle disturbance within 1-3 years, and we found some evidence of inward mobility of $\mathrm{N}$ compounds within the tree for Q. rubra. However, the tree ring $\delta^{15} \mathrm{~N}$ of these species did not capture the decline of stream water $\mathrm{NO}_{3}$ in the years following urea fertilization, probably due to retranslocation and potentially outward mobility of $\mathrm{N}$ within the tree, and the continued cycling of ${ }^{15} \mathrm{~N}$ within the watershed (Figure 6-1). While the fourth species I studied, L. tulipifera, did not respond to the fertilization event, its tree ring $\delta^{15} \mathrm{~N}$ increased around 1980, a time which coincides with an $\mathrm{N}$ saturation signal due to chronic $\mathrm{N}$ deposition in WS 1 and WS 4 . Thus, tree ring $\delta^{15} \mathrm{~N}$ does not offer the precise annual resolution typical of dendrochronological studies, but is a useful tool to study the general timing of $\mathrm{N}$ cycle disturbance that causes higher supply vs. demand on a decadal time scale.

In the absence of a pulse disturbance in the $\mathrm{N}$ cycle, the $\delta^{15} \mathrm{~N}$ of tree rings provides some information about long-term changes in $\mathrm{N}$ supply via deposition relative to watershed demand, but enough uncertainty remains to preclude its widespread implementation. In FEF WS 4, $L$. tulipifera and $Q$. rubra tree ring $\delta^{15} \mathrm{~N}$, but not that of $P$. serotina or $F$. grandifolia, correlated with stream water $\mathrm{NO}_{3}$ concentration from 1970 to 2000. L. tulipifera was particularly effective at capturing the $\mathrm{N}$ saturation-induced increase in stream water $\mathrm{NO}_{3}$ from 1978 to 1981 (Figure 12), while Q. rubra showed more of a long, general increasing trend in tree ring $\delta^{15} \mathrm{~N}$. Soil N 
pools and transformation rates impacted the 2014 tree ring $\delta^{15} \mathrm{~N}$, and were associated with the correlations between tree ring $\delta^{15} \mathrm{~N}$ and stream $\mathrm{NO}_{3}$ concentration, for the same two species, but not for P. serotina or F. grandifolia. Surrounding stand dynamics and potential mobility of N within trees may impede the ability of $F$. grandifolia and $P$. serotina to record $\mathrm{N}$ saturation signals. Thus, two major deciduous tree species, L. tulipifera and Q. rubra, record $\mathrm{N}$ saturation, but with different sensitivity. Overall, there is enough response of tree ring $\delta^{15} \mathrm{~N}$ to $\mathrm{N}$ cycling to have some utility, but there is enough variability to preclude its widespread application until more is known about the mechanisms that govern wood $\delta^{15} \mathrm{~N}$ variation.

\subsection{Long-term records at the FEF and beyond}

It was only possible to observe the effects of $\mathrm{Al}^{3+}$ and species composition on the $\mathrm{N}$ cycle due to the existence of long-term records at the FEF. Many of the controls on the fate of added N described by Lovett and Goodale (2011) can only be rigorously examined when long-term records of $\mathrm{N}$ cycling are available. Thus, the importance of long-term $\mathrm{N}$ cycling records has led to the increased measurement of tree ring $\delta^{15} \mathrm{~N}$ as a proxy for $\mathrm{N}$ supply and demand dynamics (Gerhart and McLauchlan 2014), but my results demonstrate that there remains a significant amount of uncertainty surrounding its usefulness (Chapter 4, Chapter 5). However, at least at the FEF, where the tree ring $\delta^{15} \mathrm{~N}$ can be validated against stream chemistry records, it can be used to extend existing records back in time for several decades (Chapter 4). In addition, other studies have detected coherent $\delta^{15} \mathrm{~N}$ signals when large data sets are used for wood samples, or when other types of plant tissue are examined. So, despite remaining uncertainties, there is likely valuable information stored in the $\delta^{15} \mathrm{~N}$ isotopic signature. However, the high variability between the ability of different species to record the same $\mathrm{N}$ cycle dynamics in a single watershed 
illustrates the need for a greater understanding the mechanisms that control the storage of $\mathrm{N}$ in wood and its $\delta^{15} \mathrm{~N}$ signature. Given the utility of long-term records of $\mathrm{N}$ cycling, and the prevalence of forested ecosystems impacted by chronic $\mathrm{N}$ deposition, tree ring $\delta{ }^{15} \mathrm{~N}$ offers the possibility of expanding long-term records when these mechanisms are better understood.

\subsection{Towards an improved understanding of watershed $\mathrm{NO}_{3}$ demand and production}

In a revised framework of $\mathrm{N}$ saturation, Lovett and Goodale (2011) outlined a variety of controls over the flows of $\mathrm{N}$ in forest ecosystems, including the potential for plant $\mathrm{N}$ demand and species composition to affect the fate of added N. Through my work, I have provided empirical evidence for the impact of soil acidity on plant $\mathrm{N}$ demand (Chapter 3). An increase in soil acidity accompanies chronic $\mathrm{N}$ deposition (Driscoll et al. 2001), and this impedes plant $\mathrm{NO}_{3}$ uptake due to increased $\mathrm{Al}^{3+}$ solubility in the soil. In acidified soils, the flow of $\mathrm{NO}_{3}$ into plants would be hindered, leaving more $\mathrm{N}$ to move into other compartments or out of the system. Since $\mathrm{Al}^{3+}$ impeded the uptake of $\mathrm{NO}_{3}$, this mineral $\mathrm{N}$ pool accumulates, and $\mathrm{NO}_{3}$ is the primary mobile form of $\mathrm{N}$ that leaches into stream water. Thus, I suggest that we consider the potential for soil acidity to affect not only the flow of total $\mathrm{N}$ into plants, but also the flows of $\mathrm{NH}_{4}$ and $\mathrm{NO}_{3}$ (Figure 6-1), since they have different immediate fates in the $\mathrm{N}$ cycle.

While I found that long-term species change does not exert much influence on total stand $\mathrm{N}$ or $\mathrm{NO}_{3}$ demand in FEF WS 4 (Chapter 2), other effects of species composition should be considered. Lovett et al. (2004) and Peterjohn et al. (2015) showed strong evidence of the potential for species composition to affect $\mathrm{N}$ cycling in forests. Using long-term records of both 
stand composition and $\mathrm{N}$ cycling at the FEF, as well as measurements of how A. saccharum affects soil $\mathrm{NO}_{3}$ production in the $\mathrm{FEF}$ (Christ et al. 2002), I was able to estimate the magnitude to which a change towards higher $A$. saccharum abundance impacts $\mathrm{NO}_{3}$ leaching through time. This demonstrates a plant-mediated influence on the $\mathrm{N}$ cycle through enhanced $\mathrm{NO}_{3}$ production in the soil (Figure 6-1). Therefore, it is important to address the potential effects of species change when studying $\mathrm{N}$ supply and demand dynamics in forests.

The use of long-term records at the FEF allowed me to improve our understanding of how internal processes affect the outputs of $\mathrm{N}$ from forested ecosystems experiencing chronic $\mathrm{N}$ deposition. Forests across the northeastern United States received high N supply throughout the second half of the $20^{\text {th }}$ century, in some enough to overcome ecosystem $\mathrm{N}$ demand and result in $\mathrm{N}$-saturation (Aber et al. 1998). However, many factors control the internal cycling of added $\mathrm{N}$, and increased $\mathrm{N}$ supply does not always directly cause an increased discharge of $\mathrm{N}$ into streams. Species composition and acidity were suggested as potential controls on the flow of deposited $\mathrm{N}$ through the ecosystem by Lovett and Goodale (2011), and I have demonstrated two mechanisms through which these controls occur: changes in species composition that cause greater soil $\mathrm{N}$ supply within the ecosystem, and $\mathrm{Al}^{3+}$-mediated reductions in plant $\mathrm{NO}_{3}$ demand. Both have significant impacts on stream water $\mathrm{NO}_{3}$ discharge from forested watersheds. Thus, in addition to our current knowledge of supply-side effects on ecosystem $\mathrm{N}$ cycling, I suggest that future studies further elucidate the impacts of ecosystem demand on forest $\mathrm{N}$ discharge, because forest $\mathrm{N}$ demand has a substantial impact on ecosystem $\mathrm{N}$ loss. 


\subsection{Tables and Figures}

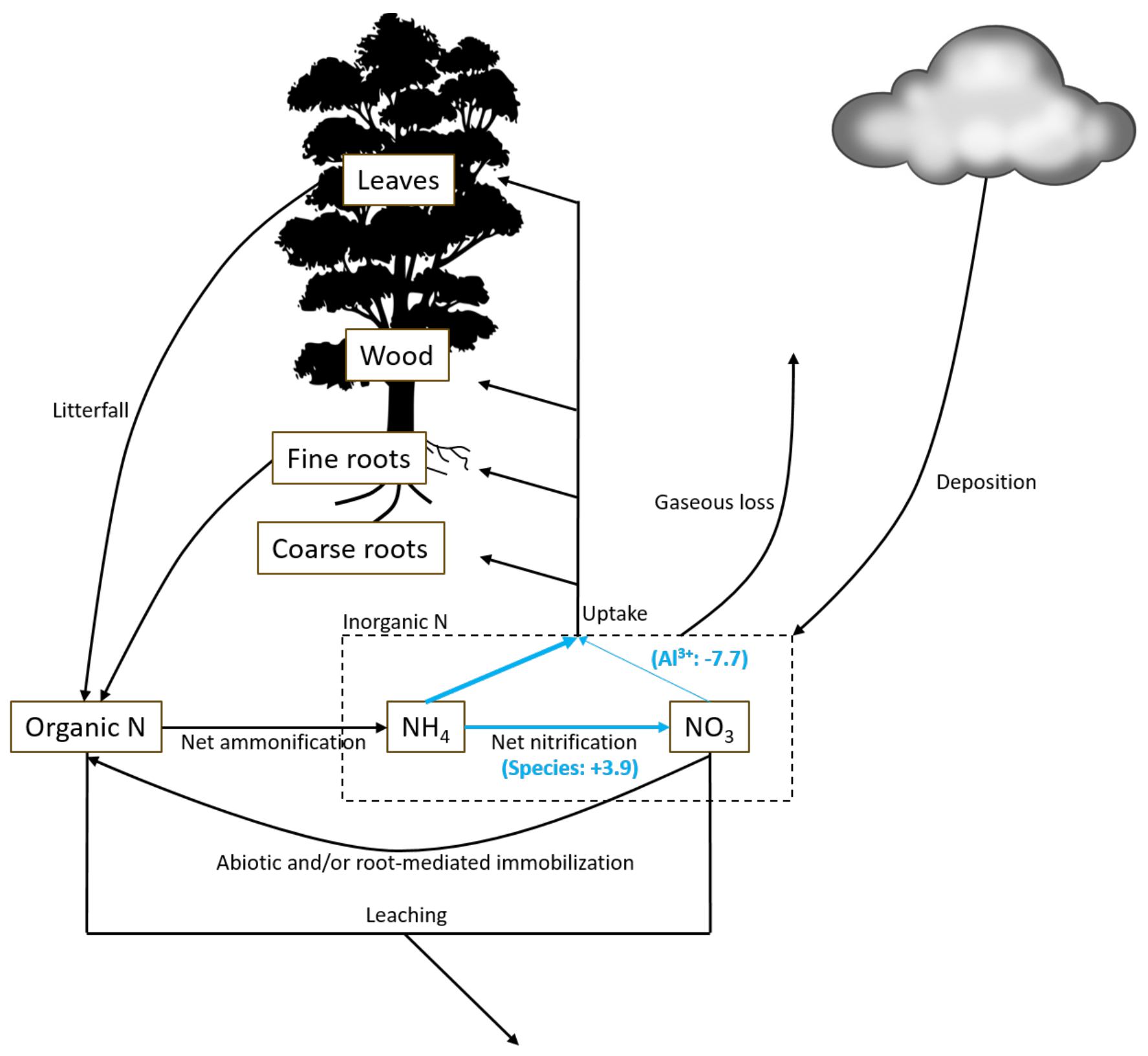

Figure 6-1. The forest $\mathrm{N}$ cycle with the estimated impacts of species composition change and increased $\mathrm{Al}^{3+}$ on $\mathrm{NO}_{3}$ supply and demand at the FEF. 


\subsection{References}

Aber J, McDowell W, Nadelhoffer K, Magill A, Bernston G, Kamakea M, McNulty S, Currie W, Rustad L, Fernandez I (1998) Nitrogen saturation in temperate forest ecosystems. Bioscience 48:921-934.

Aber JD, Nadelhoffer KJ, Steudler P, Melillo JM (1989) Nitrogen saturation in northern forest ecosystems. Bioscience 39:378-386.

BassiriRad H, Prior S, Norby R, Rogers H (1999) A field method of determining $\mathrm{NH}_{4}^{+}$and $\mathrm{NO}_{3}{ }^{-}$ uptake kinetics in intact roots: Effects of $\mathrm{CO}_{2}$ enrichment on trees and crop species. Plant Soil 217:195-204.

Bukata AR, Kyser TK (2007) Carbon and nitrogen isotope variations in tree-rings as records of perturbations in regional carbon and nitrogen cycles. Environ Sci Technol 41:1331-1338.

Calba H, Jaillard B (1997) Effect of aluminum on ion uptake and $\mathrm{H}^{+}$release by maize. New Phytol 137:607-616.

Campbell JL, Hornbeck JW, Mitchell MJ, Adams MB, Castro MS, Driscoll CT, Kahl JS, Kochenderfer JN, Likens GE, Lynch JA, Murdoch PS, Nelson SJ, Shanley JB (2004) Inputoutput budgets of inorganic nitrogen for 24 forest watersheds in the northeastern United States: A review. Water Air Soil Pollut 151:373-396.

Chen C, Li J, Wang G, Shi M (2017) Accounting for the effect of temperature in clarifying the response of foliar nitrogen isotope ratios to atmospheric nitrogen deposition. Sci Total Environ 609:1295-1302. doi: 10.1016/j.scitotenv.2017.06.088 
Choi W-J, Lee S-M, Chang SX, Ro H-M (2005) Variations of $\delta^{13} \mathrm{C}$ and $\delta^{15} \mathrm{~N}$ in Pinus densiflora tree-rings and their relationship to environment changes in eastern Korea. Water Air Soil Pollut 164:173-187.

Christ M, Peterjohn W, Cumming J, Adams M (2002) Nitrification potentials and landscape, soil and vegetation characteristics in two Central Appalachian watersheds differing in NO3export. For Ecol Manage 159:145-158.

Delhaize E, Ryan P (1995) Aluminum toxicity and tolerance in plants. Plant Physiol 107:315321.

Douglass AE (1920) Evidence of climatic effects in the annual rings of trees. Ecology 1:24-32.

Driscoll CT, Lawrence GB, Bulger AJ, Butler TJ, Cronan CS, Eagar C, Lambert KF, Likens GE, Stoddard JL, Weathers KC (2001) Acidic deposition in the northeastern United States: Sources and inputs, ecosystems effects, and management strategies. Bioscience 51:180198. doi: 10.1641/0006-3568(2001)051[0180:ADITNU]2.0.CO;2

Durieux R, Jackson W, Kamprath E, Moll R (1993) Inhibition of nitrate uptake by aluminum in maize. Plant Soil 151:97-104.

Eddy WC, Zak DR, Holmes WE, Pregitzer KS (2008) Chronic Atmospheric $\mathrm{NO}_{3}{ }^{-}$Deposition Does Not Induce $\mathrm{NO}_{3}{ }^{-}$Use by Acer saccharum Marsh. Ecosystems 11:469-477. doi: $10.1007 / \mathrm{s} 10021-008-9134-3$

Falxa-Raymond N, Patterson AE, Schuster WSF, Griffin KL (2012) Oak loss increases foliar nitrogen, $\delta^{15} \mathrm{~N}$ and growth rates of Betula lenta in a northern temperate deciduous forest. Tree Physiol 32:1092-1101. doi: 10.1093/treephys/tps068 
Fenn M, Baron J, Allen E, Rueth H, Nydick K, Geiser L, Bowman W, Sickman J, Meixner T, Johnson D, Neitlich P (2003) Ecological effects of nitrogen deposition in the western United States. Bioscience 53:404-420. doi: 10.1641/0006-3568(2003)053

Galloway J, Dentener F, Capone D, Boyer E, Howarth R, Seitzinger S, Asner G, Cleveland C, Green P, Holland E, Karl D, Michaels A, Porter J, Townsend A, Vorosmarty C (2004) Nitrogen cycles: past, present, and future. Biogeochemistry 70:153-226.

Gerhart LM, McLauchlan KK (2014) Reconstructing terrestrial nutrient cycling using stable nitrogen isotopes in wood. Biogeochemistry 120:1-21. doi: 10.1007/s10533-014-9988-8

Gundersen P, Rasmussen L (1990) Nitrification in forest soils: Effects from nitrogen deposition on soil acidification and aluminum release. Rev Environ Contam Toxicol 113:1-45. doi: $10.1177 / 0192513 X 12437708$

Hogberg P (1997) 15N natural abundance in soil-plant systems. New Phytol 137:179-203.

Jarvis SC, Hatch DJ (1986) The effects of low concentrations of aluminum on the growth and uptake of nitrate-N by white clover. Plant Soil 95:43-55.

Jaworski NA, Howarth RW, Hetling LJ (1997) Atmospheric Deposition of Nitrogen Oxides onto the Landscape Contributes to Coastal Eutrophication in the Northeast United States. Environ Sci Technol 31:1995-2004. doi: 10.1021/es960803f

Kochenderfer JN (2006) Fernow and the Appalachian Hardwood Region. In: Adams M, DeWalle D, Hom J (eds) The Fernow Watershed Acidification Study. Springer, Dordrecht, pp 17-39 
LeBauer DS, Treseder KK (2008) Nitrogen Limitation of Net Primary Productivity in Terrestrial Ecosystems Is Globally Distributed. Ecology 89:371-379.

Lovett G, Mitchell M (2004) Sugar maple and nitrogen cycling in the forests of Eastern North America. Front Ecol Environ 2:81-88.

Lovett GM, Goodale CL (2011) A new conceptual model of nitrogen saturation based on experimental nitrogen addition to an oak forest. Ecosystems 14:615-631. doi: $10.1007 / \mathrm{s} 10021-011-9432-\mathrm{z}$

Lovett GM, Weathers KC, Arthur MA, Schultz JC (2004) Nitrogen cycling in a northern hardwood forest: Do species matter? Biogeochemistry 67:289-308. doi: 10.1023/B:BIOG.0000015786.65466.f5

McLauchlan KK, Craine JM (2012) Species-specific trajectories of nitrogen isotopes in Indiana hardwood forests, USA. Biogeosciences 9:867-874. doi: 10.5194/bgd-8-5935-2011

McLauchlan KK, Gerhart LM, Battles JJ, Craine JM, Elmore AJ, Higuera PE, Mack MC, McNeil BE, Nelson DM, Pederson N, Perakis SS (2017) Centennial-scale reductions in nitrogen availability in temperate forests of the United States. Sci Rep 7:7856. doi: $10.1038 / \mathrm{s} 41598-017-08170-\mathrm{Z}$

Peterjohn WT, Adams MB, Gilliam FS (1996) Symptoms of nitrogen saturation in two central Appalachian hardwood forest ecosystems. Biogeochemistry 35:507-522.

Peterjohn WT, Foster CJ, Christ MJ, Adams MB (1999) Patterns of nitrogen availability within a forested watershed exhibiting symptoms of nitrogen saturation. For Ecol Manage 119:247257. doi: $10.1016 / \mathrm{S} 0378-1127(98) 00526-\mathrm{X}$ 
Peterjohn WT, Harlacher MA, Christ MJ, Adams MB (2015) Testing associations between tree species and nitrate availability: Do consistent patterns exist across spatial scales? For Ecol Manage 358:335-343. doi: 10.1016/j.foreco.2015.09.018

Poulson S, Chamberlain C, Friedland A (1995) Nitrogen isotope variation of tree rings as a potential indicator of environmental change. Chem Geol 125:307-315.

Reinhart K, Eschner A, Trimble G (1963) Effect on streamflow of four forest practices in the mountains of West Virginia. US Forest Service Research Paper NE-1, Northern Forest Experiment Station, Upper Darby, PA.

Robinson D (2001) $\delta^{15} \mathrm{~N}$ as an integrator of the nitrogen cycle. Trends Ecol Evol 16:153-162.

Rose L, Sebestyen S, Elliott E, Koba K (2015) Drivers of atmospheric nitrate processing and export in forested catchments. Water Resour Res 51:1333-1352. doi: 10.1002/2014WR015716

Rothstein DE, Zak DR, Pregitzer KS, Url S, Zak R (1996) Nitrate deposition in northern hardwood forests and the nitrogen metabolism of Acer saccharum Marsh. Oecologia 108:338-344.

Savard MM, Bégin C, Smirnoff A, Marion J, Rioux-Paquette E (2009) Tree-ring nitrogen isotopes reflect anthropogenic NOx emissions and climatic effects. Environ Sci Technol 43:604-9.

Schuler T, Gillespie A (2000) Temporal patterns of woody species diversity in a central Appalachian forest from 1856 to 1997. J Torrey Bot Soc 127:149-161. 
Sun F, Kuang Y, Wen D, Xu Z, Li J, Zuo W, Hou E (2010) Long-term tree growth rate, water use efficiency, and tree ring nitrogen isotope composition of Pinus massoniana L. in response to global climate change and local nitrogen deposition in Southern China. J Soils Sediments 10:1453-1465. doi: 10.1007/s11368-010-0249-8

Templer PH, Dawson TE (2004) Nitrogen uptake by four tree species of the Catskill Mountains, New York: implications for forest N dynamics. Plant Soil 262:251-261. doi: 10.1023/B:PLSO.0000037047.16616.98

Trimble G (1977) A history of the Fernow Experimental Forest and the Parsons Timber and Watershed Laboratory.

Vitousek P, Howarth R (1991) Nitrogen limitation on land and in the sea: how can it occur? Biogeochemistry 13:87-115. 
Appendix A. Supplementary Tables 
Table A-1. 3-way ANOVA results for soil Al analysis by Al form, soil fraction, and watershed.

\begin{tabular}{lcc}
\hline \hline Model effect & F-value & P-value \\
\hline Al form (chelated vs. $\mathrm{Al}^{3+}$ ) & 136.0 & $<0.001$ \\
Watershed (WS) & 24.5 & $<0.001$ \\
Soil fraction & 0.9 & 0.409 \\
Al form x WS & 13.3 & $<0.001$ \\
Al form x Soil fraction & 10.0 & $<0.001$ \\
Watershed x Soil fraction & 22.8 & $<0.001$ \\
Al form x WS x Soil fraction & 6.1 & 0.003 \\
\hline
\end{tabular}

